\title{
OS MECANISMOS DE DEMOCRACIA DIRETA NO CONSTITUCIONALISMO IBERO-AMERICANO: ANÁLISE COMPARADA
}

\author{
Tese de Doutorado \\ Regime de Dupla Titulação \\ Orientadoras: \\ Profa. Dra. Monica Herman Salem Caggiano (USP) \\ Profa. Dra. Pilar Jiménez Tello (USAL) \\ UNIVERSIDADE DE SÃO PAULO \\ FACULDADE DE DIREITO \\ SÃO PAULO-SP \\ 2017 \\ UNIVERSIDAD DE SALAMANCA \\ FACULTAD DE DERECHO \\ SALAMANCA \\ 2017
}




\title{
OS MECANISMOS DE DEMOCRACIA DIRETA NO CONSTITUCIONALISMO IBERO-AMERICANO: ANÁLISE COMPARADA
}

Tese apresentada à Banca Examinadora do Programa de Pós-Graduação em Direito, da Faculdade de Direito da Universidade de São Paulo, como exigência parcial para obtenção do título de Doutor em Direito, na área de concentração Direito do Estado, em regime de dupla titulação com a Faculdade de Direito da Universidade de Salamanca, sob a orientação da Professora Dra. Monica Herman Salem Caggiano (USP) e da Professora Dra. Pilar Jiménez Tello (USAL).

\author{
UNIVERSIDADE DE SÃO PAULO \\ FACULDADE DE DIREITO \\ SÃO PAULO-SP \\ 2017 \\ UNIVERSIDAD DE SALAMANCA \\ FACULTAD DE DERECHO \\ SALAMANCA \\ 2017
}




\section{Catalogação da Publicação \\ Serviço de Biblioteca e Documentação Faculdade de Direito da Universidade de São Paulo}

de Oliveira Soares, Alessandro

Os mecanismos de democracia direta no constitucionalismo ibero-americano: análise comparada / Alessandro de Oliveira Soares ; orientadora Monica Herman Salem Caggiano; Pilar Jiménez Tello - São Paulo, 2017. 706

Tese (Doutorado - Programa de Pós-Graduação em Direito do Estado) - Faculdade de Direito, Universidade de São Paulo, 2017.

1. Democracia. 2. Democracia Direta. 3. Referendo. 4. Plebiscito. 5. Revogação de Mandato. I. Herman Salem Caggiano, Monica, orient. Jiménez Tello, Pilar, orient. II. Título. 
Banca examinadora 


\section{AGRADECIMENTOS}

Há um conjunto de pessoas, amigas e amigos, companheiras e companheiros de jornada acadêmica e de vida que tiveram algum nível importância ao longo da elaboração desta tese e a quem tenho imensa gratidão. Infelizmente, é impossível arrolar todos aqui. De qualquer forma, expresso os meus sinceros agradecimentos:

De forma especial, à professora Monica Herman Salem Caggiano, à qual tenho o maior débito quanto à produção desta tese de doutorado. Falo não só pela oportunidade dada pela professora em estar sob a sua orientação acadêmica mas também por o todo diálogo jurídico-político que mantivemos ao longo dos últimos anos e que foram essenciais em nosso trabalho de pesquisa. Além disso, quero ressaltar o respeito, a admiração e a amizade que cultivo pela professora Monica Herman. Uma pessoa excepcional.

À professora Pilar Jiménez Tello, da Universidade de Salamanca, destacando que é uma grata surpresa da vida conhecê-la e ter tido a oportunidade de estar também sob a sua orientação acadêmica. Os períodos de estudo na Universidade de Salamanca foram primordiais para o aprimoramento do trabalho que segue. A professora Pilar Jiménez Tello nos possibilitou uma experiência intelectual e cultural inestimável.

Ao professor Cláudio Lembo, por compartilhar os seus conhecimentos e experiências. O convívio com o professor Lembo foi de extrema importância para o desenvolvimento crítico da pesquisa. A sua perspectiva humana, o seu senso de razoabilidade e o seu espírito questionador marcam todo o processo de análise desta tese.

Ao professor José Eduardo Cardozo, da Pontifícia Universidade Católica de São Paulo, por todo o incentivo acadêmico e político que me ofereceu ao longo dos anos, bem como pela amizade e confiança.

Ao professor André Singer, pelos debates proporcionados por suas aulas e pela seriedade no trato acadêmico.

Às minhas queridas alunas e aos meus queridos alunos da Faculdade Escola de Direito EPD.

Às minhas queridas alunas e aos meus queridos alunos da Faculdade de Direito da Universidade Presbiteriana Mackenzie, instituição em que iniciei a minha formação jurídica. 
Às companheiras professoras e aos companheiros professores que sempre mantiveram algum nível de debate acadêmico e político sobre os temas abordados neste trabalho, particularmente Rubens Beçak, Elisaide Trevisam, Márcia Pelegrini, Alessandro Octaviani, Rafael Tauil, Sabrina Durigon, João Victor Rozatti Longhi, Ana Paula Fuliaro, Ana Pedreira, Thiago Nogueira e Rodrigo Salgado.

Ao professor e amigo Ronaldo Pagotto, pelos debates e informações que acabaram por servir de base para algumas análises realizadas neste trabalho.

Ao amigo Thiago Henrique, pelos debates políticos travados enquanto cursávamos os créditos da pós-graduação.

À Eliane Arakaki, que fez a primeira leitura deste trabalho, sempre questionando e tecendo análises pertinentes.

À minha querida família.

Especialmente, à Caroline Rodrigues, minha companheira nessa jornada de vida, a qual teve que suportar meu distanciamento e minhas ausências ao longo da pesquisa. Sem seu amor e parceria esse trabalho não teria sentido. 
"Não condenava nada apressadamente ou sem levar em conta as circunstâncias."

Victor Hugo, em Os miseráveis, ao se referir à personagem do Bispo de Digne, Sr. CharlesFrançois-Bienvenu, mais conhecido entre o povo como Dom Bienvenu. 
SOARES, Alessandro de Oliveira. Os mecanismos de democracia direta no constitucionalismo ibero-americano: análise comparada. 2017. 706 f. Tese (Doutorado em Direito do Estado) - Faculdade de Direito da Universidade de São Paulo, São Paulo, 2017.

\section{RESUMO}

Partindo de uma abordagem de direito comparado, este estudo procura analisar os mecanismos de democracia direta estabelecidos no âmbito do atual constitucionalismo latino-americano e europeu, particularmente aqueles previstos na Constituição espanhola de 1978, brasileira de 1988, venezuelana de 1999 e equatoriana de 2008. Assim, são exploradas diversas modalidades institucionais de participação direta da cidadania no campo das decisões político-estatais, como o referendo, o plebiscito, as iniciativas populares e a revogação de mandato eletivo. Busca-se, no primeiro plano de desenvolvimento do trabalho científico, encontrar semelhanças ou diferenças, afinidades ou repulsas entre os institutos de direito político submetidos à análise. A tese defendida é a de que a Constituição brasileira de 1988, quando comparada às suas congêneres venezuelana de 1999 e equatoriana de 2008, traz em seu conteúdo um desenho normativo conservador em termos de instrumentos de democracia direta, o que significa dizer que estes: (i) não são uma via capaz de gerar bloqueios políticos (controle democrático) para medidas de caráter antipopular; (ii) não constituem potenciais saídas para amenizar crises políticas e evitar violações ao regime democrático-institucional; (iii) têm grande potencial de serem utilizados de modo a implementar políticas populistas que podem pôr em risco direitos e garantias fundamentais; e (iv) têm pouca capacidade de gerar incentivo à construção de uma democracia de alta intensidade (participativa). Ademais, verificaremos que a Constituição brasileira de 1988 se aproxima da realidade constitucional espanhola de 1978 em termos formais e de experiência, embora haja algumas distinções importantes. Por fim, são elaborados alguns indicativos a serem levados em conta em uma futura revisão do ordenamento constitucional brasileiro.

Palavras-chave: Democracia; Democracia Direta; Consulta Popular; Referendo; Plebiscito; Iniciativa Popular; Participação Popular; Revogação de Mandato; Constitucionalismo Latino-Americano. 
SOARES, Alessandro de Oliveira. The mechanisms of direct democracy in IberoAmerican constitutionalism: comparative analysis. 2017. 706 f. PhD Thesis, Faculty of Law, University of São Paulo, São Paulo, 2017.

\begin{abstract}
Based on a comparative law approach, this study aims to analyze the mechanisms of direct democracy established within the current Latin American and European constitutionalism, especially those provided for in the 1978 Spanish Constitution, the 1988 Brazilian Constitution, the 1999 Venezuelan Constitution and the 2008 Ecuadorian Constitution. Thus, several institutional arrangements of direct participation of citizenship in the fields of political-state decisions, such as the referendum, the plebiscite, the popular initiatives and the recall. This research project seeks to, in the first stage of the development of the scientific research, find similarities or differences, affinities or repulsions between the analyzed institutes of Political Law. This research proposes that the 1988 Brazilian Constitution, once compared to its counterparts, the 1999 Venezuelan Constitution and the 2009 Ecuadorian Constitution, brings a conservative normative drawing in its content in terms of instruments of direct democracy, that is to say that these: (i) are not a path able to create political barriers (democratic control) against the anti-grass roots policies; (ii) they do not constitute potential alternatives to undermine political crisis and to avoid violation of the institutional democratic regime; (iii) they could be used to implement populist policies that may put at risk the fundamental rights and securities; and (iv) they have little capacity to provide incentive to the building of a high intensity democracy (participative). Furthermore, it has been shown that the 1988 Brazilian Constitution is close to the Spanish constitutional reality of 1978 both in formal matters as in terms of experience, although there remain some important distinctions. Finally, we have developed several indicatives to be taken into account in a future revision of the Brazilian constitutional order.
\end{abstract}

Key-words: Democracy; Direct Democracy; Popular Consultation; Referendum; Plebiscite; Popular Initiative; Recall; Latin-American Constitutionalism. 
SOARES, Alessandro de Oliveira. Los mecanismos de democracia directa en el constitucionalismo latinoamericano: análisis comparativo. 2017. 706 f. Tesis (Doctorado en Derecho Público) - Facultad de Derecho de la Universidad de Sao Paulo, Sao Paulo, 2017.

\section{RESUMEN}

Partiendo de un abordaje de derecho comparado, este estudio busca analizar los mecanismos de democracia establecidos en el ámbito de actual constitucionalismo latinoamericano y europeo, particularmente aquellos previstos en la constitución española de 1978, brasileña de 1988, venezolana de 1999 y ecuatoriana de 2008. Así, son exploradas diversas modalidades institucionales de participación directa de ciudadanía en el campo de las decisiones político-estatales, como el referendo, plebiscito, iniciativas populares y la revocación de mandato electivo. Se busca, en el primer plano de desarrollo del trabajo científico, encontrar similitudes o diferencias, afinidades o repulsas entre los institutos de derecho político sometidos a análisis. La tesis defendida es que la constitución brasileña de 1988, cuando comparada a sus congéneres venezolanas de 1999 y ecuatoriana de 2008, trae en su contenido un dibujo normativo conservador en términos de instrumentos de democracia directa, lo que significa decir que esos: (i) no son una vía capaz de generar bloqueos políticos (control democrático) para medidas de carácter antipopular; (ii) no constituyen potenciales salidas para amenizar crisis políticas y evitar violaciones al régimen democrático institucional; (iii) tiene gran potencial que sean utilizados de modo a implementar políticas populistas que pueden poner en riesgo derechos y garantías fundamentales; y (iv) tienen poca capacidad de generar incentivo a la construcción de una democracia de alta intensidad (participativa). Sin embargo, verificaremos que la constitución brasileña de 1988 si acerca de realidad constitucional española de 1978 en términos formales y de experiencia, aunque haya algunas distinciones importantes. Finalmente, son elaborados algunos indicativos que son llevados en cuenta en una futura revisión de ordenamiento constitucional brasileño.

Palabras-clave: Democracia; Democracia Directa; Consulta Popular; Referendo; Plebiscito; Iniciativa Popular; Participación Popular; Revocación de Mandato; Constitucionalismo Latinoamericano. 


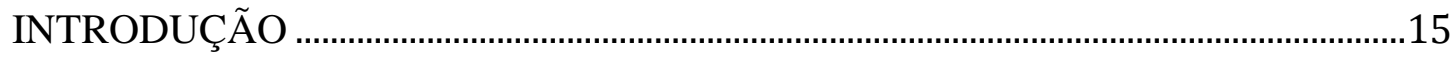

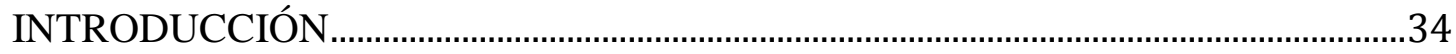

CAPÍTULO 1 - DEMOCRACIA, REPRESENTAÇÃO POLÍTICA E GÊNESE DOS MECANISMOS DE DEMOCRACIA DIRETA.................................................................54

1.1 A participação política direta como base do sistema político: o protótipo grego ...55

1.1.1 A estrutura decisória e as suas características essenciais ...........................................56

1.2 A participação política na democracia representativa ...........................................................67

1.2.1 A representação política moderna: a revolução como demanda por participação política ...................................................................................................................................68

1.2.2 Resultante institucional dos princípios de participação via representação e efeitos secundários ......................................................................................................................73

1.2.3 A representação e a engenharia de institutos limitativos à participação ..................76

1.3 Conclusão quanto ao modelo de participação na democracia representativa ...................79

1.4 Da crítica à representação política aos mecanismos de democracia direta.........................80

CAPÍTULO 2 - MECANISMOS DE DEMOCRACIA DIRETA E O SISTEMA DE DEMOCRACIA REPRESENTATIVA: COMPREENSÃO TEÓRICA, CONCEITOS

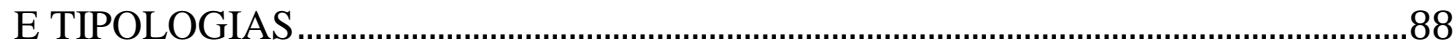

2.1 A ideia de sistema de democracia semidireta.................................................................88

2.2 Mecanismos de democracia direta, democracia participativa, democracia deliberativa e

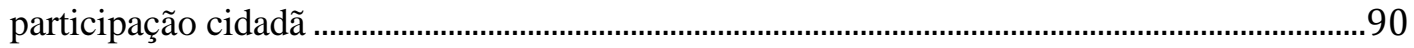

2.3 Os mecanismos de democracia direta: tipologia e delineamentos.......................................98

2.3.1 Consultas populares .............................................................................................. 100

2.3.1.1 Referendo e plebiscito: aspectos terminológicos conceituais ..........................................100

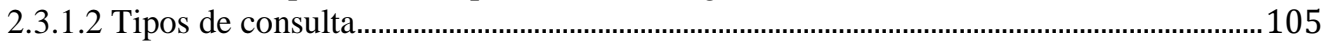

2.3.1.2.1 Objeto das consultas ....................................................................................................105

2.3.1.2.2 Consulta obrigatória e consulta facultativa ................................................................107

2.3.1.2.3 Consulta vinculante e meramente consultiva..............................................................110

2.3.1.2.4 Consulta popular como poder de veto e derrogação ………………………………..112

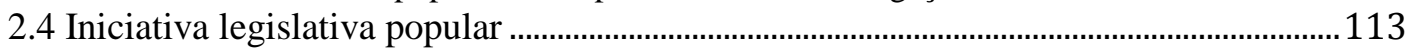

2.5 Iniciativa popular como competência e suas diversas finalidades....................................119

2.6 Revogação de mandato....................................................................................................... 120

CAPÍTULO 3 - CONTROVÉRSIAS E CRÍTICA AOS MECANISMOS DE

DEMOCRACIA DIRETA ……………………………………....................................125

3.1 Mecanismos de democracia direta e tensões com o sistema representativo....................125

3.2 Da crítica à capacidade de decidir à irracionalidade institucional da democracia direta

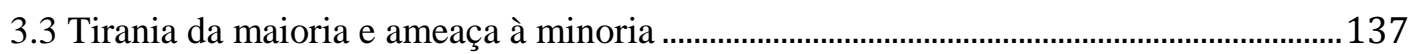

3.3.1 Ponderações quanto à visão de que os mecanismos de democracia direta levam à

tirania da maioria ........................................................................................................... 144

3.3.2 A democracia direta e as suas funções majoritárias e contramajoritárias: quem

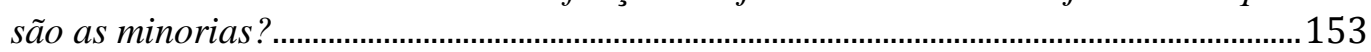

3.4 Qualidade das regras normativas produzidas e a democracia direta................................161

3.5 Utilização dos mecanismos em tempos de crise e assuntos de comoção: reforçando a

irracionalidade?

3.6 Mecanismos de democracia direta e irracionalidade no plano das políticas públicas.163

3.7 O poder do dinheiro e a "industrialização" da democracia direta 164

3.8 Os mecanismos de democracia direta e a formulação da proposta oferecida à cidadania

3.9 O uso autoritário dos mecanismos de democracia direta... 
3.10 A revogação de mandato: controvérsias.

180

3.11 Iniciativa popular e desestabilização do governo: os riscos de banalização do instituto

CAPÍTULO 4 - OS MECANISMOS DE DEMOCRACIA DIRETA NO

CONSTITUCIONALISMO EQUATORIANO.............................................................185

4.1 Os mecanismos de democracia direta na Constituição de 1979........................................185

4.1.1 Previsão constitucional de mecanismo de democracia direta ...................................191

4.1.2 Consulta popular de $1^{\circ}$ de junho de 1986................................................................193

4.1.3 Consulta popular de 28 de agosto de 1994.............................................................196

4.1.4 Consulta popular de 26 de novembro de 1995 ...........................................................198

4.1.5 Consulta popular de 25 de maio de 1997...............................................................199

4.2 A democracia direta na Constituição de 1998 ………………………………………….......204

4.2.1 Previsão normativa de mecanismo de democracia direta .........................................2208

4.2.2 A "revogação de mandato" de Jamil Mahuad .........................................................212

4.2.3 A "revogação de mandato" de Lucio Gutiérrez ……………………….....................213

4.2.4 Consulta popular de 26 de novembro de 2006 .......................................................220

4.2.5 A eleição de Rafael Correa e a consulta popular de 15 de abril de 2007 ..............221

4.2.6 Consulta popular de 28 de setembro de 2008 (aprovação da nova Constituição)

4.2.7 O uso dos mecanismos de democracia direta no Equador entre 1978 e 2008 -

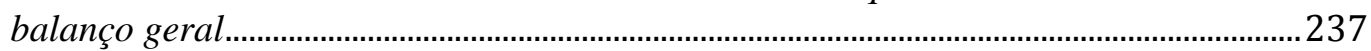

4.3 Os mecanismos de democracia direta na Constituição de 2008........................................243

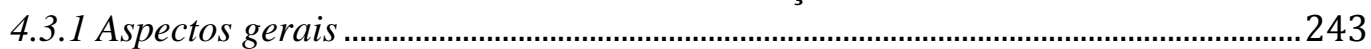

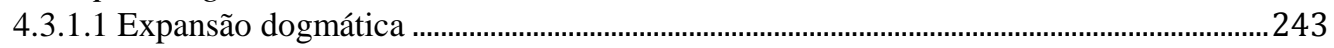

4.3.1.2 O espírito "participacionista" de Montecristi .....................................................................246

4.3.1.3 Crítica à parte orgânica: hiperpresidencialismo ...............................................................248

4.3.2 Direito de participação política e mecanismos de democracia direta....................249

4.3.2.1 Iniciativa popular normativa …………………………..................................................224

4.3.2.2 Iniciativa popular normativa: efeitos da rejeição e modificação do projeto..................260

4.3.2.3 Iniciativa popular normativa para reforma parcial da Constituição ................................262

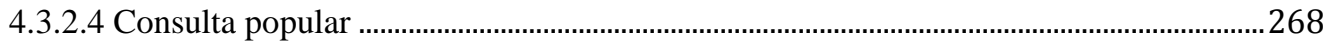

4.3.2.4.1 Prazos e número de votos para a aprovação das consultas populares ....................272

4.3.2.5 Revogação de mandato ..................................................................................................22

4.3.2.6 Consulta popular para a autorização de atividade extrativista.........................................285

4.3.2.7 Consulta popular para conformação de região autônoma ................................................287

4.3.2.8 Referendo para ratificação de tratados internacionais .....................................................228

4.3.2.9 Referendo para emenda da Constituição .....................................................................2290

4.3.2.9.1 Iniciativa ..................................................................................................................292

4.3.2.9.2 Limites materiais da proposta ……………………................................................293

4.3.2.10 Consulta popular para a realização de Assembleia Constituinte.....................................294

4.3.2.11 Consulta obrigatória para reforma parcial da Constituição..............................................296

4.3.3 A Corte Constitucional e os procedimentos de democracia direta .........................296

4.3.3.1 A iniciativa para a reforma constitucional e a definição do procedimento de "emenda"

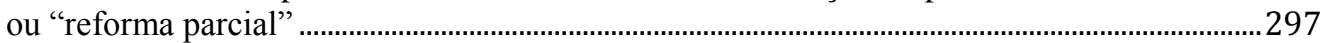

4.3.3.2 Controle de constitucionalidade prévio das consultas para emenda ou reforma

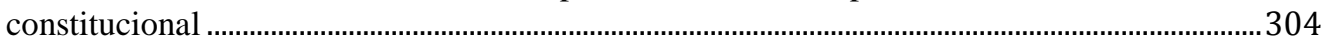

4.4 Experiências com os mecanismos de democracia direta pós-Constituição de 2008 ....308

4.4.1 Consulta popular e referendo de 07 de maio de 2011 ................................................308

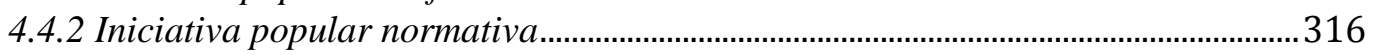

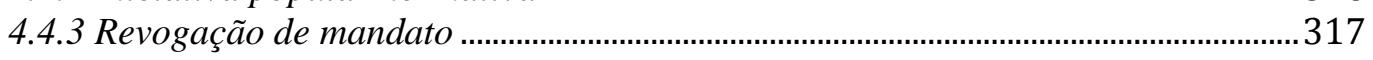

4.5 As eleições de 2013 e o cenário político para a aplicação dos mecanismos de

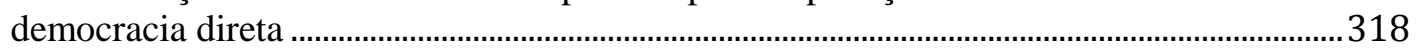

4.5.1 Proposta de emenda à Constituição em 26 de junho de 2014 ...................................319 


\section{CAPÍTULO V - A DEMOCRACIA DIRETA NO CONSTITUCIONALISMO}

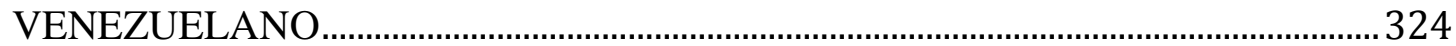

5.1 A Constituição de 1999 como resultado de uma crise política...........................................324

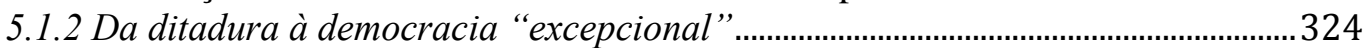

5.1.2.1 O Pacto de Punto Fijo ..............................................................................................................324

5.1.2.2 Base econômica de sustentação do Pacto de Puntu Fijo: petróleo ......................................335

5.1.3 Crise, demanda democracia participativa e a Constituinte de 1999.......................340

5.1.3.1 Raiz da crise de Punto Fijo .................................................................................................340

5.1.3.2 Reforma Constitucional frustrada - democracia direta na Lei Orgânica do Sufrágio e

Participação Política de 1997.............................................................................................................354

5.1.3.3 Eleição de 1998 - Hugo Chávez no poder e a promessa de participação política........357

5.1.3.4 Referendo sobre a convocação da Constituinte de 1999 ...................................................361

5.1.3.5 Referendo para aprovação da Constituição de 1999.........................................................370

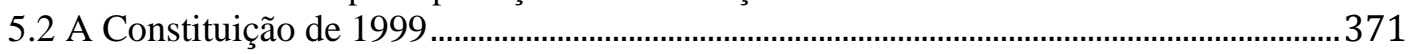

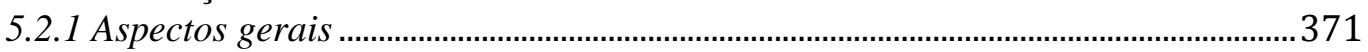

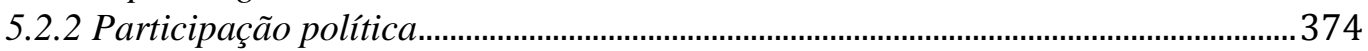

5.2.3 Mecanismos de democracia direta na Constituição de 1999...................................377

5.2.3.1 Referendo para criação de territórios ...................................................................................377

5.2.3.2 Referendo consultivo em matérias de especial transcendência ..........................................378

5.2.3.3 Referendo para revogação de mandato...………………………………………………......380

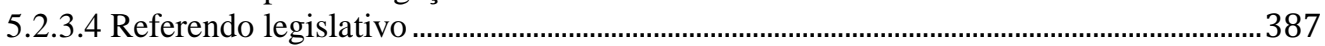

5.2.3.5 Referendo para aprovação de tratados internacionais ......................................................388

5.2.3.6 Referendo revogatório de lei e decreto-lei presidencial .....................................................38

5.2.3.7 Consulta popular para a escolha dos membros do Poder Cidadão......................................390

5.2.3.8 Referendo para aprovação de emenda constitucional........................................................391

5.2.3.9 Referendo para aprovação de reforma constitucional .......................................................394

5.2.3.10 Iniciativa popular para convocação de Assembleia Nacional Constituinte.................396

5.2.3.11 Iniciativa legislativa popular..........................................................................................397

5.2.4 Regulação infraconstitucional dos mecanismos de democracia direta ...................399

5.3 Experiências de democracia direta .......................................................................................... 401

5.3.1 Megaeleições de julho de 2000..............................................................................4

5.3.2 Referendo Sindical de 03 de dezembro de 2000...................................................... 405

5.3.3 Golpe de Estado contra Chávez em 2002 - "revogação de mandato" por outros

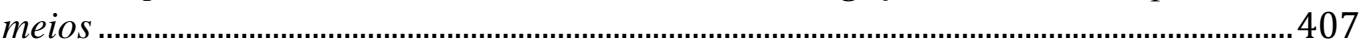

5.3.4 Tentativa de referendos consultivos contra Chávez................................................. 412

5.3.5 Referendo revogatório presidencial de 2004 ......................................................... 415

5.3.6 Referendo sobre a reforma constitucional de 02 de dezembro de 2007.................435

5.3.7 Referendo sobre a emenda à Constituição de 15 de fevereiro de 2009.................. 447

5.4 Alguns apontamentos quanto à aplicação dos mecanismos de democracia direta na vigência da Constituição de 1999......................................................................................... 452

5.5 Desafios estruturais do Estado venezuelano e o período bolivariano: obstáculos democráticos

CAPÍTULO 6 - DEMOCRACIA DIRETA NO CONSTITUCIONALISMO

6.1 Trajetória histórica dos mecanismos de democracia direta pré-Constituição de 1978458

6.1.1 O século XIX e o constitucionalismo tradicional......................................................458

6.1.2 A democracia direta na Constituição de 1931 .......................................................... 460

6.1.3 Fim da Segunda República, a guerra civil espanhola e a ditadura franquista.... 462

6.1.4 Regime de Franco e a participação direta................................................................. 464

6.1.5 A transição democrática e o referendo de 15 de dezembro de 1976.......................470

6.1.6 Processo constituinte e democracia direta ……………………………………….... 478

6.2 Fundamentos democráticos no sistema político da Constituição de 1978: espírito

participativo e social........................................................................................................... 482

6.2.1 Os mecanismos de democracia direta na Constituição de 1978..............................485

6.2.1.1 Iniciativa legislativa popular ..........................................................................................485 
6.2.1.2 Referendo sobre decisões políticas de especial transcendência .......................................496

6.2.1.3 Referendo regional ou autonômico ..................................................................................511

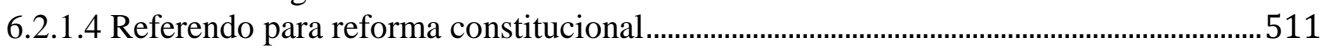

6.2.1.4.1 Referendo facultativo para reforma constitucional ordinária .................................513

6.2.1.4.2 Referendo obrigatório para reforma constitucional extraordinária .........................516

6.2.2 A democracia participativa como aspecto "enganoso" na Constituição de 1978

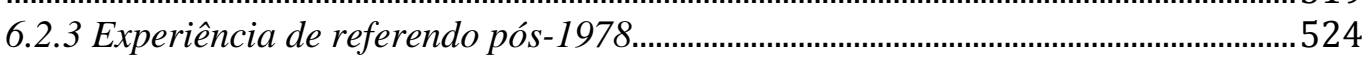

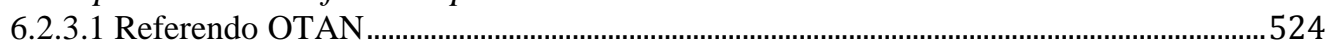

6.2.3.2 Referendo sobre a Constituição da Europa ........................................................................527

6.2.3.3 Reformas constitucionais sem manifestação da cidadania .............................................528

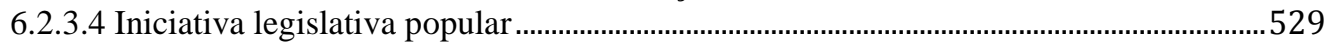

CAPÍTULO 7 - OS MECANISMOS DE DEMOCRACIA DIRETA NO CONSTITUCIONALISMO BRASILEIRO ……………………………………………....531

7.1 Trajetória pré-Constituição de 1988........................................................................531

7.1.1 Estado-nação e cidadania retida ....................................................................................... 531

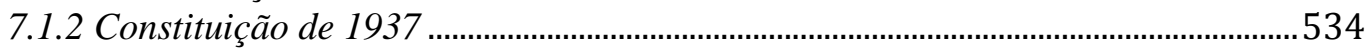

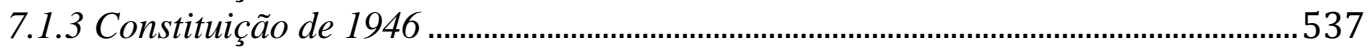

7.1.4 Constituição de 1967 .............................................................................................................54 54

7.1.5 Participação contida, eleições plebiscitárias e transição democrática ..................545

7.1.6 O processo constituinte de 1987-1988 e a participação popular ...............................549

7.2 A Constituição de 1988 e os mecanismos de democracia direta........................................554

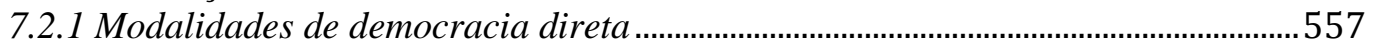

7.2.1.1 Consulta popular: referendo e plebiscito ..............................................................................557

7.2.1.2 Plebiscito sobre organização territorial político-administrativa ........................................562

7.2.1.3 Iniciativa legislativa popular ..........................................................................................564

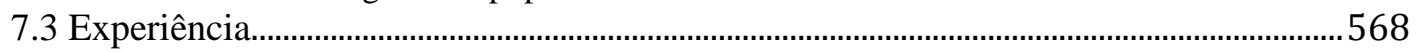

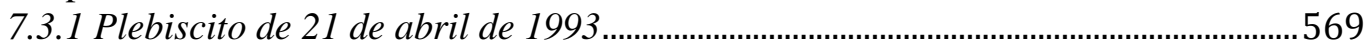

7.3.2 Referendo de 23 de outubro de 2005 ..........................................................................570

7.3.3 Plebiscito $(s)$ de 11 de dezembro de 2011 .....................................................................574

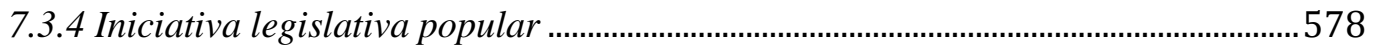

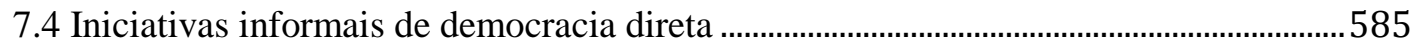

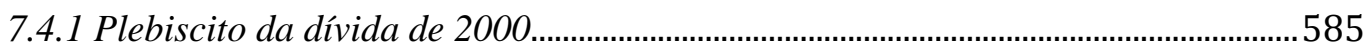

7.4.2 Plebiscito da ALCA de 2002 .............................................................................................587

7.4.3 Plebiscito de anulação da privatização da empresa Vale do Rio Doce de 2007.588

7.4.4 Rebeliões de junho de 2013 e o plebiscito de uma Constituinte para reforma do sistema político ............................................................................................................................... 589

CAPÍTULO 8 - PERSPECTIVA COMPARADA E PROPOSTAS LEGE FERENDA

598

8.1 Iniciativa popular para convocação de referendo e plebiscito ...........................................598

8.2 Procedimento de reforma constitucional e democracia direta ............................................608

8.3 Iniciativa de consulta popular para convocação de Assembleia Nacional Constituinte

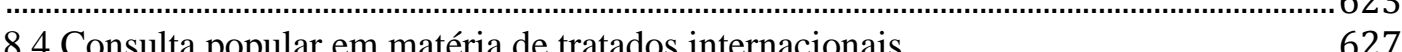

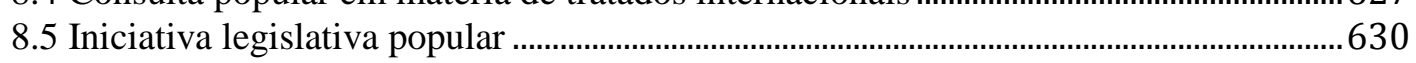

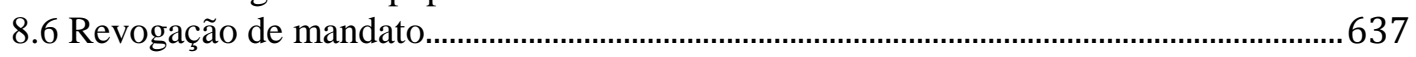

CONCLUSÃO

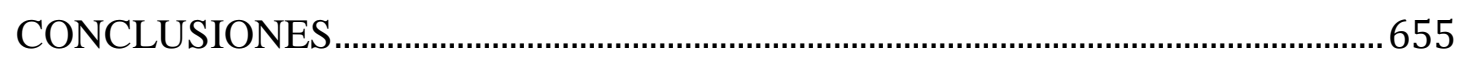

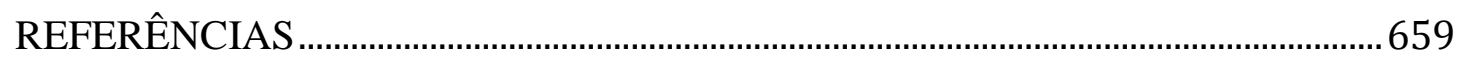




\section{INTRODUÇÃO}

De um ponto de vista ideal, a democracia baseia-se no princípio de que um povo tem o direito de se autogovernar, ditar o seu próprio destino. Igualdade, liberdade e soberania estão aqui em plena sintonia. Mas a democracia, enquanto expressão de uma estrutura de dominação política, deve se constituir como uma institucionalidade capaz de dar vida a relações sociais de poder particularizadas. Em outras palavras, faz-se sempre necessário definir os caminhos a serem seguidos ao longo dos processos decisórios sobre questões que digam respeito ao destino de toda comunidade. De um princípio genérico e abstrato, o qual prega que a titularidade do poder pertence a todos os integrantes de um agrupamento político, é preciso chegar à condição de ação efetiva, uma vez que existe um espaço a ser percorrido entre a titularidade do poder (potência) e o seu exercício. ${ }^{1}$

Se por um lado a democracia moderna é marcada pela existência de processos eleitorais para a escolha de representantes que assumem a responsabilidade pelas decisões políticas no cotidiano, conduzindo a maquinaria estatal, por outro há a presença perturbadora dos mecanismos de democracia direta possibilitando que, em situações pontuais e excepcionais, a cidadania adote uma posição sobre determinada questão política que tenha ganhado relevância. Impende verificar que a elaboração e a introdução de mecanismos de democracia direta, por exemplo, referendos e plebiscitos, ocorrem como uma resposta aos problemas (ou crises) vivenciados pela representação política. ${ }^{2}$

A ineficiência, ineficácia e inefetividade da atividade política em criar situações sociais e econômicas estáveis e seguras para grande parte das populações nos Estados contemporâneos faz com que se tenha cada vez mais desconfiança dos representantes políticos e do próprio sistema representativo. O raciocínio quanto a esse aspecto é simples: os agentes políticos são incapazes de sempre buscar ou

\footnotetext{
${ }^{1}$ SARTORI, Giovanni. Homo videns: televisão e pós-pensamento. Tradução de Antonio Angonese. São Paulo: Edusc, 2001, p. 108.

${ }_{2}^{2}$ EULE, Julian N. Judicial review of direct democracy. The Yale Law Journal, v. 99, n. 7, p. 1517

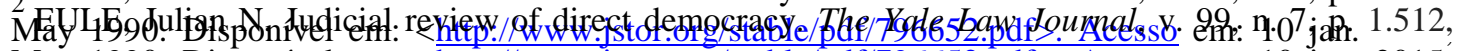
May 1990. Disponível em: 〈http://www.jstor.org/stable/pdf/796652.pdf>. Acesso em: 10 jan. 2015; LISSIDINI, Alicia. Democracia directa en latinoamérica: entre la delegación y la participación. Buenos Aires: Consejo Latinoamericano de Ciencias Sociales - CLACSO, 2011, p. 42; COOTER, Robert D.; GILBERT, Michael D. A theory of direct democracy and the single subject rule. Columbia Law Review, v. 110, n. 3, p. 694, Apr. 2010; AGESTA, Luis Sánchez. Curso de derecho constitucional comparado. Madrid: Universidad de Madrid, 1980, p. 184.
} 
expressar de maneira confiável o interesse público e o bem comum; pelo contrário, estão sempre aptos a se guiarem por seus próprios interesses particulares ou de elites econômicas muitas vezes estranhas à cidadania. Com efeito, conferir a cidadãs e cidadãos a competência para tomarem diretamente decisões políticas aparece como uma tentativa de neutralizar os defeitos demonstrados pela representação política, tudo indica assim que a insatisfação estaria na origem da demanda por participação $\operatorname{direta}^{3}$.

Como uma espécie de corretivo ou remédio amargo aos problemas evidenciados pela representação política, os mecanismos de democracia direta estão presentes hoje em grande parte dos ordenamentos constitucionais democráticos. Diante disso, Svensson afirma que poucos países não preveem algum tipo de instituto de participação direta da cidadania, se não em nível nacional, ao menos em nível local. ${ }^{4}$ Constata-se, então, que a existência dos institutos de participação direta são uma realidade jurídica incontestável, embora se possa levantar objeções sobre a compatibilidade ou mesmo a pertinência desses institutos em ambiente representativo.

Uma vez disponíveis para uso nos diversos países que os adotam, há uma tendência geral de se pôr os institutos de democracia direta em prática. Tal circunstância se vê aprofundada quando imaginamos que as crises vivenciadas no âmbito dos sistemas representativos tendem a ser permanentes, ${ }^{5}$ correspondendo, assim, a um estágio ordinário das democracias contemporâneas, e não a uma circunstância excepcional a conturbar o ambiente político. Esse retrato amplo parece estar presente nas análises de Maduz: "o aumento recentemente observado no uso de instrumentos democráticos diretos em diferentes regiões do mundo (referendos e

\footnotetext{
3 CANOTILHO, José Joaquim Gomes. "Brancosos" e interconstitucionalidade: itinerários dos discursos sobre a historicidade constitucional. $2^{\mathrm{a}}$ ed. Coimbra: Almedina, 2012, p. 313.

${ }^{4}$ SVENSSON, Palle. Forms and terminology of direct democracy. Paper presented at the Conference of IPSA and ECPR, São Paulo, 2011, p. 03. Disponível em <http://paperroom.ipsa.org/ papers/paper 26306.pdf>. Acesso em: $1^{\circ} \mathrm{fev} .2015$.

${ }^{5}$ Pode parecer algo contraditório, mas essa situação se vincula à própria expansão dos sistemas de democracia representativa no mundo. Sobre esse aspecto, vejamos as análises de Altman: "The importance of direct democracy in current debate in the discipline is enhanced by the fact that 'normal' electoral politics are problematic. Today, this debate is even more intense because we face two contradictory scenarios. On the one hand, never more than before have so many people around the globe been free to elect their leaders in a democratic manner. On the other hand, more often than not, democratic performance seems to be challenged by the emergence of public disaffection, weak rule of law, the corruption (both real and assumed) of elected officials, an increasing gap between the rich and the poor, a lack of accountability and transparency, and the continuous marginalization of important groups in society, among other factors". ALTMAN, David. Direct democracy worldwide. New York: Cambridge University Press, 2011, p. 33.
} 
projetos de iniciativa popular), bem como a incorporação de dispositivos relacionados a um número de novas constituições, explica o crescente interesse no tema". 6

Deve-se notar que, dependendo de cada ordenamento jurídico nacional, observaremos uma diversidade de desenhos normativos dos mecanismos de democracia direta - mais do que isso, como é óbvio, cada realidade em que será implementada a participação direta dos cidadãos sofre também variação. Assim, a discussão que parece estar posta no horizonte é exatamente quanto ao uso e efeitos dos institutos de participação direta em contexto democrático. De fato, estes podem desempenhar muitos papéis no campo político dependendo das formas como são previstos normativamente e em face da conjuntura em que são aplicados. ${ }^{7}$ Com efeito, um dos debates mais importantes da atual agenda jurídico-política é a necessidade de discutir os potenciais benefícios e riscos dessas instituições, ${ }^{8}$ principalmente reconhecendo vivências de crises econômicas e sociais pela qual passamos nos últimos tempos. Em princípio, podemos universalizar a afirmação de Cronin de que os mecanismos de democracia direta chegaram para ficar; no entanto, melhorias ainda são necessárias para remediar possíveis abusos e efeitos negativos em sua aplicação. ${ }^{9}$

Dessarte, considerando as reais potencialidades dos mecanismos de democracia direta, é preciso pensar criticamente nos melhores desenhos normativos

\footnotetext{
${ }^{6}$ Tradução nossa do original: "the recently observed increase in the use of direct democratic instruments in different regions of the word (referendums and initiatives), as well as the incorporation of related provisions in a number of new constitutions, explains the growing interest in the subject matter". MADUZ, Linda. Direct democracy. Living Reviews in Democracy, ETH Zurich and University of Zurich, v. 2, p. 02, 2010.

${ }^{7}$ Nesse sentido diz Canotilho particularmente sobre os referendos: "O referendo, ou melhor, os vários tipos de refendo podem desempenhar várias funções no sistema político, consoante a sua regulação normativa, o tipo de estdo (unitário, federal), os sistemas eleitorais, os sistemas de partidos e a cultura política." CANOTILHO, José Joaquim Gomes. "Brancosos" e interconstitucionalidade: itinerários dos discursos sobre a historicidade constitucional..., cit., p. 303. Nos últimos anos, a potencialidade dos mecanismos de democracia direta foi posta à prova na Europa, servindo de instrumento de reação popular contra medidas pró-mercado e de austeridade. Pisarello lembra algumas dessas experiências: "Así, por ejemplo, los referendos conquistados y ganados por la ciudadanía islandesa en contra de los intereses de las entidades financeiras y de la clase política responsable por la generación de la crisis. Del referéndum esloveno promovido por diferentes organizaciones sindicales para rechazar la regresiva reforma de las pensiones impulsada por el Gobierno. O de los referendos italianos que consiguieron detener la privatización del agua, el regreso de la energía nuclear o el mantenimiento de privilegios procesales para ciertos cargos del Estado, y cuyo valor constituyente no puede subestimarse". PISARELLO, Gerardo. Un largo termidor. La ofensiva del constitucionalismo antidemocrático. Madrid: Editorial Trotta, 2011, p. 210.

${ }^{8}$ GARETTO, Daniel Zovatto. Las instituciones de la democracia directa a nivel nacional en América Latina: un balance comparado: 1978-2007. Revista de Derecho Electoral, n. 4, Tribunal Supremo de Elecciones, San José, p. 04, 2. sem. 2007.

${ }^{9}$ CRONIN, E. Thomas. Direct democracy. The politics of initiative, referendum, and recall. Harvard University Press, 1999, p. 232. Falamos em universalização da afirmação de Cronin na medida em que esse autor trata especificamente da situação dos mecanismos de democracia direta nos Estados Unidos.
} 
no que diz respeito à legitimidade democrática das decisões políticas do Estado. Nas palavras de Garetto, "se os mecanismos de democracia direta são devidamente utilizados, podem ajudar a contrariar a tendência à deslegitimação do sistema político". ${ }^{10}$ Com perspectiva similar Canotilho afirma que o referendo, uma vez "constitucionalmente regulado, pode e deve considerar-se como um esquema instrumental de dinamização da democracia política"11, sendo que "a sua positivação constitucional pode emprestar-lhe previsibilidade calculabilidade, transparência, segurança"12.

Com efeito, esta pesquisa adota o ponto de vista da necessidade de adaptação da democracia representativa às demandas políticas da sociedade, esta última cada vez mais diversa e complexa, sendo os mecanismos de democracia direta instrumentos importantes para a realização desse ajuste. 13 A construção de um constitucionalismo democrático passa pela combinação de formas de participação direta e representativa.14 Ressalte-se desde já que não alimentamos qualquer tipo de ilusão quanto à intervenção direta da cidadania na esfera política, da mesma maneira que não temos maiores expectativas quanto à representação política. Nesse sentido, concordamos com Ferrajoli, o qual pontua que a ideia de uma "vontade popular boa é uma ilusão",15 acrescendo ainda que tampouco esta é naturalmente má.

Dito isso, no trabalho que segue, vamos nos debruçar sobre os mecanismos de democracia direta estabelecidos no âmbito do atual constitucionalismo latinoamericano e europeu, particularmente aqueles previstos na Constituição espanhola de 1978, brasileira de 1988, venezuelana de 1999 e equatoriana de 2008. Trata-se, com efeito, de um estudo jurídico-constitucional de natureza comparativa, ${ }^{16}$ isto é,

\footnotetext{
${ }^{10}$ Tradução nossa do original: "si los mecanismos de democracia directa son debidamente utilizados pueden ayudar a contrarrestar la tendencia a la delegitimación del sistema político". GARETTO, Daniel Zovatto. Las instituciones de la democracia directa a nivel nacional en América Latina..., cit., p. 49.

11 CANOTILHO, José Joaquim Gomes. "Brancosos" e interconstitucionalidade: itinerários dos discursos sobre a historicidade constitucional..., cit., p. 306.

12 CANOTILHO, José Joaquim Gomes. "Brancosos" e interconstitucionalidade: itinerários dos discursos sobre a historicidade constitucional..., cit., p. 306.

${ }^{13}$ LISSIDINI, Alicia. Democracia directa en latinoamérica..., cit., p. 20.

${ }^{14}$ PISARELLO, Gerardo. Un largo termidor, cit., p. 211.

15 FERRAJOLI, Luigi. Poderes salvajes. La crisis de la democracia constitucional. Tradução de Andrés Ibánez. Madrid: Editorial Trotta, 2011, p. 65.

${ }^{16} \mathrm{Na}$ definição temática da proposta desta tese, utilizamos a terminologia "direito comparado". É pertinente notar, entretanto, que é criticável o termo escolhido, uma vez que o direito comparado não configura um campo normativo específico com conteúdo próprio, como o direito civil ou constitucional, mas denota, principalmente, a análise de campos do direito, o que leva alguns a
} 
procura-se, no primeiro plano de desenvolvimento do trabalho científico, encontrar semelhanças ou diferenças, afinidades ou repulsas entre os institutos de direito político submetidos à análise. $^{17}$

No horizonte investigativo, encontramos construções normativas presentes em ordenamentos constitucionais distintos, mas que guardam certo grau de parentesco. Sobre esse aspecto, convém observar que o desdobramento de toda a pesquisa no âmbito do direito comparado exige, como pressuposto lógico, o mínimo de similaridade ou analogia entre os institutos estudados, quer dizer, há necessidade de que os objetos sejam comparáveis. ${ }^{18}$ Seria inapropriada a comparação de objetos de natureza e significados distintos.

Nessa ordem de ideias, este trabalho está centrado em duas formas de expressão concreta dos mecanismos de democracia direta: (i) todas as modalidades de consultas submetidas à manifestação popular direta e imediata que digam respeito a uma reforma constitucional, de lei ou expedição de medida administrativa ou ato político, abrangendo também as consultas que tenham por objetivo a revogação de uma lei vigente, independentemente da nomenclatura que essas consultas receberam nas diversas ordens constitucionais (consulta popular, referendo ou plebiscito); (ii) todas as formas de iniciativa fundadas na petição de fração dos eleitores no exercício de competências constitucionais e que tenham por objetivo a prática de determinada

advogarem pela adoção de outras definições mais apropriadas, por exemplo, "comparação de direitos". Embora aceitando a crítica, não significa que tenhamos que abrir mão do termo elegido, pois este está firmemente estabelecido nas discussões científico-jurídicas. Sobre esse ponto, ver CRUZ, Peter de. Comparative law in a changing world. $3^{\text {rd }}$ ed. Edition. London: Routledge-Cavendish, 2007, p. 07.

17 CARPIZO, Jorge. Derecho constitucional latinoamericano y comparado. Boletín Mexicano de Derecho Comparado, Universidad Nacional Autónoma de México, v. XXXVIII, n. 114, p. 950, sept.dic. 2005; MIRANDA, Jorge. Sobre o direito constitucional comparado. Revista de Direito Constitucional e Internacional, v. 55, ano 14, p. 244, abr.-jun. 2006; ANCEL, Marc. Utilidade e métodos do direito comparado. Tradução de Sérgio José Porto. Porto Alegre: Sergio Antonio Fabris Editor, 1980, p. 44-45. Embora haja um conflito entre os comparatistas quanto a identificar a ideia de "direito comparado" como ciência ou puro método, parece não haver grandes discordâncias no que diz respeito ao aspecto da realização prática da comparação, isto é, que o direito comparado sempre envolve um procedimento metodológico. Nesse sentido, vejamos o que diz Pegoraro: "Derecho Comparado puede reinvindicar la dignidad de ciencia sólo desde que la finalidad que persigue no es otra que la de sistematizar los materiales jurídicos de un ordenamientos con la idea de ofrecer una comparación, de verificar las analogías y las diferencias, de clasificar institutos y sistemas, dando orden al conocimiento y creando modelos dotados de prescritividad”. PEGORARO, Lucio. El método en el derecho constitucional: la perspectiva desde el derecho comparado. Revista de Estudios Políticos (Nueva Época), n. 112, p. 14, abr.-jun. 2001.

${ }^{18}$ ZWEIGERT, Konrad; KÖTZ, Hein. Introduction to comparative law. $3^{\text {rd }}$ ed. rev. Tradução de Tony Weir. Oxford: Claredon Press, 1998, p. 15; PEGORARO, Lucio. El método en el derecho constitucional..., cit., p. 15; DUVERGER, Maurice. Metodos de las ciencias sociales. Tradução de Alfonso Sureda. Barcelona: Ariel, 1980, p. 412-413; SILVA, José Afonso da. Um pouco de direito constitucional comparado. Três projetos de Constituição. São Paulo: Malheiros, 2009, p. 21. 
medida, como forçar a realização de novo pleito eleitoral ou consulta para a revogação de mandato político, a implementação de uma consulta popular, a apresentação de proposta legislativa ou tema constitucional frente ao Poder Legislativo (iniciativa legislativa popular) e a convocação de eleição para uma Assembleia Constituinte.

Importante ressaltar que as análises recairão particularmente sobre os institutos de aplicação nacional, excluindo de nosso campo exploratório as normas e experiências de caráter subnacional ou local. Não significa que vamos ignorar tais regras e experiências, mas apenas que não são o foco de nossas preocupações.

Obviamente, a comparação dos institutos de democracia direta presentes em ordenamentos nacionais distintos corresponde tanto a um procedimento analítico ${ }^{19}$ quanto a uma finalidade imediata. Devemos afirmar isso de maneira redundante, mas necessária: a finalidade do estudo que se segue é realizar uma comparação que terá como resultado uma análise comparativa. No entanto, o estudo irá um pouco além. Com efeito, há que se fazer referência a um objetivo final da pesquisa, que é estabelecer apontamentos propositivos de ordem jurídica passíveis de servir de ponto de partida a uma futura alteração na regulação constitucional brasileira de $1988 .^{20}$ Dessa forma, alinhamo-nos ao ponto de vista de que a pesquisa em direito comparado tem um papel importante no campo da política legislativa. Aceitando essa perspectiva, Carpizo estatui que a análise comparada de instituições constitucionais tem "a finalidade primordial de examinar quais delas podem ajudar a fortalecer um sistema constitucional específico". ${ }^{21}$

\footnotetext{
${ }^{19}$ Como destacam Zweigert e Kötz, o direito comparado corresponde a uma "intellectual activity with law as its object and comparison as its process". ZWEIGERT, Konrad; KÖTZ, Hein. Introduction to comparative law, cit., p. 02.

${ }^{20}$ Não consideramos convenientes análises abstratas sobre quais são "as melhores" e "as piores" instituições. Nesse sentido, Jansen alerta para o fato de que "evaluation of the objects compared is not a part of the comparative process. Comparative knowledge may be used to justify normative statements, but comparison itself neither proves the truth of a belief nor reveals one legal rule or doctrine to be superior to others". JANSEN, Nils. Comparative law and comparative knowledge. In: REIMAN, Mathias; ZIMMERMANN, Reinhard (Eds.). The Oxford handbook of comparative law. New York: Oxford University Press, 2006, p. 337.

${ }^{21}$ Tradução nossa do original: "la finalidad primordial de examinar cuáles de ellas pueden auxiliar a fortalecer un sistema constitucional específico". CARPIZO, Jorge. Derecho constitucional latinoamericano y comparado, cit., p. 950. Não difere também da posição de Blagojevic: "Il est certainement possible et justifié de procéder, dans les dites études, à une analyse critique ante des modalités, de la technique et de l'intégralité des solutions dans les droits respectifs que de l'application, et des conséquences de l'application, de ces solutions dans le pays envisagé. Or, dans de nombreux cas ces études vont jusqu'à donner une appréciation, ou au moins une analyse critique, de la valeur des solutions dans un droit doné. Cette appréciation peut être d'une double nature; ou bien sous l'aspect de l'intégralité (selon l'ampleur, la clarté, l'applicabilité etc) de la réglementation juridique de l'institution
} 
Consoante nota Ancel, essa seria a função primeira, desde a Antiguidade, quando se pensava em termos de comparação de instituições ${ }^{22}$ - mirava-se sempre no legislador e em suas tarefas. De fato, "as contribuições da investigação comparativa podem constituir a orientação mais útil e o freio mais eficaz para fantasia, às vezes desenfreada demais, os legisladores nacionais". ${ }^{23}$ Não sem motivo, Pegoraro afirma que "antes de tudo, os resultados dos estudos comparados são, mais do que úteis, indispensáveis no âmbito da elaboração legislativa. (...) Raramente, um projeto de lei é redigido sem que previamente se tenham consultado as experiências desenvolvidas em outros ordenamentos". 24

O legislador pode, então, encontrar nos resultados de um trabalho de direito comparado uma ferramenta para melhor direcionar a norma que pretende ver vigente na sociedade, conforme os interesses que defenda e os benefícios que busque. No próprio cenário de luta política, que sãos os Parlamentos, os contendores estão aptos a utilizar do direito comparado como arma de combate e fonte para os argumentos políticos em uma dada direção ou outra. Nessa medida, podem, por exemplo, escondendo os conhecimentos que têm sobre o direito comparado, propor redações e conteúdos normativos em projetos de lei ou alterações constitucionais de modo a buscar efeitos distintos daqueles que deveriam resultar do projeto - isso porque conhecem a experiência de regras similares em outros países. Em resumo, tomar

faisant l'objet de l'étude, c'est-à-dire du point de vue de la technique, de la politique et de la clinique juridiques, ou bien sous l'aspect de la valeur et des conséquences sociales résultant de la réglementation juridique de l'institution étudiée". BLAGOJEVIC, Borislav T. La méthode comparative juridique. In: ROTONDI, M. (Ed.). Buts et méthodes du droit comparé. Padova: CEDAM; New York: Oceana Publications, 1973. (Série Inchieste di diritto comparato), p. 35.

${ }^{22}$ Tradução nossa do original: "las aportaciones de la investigación comparativa pueden constituir la orientación más útil y el freno más eficaz para la fantasía, a veces demasiado desenfrenada, de los legisladores nacionales". ANCEL, Marc. Utilidade e métodos do direito comparado, cit., p. 18.

${ }^{23}$ DI RUFFIA, Polo Biscaretti. Introducción al derecho constitucional comparado. Las formas de estado y las formas de gobierno. Las constituciones modernas. Traducción de Héctor Fix Zamudio. México: Fondo de Cultura Económica, 1979, p. 15.

${ }^{24}$ Tradução nossa do original: "antes que nada, los resultados de los estudios comparados son, más que útiles, indispensables en el ámbito de la elaboración legislativa. (...) Raramente, un proyecto de ley se redacta sin que previamente se hayan consultado las experiencias desarrolladas en otros ordenamientos". PEGORARO, Lucio. El método en el derecho constitucional..., cit., p. 17. No mesmo sentido, ver ZWEIGERT, Konrad; KÖTZ, Hein. Introduction to comparative law, cit., p. 16; DAVID,

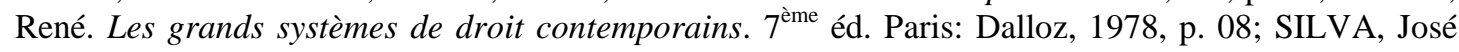
Afonso da. Um pouco de direito constitucional comparado, cit., p. 29. Ainda nessa linha, com uma visão institucional política, Tocqueville argumentava a favor do conhecimento de outras realidades nacionais, especificamente a estadunidense: "No solamente para satisfacer una curiosidad, por otra parte muy legítima, he examinado la América; quise encontrar en ella enseñanzas que pudiésemos aprovechar". TOCQUEVILLE, Alexis de. La democracia en America. Tradução de Luis R. Cuéllar. 2. ed. México: Fondo de Cultura Económica, 2002, p. 39. 
contato com pesquisas comparativas fomenta as próprias estratégias de combate político.

Esta tese corresponde, em última instância, a uma aposta institucional. Procuram-se elementos e pontos de apoio teórico-prático para uma reforma da democracia brasileira. Essa perspectiva reveste-se em si de um caráter conservador; afinal, como lembra Saramago, reformar algo "não é mais que mudar o suficiente para que tudo se mantenha igual". ${ }^{25}$ Apesar disso, acreditamos que existem mudanças institucionais que podem incentivar processos políticos importantes. Diga-se, a engenharia institucional gera efeitos e influencia a maneira como os atores políticos atuam na disputa pelo poder estatal, por isso é um aspecto que não pode ser ignorado. A escolha dessa perspectiva exploratória determina de maneira particular o modo como dar-se-á o desenvolvimento do trabalho, ou seja, a abordagem partirá obrigatoriamente das instituições e de seu funcionamento nas respectivas realidades constitucionais, afastando-se, ao menos de início, de um debate interpretativo hermenêutico que parece ser típico do mundo dos constitucionalistas. ${ }^{26}$

Assim, a finalidade deste trabalho leva em consideração aquilo que, do ponto de vista ideal, constitui os elementos positivos dos institutos de democracia direta, que é incentivar a participação, promover uma cultura de manifestação da cidadania nos assuntos de interesse público, aperfeiçoar a transparência e o controle da política, bem como a possibilidade de dinamizar a ação dos partidos políticos. ${ }^{27}$ É isso o que buscaremos na construção de uma proposta lege ferenda. Obviamente, interessa-nos também encontrar regulações normativas constitucionais que tendam a reduzir alguns riscos típicos vinculados ao uso dos mecanismos de democracia direta, como o aumento da verticalidade das decisões (delegação) a partir de um Poder Executivo

\footnotetext{
${ }^{25}$ SARAMAGO, José. Democracia e universidade. Belém: Editora da UFPA; Lisboa: Fundação José Saramago, 2013, p. 72.

${ }^{26}$ Bercovici faz a seguinte crítica quanto a esse ponto: "Ocorre, no Brasil pós-1988, algo paradoxal: os cientistas políticos e sociólogos buscam, cada vez mais, compreender o funcionamento das instituições e seu regime jurídico-constitucional. Já os constitucionalistas, por sua vez, refugiam-se nos debates sobre a aplicação das normas e da hermenêutica e interpretação constitucionais, tornando o judiciário praticamente o único setor estatal estudado e analisado por um direito público que se pretende democrático, mas não fala de democracia. O risco de uma teoria constitucional sem preocupações com o Estado é o do abandono pela política democrática e partidária, da esfera da constituição". BERCOVICI, Gilberto. Estado intervencionista e Constituição social no Brasil: o silêncio ensurdecedor de um diálogo entre ausentes. In: NETO, Cláudio Pereira de Souza; SARMENTO, Daniel; BINENBOJM, Gustavo (Coords.). Vinte anos da Constituição Federal de 1988. Rio de Janeiro: Lumen Juris, 2009, p. 734-735.

${ }^{27}$ LISSIDINI, Alicia. Democracia directa en latinoamérica..., cit., p. 11.
} 
fortalecido $^{28}$ e a implementação de políticas tendentes a eliminar ou reduzir direitos e garantias fundamentais de minorias sociais que já tradicionalmente têm os seus direitos violados. Adotamos aqui a visão de Vega, para quem a potencial utilização negativa e desvirtuante (disfuncional) dos institutos de participação direta deve ser remediada por uma regulação jurídica adequada. ${ }^{29}$

Conforme destacado, este trabalho procura elaborar uma aposta normativa de caráter lege ferenda com o intuito de aperfeiçoar o arcabouço constitucional brasileiro. Deve-se atentar para o fato de que tal perspectiva pode parecer, à primeira vista, um passo além do razoável, tendo em vista aquilo que se espera, em regra, de uma pesquisa de cunho jurídico. A eleição de uma dada solução normativa para determinado problema não está posta simplesmente pela objetividade do resultado da pesquisa; pelo contrário, envolve a análise política valorativa do pesquisador. Sabemos que elaborar e propor leis não equivale a pesquisá-las, bem como que a tarefa do estudioso é científica, técnica, neutra e objetiva, ao passo que o legislador, enquanto agente político, toma posição ideológico-programática em face da tentativa de influenciar ou mesmo assumir posições estatais. ${ }^{30} \mathrm{Se}$ ambas as situações não podem ser confundidas, significa que o produto de uma pesquisa comparada, em tese, deveria sair das mãos do jurista como um produto praticamente neutro, fruto de um encadeamento intelectual que seguiu os rigores da ciência. Frente a esse produto, o agente político, no caso o legislador, teria que tomar a sua posição, indicando qual o melhor caminho a seguir. A discricionariedade ou arbitrariedade é atributo típico do político, e não do cientista.

Com efeito, ao pesquisador não competiria tomar posições políticas e, nesse sentido, Kennedy observa no campo do direito comparado um esforço para se abster de qualquer identificação com posições ideológicas ou de interesse social, ${ }^{31}$ sintetizando essa conjuntura da seguinte forma: "o direito comparativo hoje é sobre

\footnotetext{
${ }^{28}$ LISSIDINI, Alicia. Democracia directa en latinoamérica..., cit., p. 11.

${ }^{29}$ VEGA, Pedro de. La reforma constitucional y la problematica del poder constituyente. Madrid: Tecnos, 2011, p. 127.

${ }^{30}$ WEBER, Max. Ciência e política: duas vocações. Tradução de Leonidas Hegenberg e Octany Silveira da Mota. São Paulo: Cultrix, 2011, p. 55.

${ }^{31}$ KENNEDY, David. The methods and the politics. In: LEGRAND, Pierre; MUNDAY, Roderick (Eds.). Comparative legal studies: traditions and transitions. Cambridge: Cambridge University Press, 2003, p. 346. Disponível em: <http://www.law.harvard.edu/faculty/dkennedy/publications/DKennedy TheMethodsandThePolitics.pdf $>$. Acesso em: 28 jul. 2016.
} 
conhecer, e não fazer". ${ }^{32}$ Sacco aparenta não negar tal perspectiva, ao dizer que "a comparação é potencialmente imparcial e tem o direito de sê-lo". ${ }^{33}$ Há, portanto, uma preocupação clara em manter certo status de respeito científico.

Escolher a melhor solução (em face de uma realidade particular) envolveria um julgamento de valor, ${ }^{34}$ configurando um elemento subjetivo, o qual diz respeito a opções de cada pessoa. O que seria a melhor solução segundo o juízo de alguém, para outra, com valores e interesses distintos, poderia representar a pior. Tal tipo de procedimento acarretaria a perda de neutralidade e objetividade do trabalho científicojurídico. Constatado isso, não surpreende que Miranda elabore a seguinte assertiva:

Bem entendido, não cabe ao jurista qua tale - naturalmente suscitado a, entre diferentes soluções de problemas iguais, considerar umas melhores que outras promover uma política legislativa, imiscuindo-se num terreno que já não é o seu. Mas não é menos certo que não há política legislativa segura sem o prévio diagnóstico do estado do Direito positivo, para o qual contribui, em medida não desprezível, o que se sabe dos Direitos positivos estrangeiros. E muito poderia dizer-se, mutatis mutandis, sobre a política jurisprudencial. ${ }^{35}$

O discurso da neutralidade é talvez um dos mais conhecidos no âmbito acadêmico; tudo o que se pede, por exemplo, a um professor em sala de aula é que este seja neutro ao ministrar a sua disciplina e deixe os alunos "pensarem por si". Obviamente, aos que demandam esse comportamento de um docente, deveria ser perguntado ao que se referem quando falam em "neutralidade".

Em realidade, nenhum pesquisador ou docente é neutro em seu trabalho a ponto de aparecer frente ao seu objeto de estudo como uma pessoa vazia de ideologia e valores adquiridos socialmente. ${ }^{36}$ Pouco importa aqui se isso se dá de modo

\footnotetext{
32 Tradução nossa do original: "comparative law today is about knowing, not doing". KENNEDY, David. The methods and the politics, cit., p. 346.

${ }^{33}$ SACCO, Rodolfo. Introdução ao direito comparado. Tradução de Véra Jacob de Fradera. São Paulo: Revista dos Tribunais, 2001, p. 27.

34 WHYTOCK, Christopher. Legal origins, functionalism, and the future of comparative law. Bringham Young University Law Review, v. 2009, n. 6, p. 1.887, Feb., 2009.

${ }^{35}$ MIRANDA, Jorge. Sobre o direito constitucional comparado, cit., p. 255.

36 A demanda por uma docência completamente neutra (vazia) equivaleria a uma busca pela "ciência pura" da mesma maneira que se pode desejar encontrar uma arte pura ou arte pela arte. As análises de Benjamin quanto a isso são pertinentes: "Em outras palavras: o valor único da obra de arte 'autêntica' tem sempre um fundamento teológico, por mais remoto que seja: ele pode ser reconhecido, como ritual secularizado, mesmo nas formas mais profanas do culto do Belo. Essas formas profanas do culto do Belo, surgidas na Renascença e vigentes durante três séculos, deixaram manifesto esse fundamento quando sofreram seu primeiro abalo grave. Com efeito, quando o advento da primeira técnica de reprodução verdadeiramente revolucionária - a fotografia, contemporânea do início do socialismo -
} 
consciente ou não. É um requisito próprio da pesquisa científica estar carregado de valores e visões de mundo; assim, Weber argumenta que "apenas as ideias de valor que dominam o investigador e uma época podem determinar o objeto de estudo e os limites desse estudo". ${ }^{37}$ Com efeito, a determinação do objeto de pesquisa e das questões atinentes à problemática depende de forma preponderante dos elementos valorativos que estão preestabelecidos na cabeça de quem vai realizar a empreitada investigativa. Sem tal pressuposto não há pesquisa.

Hegel, em uma passagem excepcional de sua Introdução à filosofia da história universal, capta bem essa visão ao tratar do trabalho científico do historiador:

Por conseguinte, como primeira condição, poderíamos formular a de conceber fielmente o histórico; só que em expressões tão gerais como fielmente e conceber reside a ambiguidade. Também o historiador corrente e mediano, que intenta e pretende conduzir-se apenas à maneira de inventariante, entregando-se somente ao que é dado, não é passivo no seu pensar; traz consigo as suas categorias e vê através delas o existente. O verdadeiro não reside na superfície sensível; em tudo o que singularmente deve ser científico a razão não pode dormir, e há que empregar a reflexão. Quem olha o mundo racionalmente divisa-o também como racional; ambas as coisas se encontram na determinação recíproca. ${ }^{38}$

Convém, então, abandonar desde já a ideia de que é preciso um "sujeito neutro" ou "vazio de convicções" para a realização de um estudo científico qualquer. Em realidade, esse discurso político que demanda neutralidade muitas vezes encobre o seu inverso, pois pode um pesquisador ou professor esconder as suas opiniões e posições sob a forma de uma exposição científica rigorosa e "neutra”. É dentro dessa visão que Weber destaca que a forma mais desleal de se fazer pregação política utilizando-se da posição de professor era camuflar esses objetivos políticos sob o argumento de "deixar os fatos falarem". ${ }^{39}$ Nessa ordem de ideias, Demo sentencia: "a

\footnotetext{
levou a arte a pressentir a proximidade de um crise, que só se fez aprofundar-se nos cem anos seguintes, ela reagiu ao perido iminente com a doutrina da arte pela arte, que é no fundo uma teologia da arte. Dela resultou uma teologia negativa da arte, soba a forma de uma arte pura, que não rejeita apenas toda função social, mas também qualquer determinação objetiva." BENJAMIN, Walter. A obra de arte na era de sua reprodutibilidade técnica. In: BENJAMIN, Walter. Magia e técnica, arte e política: ensaios sobre literatura e história da cultura. Tradução de Sérgio Paulo Rouanet. São Paulo: Brasiliense, 1985, p. 171.

37 WEBER, Max. A "objetividade" do conhecimento nas ciências sociais. In: COHN, Gabriel (Org.); FERNANDES, Florestan (Coord.). Weber: sociologia. Tradução de Amélia Cohn e Gabriel Cohn. São Paulo: Ática, 2008, p. 100.

${ }^{38}$ HEGEL, Georg Wilhelm Friedrich. A razão na história..., cit., p. 33-34.

${ }^{39}$ WEBER, Max. Ciência e política: duas vocações, cit., p. 39.
} 
posição de neutralidade ou é maliciosa, de quem busca aí uma estratégia de aceitação não contestada, ou é ingênua, de quem não percebe o engajamento da neutralidade". ${ }^{4}$

O rigor científico de uma pesquisa em direito comparado não é atingido de maneira impertinente pela falta de neutralidade do pesquisador; nesse ponto, é preciso evitar o discurso de uma separação absoluta entre sujeito e objeto em ciências sociais. Com base nessa perspectiva e sob influência direta do pensamento weberiano, Jansen, apesar de salientar que as análises de uma pesquisa em direito comparado não devem ter um caráter avaliativo, conclui que:

Investigações comparativas são determinadas, por um lado, pela escolha dos objetos comparados e, por outro, pela escolha da questão comparativa (tertium comparationis). Essas escolhas são influenciadas pelos interesses epistêmicos e avaliações sobre o que interessa ou o que conta como normal. Elas deveriam ser abertamente declaradas e poderiam ser medidas tanto pelos padrões não acadêmicos (por exemplo, legais) e acadêmicos relacionados à qualidade do resultado da pesquisa comparativa. $^{41}$

Löwy amplia esse quadro de interferência subjetiva na produção científica (social), afirmando que "os juízos de valor, as ideologias, as visões sociais de mundo, as opções morais etc., jogam um papel não só na seleção do objeto e na formulação da problemática, mas no conjunto da investigação científica, em todo o processo de produção do conhecimento". ${ }^{42}$ Ocorre, dessa forma, que mesmo uma pesquisa em direito comparado que não chegue a conclusões valorativas e não indique qualquer caminho para uma reforma legislativa com vistas a "melhorar" determinado ordenamento nacional está impregnada dessa falta de "neutralidade". ${ }^{3}$

\footnotetext{
${ }_{40}$ DEMO, Pedro. Introdução à metodologia da ciência. 2. ed. São Paulo: Atlas, 2013, p. 74.

${ }^{41}$ Tradução nossa do original: "comparative investigations are determined on the one hand by the choice of objects compared, and on the other by the choice of the comparative question (tertium comparationis). These choices are influenced by epistemic interests and evaluations about what matters on or what counts as normal. They should be openly stated and may be measured by both nonacademic (eg legal) values and academic standards relating to the quality of the result of comparative research". JANSEN, Nils. Comparative law and comparative knowledge, cit., p. 337.

${ }^{42}$ LÖWY, Michael. Ideologias e ciência social: elementos para uma análise marxista. São Paulo: Cortez, 2010, p. 59.

${ }^{43}$ Não vamos entrar aqui em discussão mais detalhada sobre como, muitas vezes, a visão conservadora impregna a metodologia da comparação de direitos partindo de pressupostos políticos e ideológicos precisos que limitam completamente o horizonte da pesquisa. No fundo, trata-se de naturalizar $o$ status quo, que aparece, assim, como ponto de vista "neutro" e "objetivo". Sobre esse aspecto, ver HILL, Jonathan. Comparative law: law reform and legal theory. Oxford Journal of Legal Studies, v. 9, n. 1, p. 106-110, Spring 1989. Disponível em: <http://www.jstor.org/stable/pdf/764340.pdf? = 1470168502182>. Acesso em: $1^{\circ}$ ago. 2016.
} 
Se ao final de uma pesquisa em direito comparado há uma tomada de posição do pesquisador na direção de certa reforma do ordenamento jurídico, a sua contribuição para a política legislativa (não neutra) depende de aspectos vinculados ao conteúdo científico das análises realizadas. Caso um comparatista do direito se arrisque nessa "aposta” política, ele terá que "provar" que, a partir do conteúdo da pesquisa, do método aplicado, dos dados levantados e das interpretações feitas, a elaboração normativa proposta como a "melhor" e mais adequada é a mais pertinente em face de certos objetivos políticos específicos.

O seu teste de rigor, a cientificidade e a "objetividade" se dão pela valoração de seus procedimentos, amplitude, capacidade de análise, tipo de abordagem, perspectiva adotada, e, por fim, pelo embate com outras posições políticas. O direito comparado "em si" não existe, e os seus métodos e resultados de pesquisa podem ir em muitas direções. Ao se considerar que o direito comparado pode oferecer a "melhor opção" normativa, não se conclui que isso diga respeito a um melhor "universal", mas, sim, que afeta determinados grupos sociais, beneficiando certa visão de mundo em detrimento de outras - eis aí o seu aspecto político.

Uma proposta legislativa elaborada a partir de uma pesquisa comparativa deve se mostrar suficientemente fundamentada a ponto de dar o devido suporte à posição política defendida. Com efeito, é necessário haver coerência "objetiva" no procedimento analítico de pesquisa a ponto de levar à conclusão de que o efeito desejado com a proposta legislativa elaborada (lege ferenda) tenha probabilidade $\left(\right.$ aposta $\left.^{44}\right)$ de ser efetivamente alcançado na realidade concreta. Ora, no final deste estudo, procuramos construir alguns apontamentos normativos constitucionais no que diz respeito aos mecanismos de democracia direta, defendendo que estes sejam adotados pelo legislador brasileiro em uma futura reforma da Lei Maior de 1988 ou mesmo durante um novo processo constituinte. Esperamos que essa medida surta efeitos benéficos dentro de certa visão política.

A tese que defendemos neste trabalho é a de que a Constituição brasileira de 1988, quando comparada às suas congêneres venezuelana de 1999 e equatoriana de

\footnotetext{
44 A ideia de "aposta" é utilizada por Matus, o qual estabelece que qualquer forma de planejamento da ação com vistas a um resultado desejado tem como pressuposto a existência de variáveis que o agente planejador não controla, de modo que se deve trabalhar sempre em termos de probabilidade. MATUS, Carlos. O plano como aposta. São Paulo em perspectiva, v. 4, n. 5, p. 28, out.-dez. 1991. Disponível em: <http://www.cgca.com.br/userfiles/file/O\%20Plano\%20Como\%20Aposta\%20por\%20Carlos\%20 Matus.pdf $>$. Acesso em: 20 nov. 2016.
} 
2008, traz em seu conteúdo um desenho normativo conservador em termos de instrumentos de mecanismos de democracia direta, o que significa dizer que estes: (i) não são uma via capaz de gerar bloqueios políticos (controle democrático) para medidas de caráter antipopular; (ii) não constituem potenciais saídas para amenizar crises políticas e evitar violações ao regime democrático institucional; (iii) têm grande potencial de serem utilizados de modo a implementar políticas populistas ${ }^{45}$ tendentes a pôr em risco direitos e garantias fundamentais; e (iv) têm pouca capacidade de gerar incentivo à construção de uma democracia de alta intensidade (participativa). Na análise comparativa, verificaremos também que a Constituição brasileira de 1988 se aproxima da realidade constitucional espanhola de 1978 em termos formais e de experiência, embora haja algumas distinções importantes.

É diante dessa construção crítica que iremos propor alguns caminhos a serem seguidos em uma possível reforma do ordenamento constitucional brasileiro (considerando, inclusive, perspectivas infraconstitucionais), de modo a potencializar os efeitos benéficos desses instrumentos e neutralizar os seus defeitos na atual regulação. Reforce-se que não apresentamos uma proposta de reforma constitucional acabada e detalhada, mas que simplesmente realizaremos apontamentos nesse sentido a partir da análise comparativa.

Ao defendermos a reforma da Constituição de 1988, com vistas a se ter uma melhor estrutura normativa dos instrumentos de democracia direta, não estamos dizendo que esta deva ser a primeira das reformas ou a mais importante, mas apenas que ela se faz necessária. Não parece prudente ignorar os mecanismos de democracia direta.

\footnotetext{
${ }^{45}$ Uma das expressões mais comuns de um populismo que atinge direitos e garantias fundamentais se dá no campo criminal (o que corresponde a um populismo de direita). Ao tecer considerações sobre a situação política italiana, Ferrajoli adverte que: "En el síndrome de la derecha italiana el enemigo tiene rostros diversos, geográficos, sociales, políticos o culturales: el Sur respecto del Norte, los inmigrantes clandestinos, los delincuentes callejeros, los comunistas, la oposición, la prensa libre, lo intelectuales, el sindicato (...). Itália está convirtiéndose en un país envenenado por el miedo, por el odio a los diferentes y por el desprecio de los débiles. Miedo y racismo, sospecha y desconfianza hacia los diversos, inseguridad y agresividad social han sido, en estos años, intensamente alimentados por la demagogia de la seguridad de las derechas, a la que las izquierdas han sido en gran medida subalternas. El miedo ha sido siempre un recurso del poder político: puede producirlo él mismo, como en los regímenes abiertamente autoritarios, o servirse de él, secundándolo o alimentándolo con objeto de obtener consenso y legitimación, con el las campañas populistas de apoyo a medidas penales tan duramente represivas como inútiles e ineficaces. (...) Es inútil decir que los principales blancos del populismo penal son los immigrantes, contra los que se han publicado leyes duramente represivas y discriminatorias". FERRAJOLI, Luigi. Poderes salvajes, cit., p. 68.
} 
Definido o objeto, as finalidades e a tese do estudo que segue, convém fazer alguns apontamentos sobre as dimensões da abordagem científica da pesquisa. Para chegarmos aos resultados críticos desejados, vamos considerar não só como as regras são previstas mas também o modo como são aplicadas. Em outros termos, a comparação textual das normas constitucionais que instituem os mecanismos de democracia direta e as suas respectivas regulamentações infraconstitucionais não nos fornece todos os elementos pertinentes para uma valoração quanto às "melhores soluções" normativas adequadas à realidade brasileira. É importante fugir do puro formalismo jurídico, uma vez que os mecanismos de democracia direta não podem ser analisados unicamente a partir das regras constitucionais que os reconhecem. ${ }^{46}$ Nesse sentido, devemos nos perguntar como funcionam concretamente os mecanismos que têm o intuito de promover a democracia direta em países como Espanha, Brasil, Venezuela e Equador.

Quanto à análise a ser realizada, mais uma dimensão é importante, qual seja, a dos contextos gerais. Se os problemas enfrentados pelos diversos países não forem similares, ou seja, tiverem certas particularidades relevantes que os diferenciem, a procura a partir do método comparativo por uma melhor solução normativa para esses problemas será muito difícil. O que tem potencial de ser uma ótima solução dentro de um ordenamento constitucional, talvez se mostre uma escolha inadequada para outro: "uma solução jurídica que efetivamente mitiga um problema em uma sociedade pode não ser apropriada para outra se o problema sendo resolvido naquela é diferente daquele que precisa de solução nessa". ${ }^{47}$

Realmente, quanto a esse ponto, pode-se imaginar que os problemas são idênticos, ou melhor, universais, enquanto na realidade não o são, e isso tem o potencial de comprometer o resultado de qualquer pesquisa que busque as melhores soluções para situações concretas. Assim, "se se pensar que os problemas são universais, então, deve-se pensar que em tipos de sociedade similares os meios

\footnotetext{
${ }^{46}$ BARRIENTOS, Francisco Soto. El referédum en latinoamérica: un análisis desde el derecho comparado. Boletin Mexicano de Derecho Comparado, Universidad Nacional Autónoma de México, Ciudad de México, v. 46, n. 136, p. 318, enero-abr. 2013. Disponível em: <http://www.redalyc.org/articulo.oa?id=42725646009>. Acesso em: 12 abr. 2015.

${ }^{47}$ Tradução nossa do original: "a legal solution that effectively mitigates a problem in one society might not be appropriate for another society if the problem being solved in the former is different from the problem that needs to be solved in the latter". WHYTOCK, Christopher. Legal origins, functionalism, and the future of comparative law, cit, p. 1.886 .
} 
jurídicos para responder esses problemas produzirão os mesmos resultados". ${ }^{48} \mathrm{~A}$ problemática aqui é a tendência de universalização dos problemas e das soluções. ${ }^{49}$

Não levar em conta o contexto no processo de análise comparativa, principalmente os elementos que compõem o quadro socioeconômico, pode redundar em uma visão incompleta e distorcida das realidades confrontadas, ${ }^{50}$ uma vez que as particularidades contextuais têm um efeito importante sobre as normas a serem aplicadas. "A mesma regra jurídica pode produzir diferentes resultados em diferentes países (e, talvez, resultados irrelevantes em alguns países) devido a esses fatores contextuais". ${ }^{51}$ Com efeito, a finalidade objetivada com a aplicação de determinada norma acaba encontrando um resultado diverso e, muitas vezes, não desejado quando implementada em realidades diversas. ${ }^{52}$ Em síntese, as regras jurídicas não podem ser completamente compreendidas se isoladas de seu contexto. ${ }^{53}$

Dessarte, para falar dos possíveis efeitos da melhor solução normativa, devemos levar em conta o contexto econômico, político, social e cultural de cada realidade estatal estudada: “... sem entender as interações potencialmente complexas entre as regras jurídicas e os fatores contextuais, é difícil estimar os efeitos causais das regras jurídicas com um nível útil de certeza". ${ }^{54}$ Em resumo, para realizar a análise do direito constitucional comparado, é preciso considerar a "evolução

\footnotetext{
${ }^{48}$ Tradução nossa do original: "if one thinks that problems are universal, then one has to think also that in similar types of societies the legal ways to respond these problems will produce quite similar results". HUSA, Jaakko. About the methodology of comparative law - some comments concerning the Wonderland... Maastricht: Maastricht Faculty of Law Working Paper, 2007, p. 09.

${ }^{49}$ Nesse sentido, Zweigert assevera que "nous constatons que dans différents ordres juridiques les mêmes tâches son remplies de la même facón, et cela malgré des différences de structure dogmatique...". ${ }^{49}$ ZWEIGERT, Konrad. Des solutions identiques par des voies différentes - quelques observations en matière de droit comparé. Revue Internationale de Droit Comparé, v. 18, n. 1, p. 16, janv.-mars 1966.

${ }_{50}$ ACUÑA, Roger Merino. Comparative law from below. The construction of a critical project in comparative legal studies. Saarbrücken: Lampert, 2012, p. 17.

${ }^{51}$ Tradução nossa do original: "The same legal rule may produce different results in different countries (and perhaps no significant results in some countries) due to such contextual factors". WHYTOCK, Christopher. Legal origins, functionalism, and the future of comparative law, cit., p. 1.898.

${ }^{52}$ BRAND, Oliver. Conceptual comparisons: towards a coherent methodology of comparative legal studies. Brooklyn Journal of International Law, Brooklyn Law School, v. 32, n. 2, p. 415, 2007.

53 PONTHOREAU, Marie-Claire. Le droit comparé en question(s): entre pragmatisme et outil épistemologique. Revue Internacionale de Droit Comparé, v. 57, n. 1, p. 14, 2005.

${ }^{54}$ Tradução nossa do original: “... without understanding the potentially complex interactions between legal rules and contextual factors, it is difficult to estimate the causal effects of legal rules with a useful degree of certainty". WHYTOCK, Christopher. Legal origins, functionalism, and the future of comparative law, cit., p. 1.899. Com a mesma perspectiva, vamos o que Jackson e Tushnet dizem: "Here comparativism brings to the fore the need to see particular legal institutions and doctrines in the political, legal, economic, and social contexts in which they are found." JACKSON, Vicki C.; TUSHNET, Mark. Defining the field of comparative constitutional law. Praeger Publishers: Westport, Connectcut, 2002, p. 12.
} 
jurídico-política e a realidade do país", ${ }^{55}$ a fim de se evitar erros de análise. ${ }^{56}$ Como reforça Hirschl, "constituições não se originam e nem operam no vácuo. Sua importância não pode ser descrita ou explicada com algum significado se independente de forças sociais, políticas e econômicas, ambas domésticas e internacionais, que as moldam". 57

Resulta evidente também que nenhuma análise em direito comparado pode tomar todos os fatores contextuais existentes nem "pode explicar todos os fatores contextuais relevantes - isso seria um padrão irreal". ${ }^{58}$ Seria tarefa igualmente impossível submergir de maneira plena em uma cultura estrangeira visando compreender completamente as suas regras jurídicas. ${ }^{59} \mathrm{O}$ pesquisador, na medida do possível, deve se cercar de procedimentos que busquem apreender o máximo dos elementos contextuais que influenciam a aplicação da regra jurídica submetida a estudo. É necessário tentar refletir sobre o movimento real da aplicação de uma norma em determinada sociedade considerando o seu contexto. Em um estudo de direito comparado, não se encontram problemas e possíveis soluções universais, mas, sim, perspectivas jurídicas para situações particulares. Os argumentos trazidos anteriormente dão sustentação para que esse projeto investigativo trilhe caminhos capazes de ultrapassar o campo das análises estritamente jurídicas, sem, contudo, perder o foco jurídico-constitucional, na medida em que só a lógica jurídica não é

\footnotetext{
55 Tradução nossa do original: "evolución jurídico-política y la realidad del país". CARPIZO, Jorge. Derecho constitucional latinoamericano y comparado, cit., p. 950.

56 Parece ser essa a perspectiva do alerta de Ancel: "Existe, é certo, uma verdade manifesta, mas que talvez se tenha perdido de vista; e nós não devemos esquecer os erros ou as aproximações prematuras que foram feitas em estudos que se desejavam como de direito comparado, vale dizer, horizontais, sem estudo vertical preliminar suficiente". ANCEL, Marc. Utilidade e métodos do direito comparado, cit., p. 109. Com uma compreensão mais específica, Cruz afirma: "A final error that comparatist has to guard against is not to overlook 'extra-legal' factors, which may be informal customs and practices, which operate outside strict law, or various non-legal phenomena, which ultimately influence the state of the law. One of the benefits of the effective utilisation of the comparative law methodology is to deepen and widen one's knowledge of the social and economic milieu within a legal system and legal rules operate". CRUZ, Peter de. Comparative law in a changing world, cit., p. 230.

57 Tradução nossa do original: "constitutions neighter originate nor operate in a vacuum. Their important cannot be meaningfully described or explained independent of the social, political, and economic forces, both domestic and international, that shape them". HIRSCHL, Ran. Comparative matters: the renaissance of comparative constitutional law. New York: Oxford University Press, 2014, p. 152.

${ }^{58}$ Tradução nossa do original: "no analysis can account for all relevant contextual factors - that would be an unrealistic standard". WHYTOCK, Christopher. Legal origins, functionalism, and the future of comparative law, cit., p. 1.903.

${ }^{59}$ BRAND, Oliver. Conceptual comparisons..., cit., p. 414.
} 
capaz explicar os fenômenos do direito ${ }^{60}$ - a não ser que se queira uma compreensão puramente formalista. Por isso, é preciso levar a sério o alerta de MirkineGuetzévitch, "O desconhecimento das regras jurídicas certamente é bem perigoso, mas não menos perigosos são os abusos e os excessos do direito" ${ }^{61}$ Como também pontua Di Ruffia “as exigências específicas da investigação comparativa no âmbito do direito constitucional impõem, além disso, a utilização das contribuições de várias ciências não jurídicas que se referem, igualmente, aos ordenamentos estatais". ${ }^{62}$ Nas palavras de Jackson e Tushnet, "a função do Direito constitucional e do Direito constitucional comparado não pode ocorrer em isolamento intelectual dos trabalhos de outras disciplinas da ciência política, da sociologia, da antropologia cultural, das ciências cognitivas ou das ciências econômicas". ${ }^{63}$

Assim, é pertinente notar que a ciência política será fundamental para o desenvolvimento da pesquisa proposta, uma vez que nesse campo investigativo há uma relevante gama de análises sobre os mecanismos de democracia direta e ponderações sobre os seus potenciais efeitos.

Elaboradas essas considerações introdutórias, convém rapidamente apontar a estrutura geral do estudo que segue. A primeira parte do trabalho é composta de três capítulos que procuram demarcar as discussões práticas e teóricas a respeito dos mecanismos de democracia direta. Trata-se de uma aproximação inicial com o tema, algo essencial para a abordagem comparativa. Assim, no Capítulo 1 tratamos o modo

\footnotetext{
${ }^{60}$ Nesse sentido, Mirkine-Guetzévitch afirma que “une loi n'est jamais une raison écrite. Elle est un compromis dans la lutte des groupes, des partis, des individus. Historiquement, la loi est toujours une transaction. C'est porquoi la logique juridique seule n'est pas capable d'expliquer le droit". MIRKINEGUETZÉVITCH, Boris. Les méthodes d'étude du droit constitutionnel comparé. Revue Internationale de Droit Comparé, v. 1, n. 4, p. 401, oct.-déc. 1949.

${ }^{61}$ Tradução nossa do original: "La méconnaissance des règles juridiques est certes bien dangereuse; non moins dangereux cependant sont les abus et les excès du droit". MIRKINE-GUETZÉVITCH, Boris. Les méthodes d'étude du droit constitutionnel comparé, cit., p. 398.

62 Tradução nossa do original: "las exigencias específicas de la investigación comparativa en el ámbito del derecho constitucional imponen, además, la utilización de las aportaciones de varias ciencias no jurídicas que se referien, igualmente, a los ordenamientos estatales". DI RUFFIA, Polo Biscaretti. Introducción al derecho constitucional comparado, cit., p. 23. No mesmo sentido, Pegoraro assevera: "En resumen, el Derecho Comparado y, dentro de este ámbito, el Derecho Público Comparado posee autonomia respecto de otras ciencias. No obstante lo cual, no puede dejar de utilizar al mismo tiempo o por separado la Historia Jurídica, la Historia de las Doctrinas Políticas, la Ciencia Política, la Filosofia, la Sociologia del Derecho y otras ramas del saber". PEGORARO, Lucio. El método en el derecho constitucional..., cit., p. 23. Ver também MIRKINE-GUETZÉVITCH, Boris. Les méthodes d'étude du droit constitutionnel comparé, cit., p. 397.

${ }^{63}$ Tradução nossa do original: "the work of constitutional law and comparative constitutional law cannot carry forward in intellectual isolation from the work of other disciplines of political science, sociology, cultural antropology, the cognitive sciences, or economics". JACKSON, Vicki C.; TUSHNET, Mark. Defining the field of comparative constitutional law. Westport, CT: Praeger, 2002, p. 12.
} 
como os mecanismos de democracia direta encontram o seu lugar dentro do sistema representativo. Já no 2 Capítulo expomos pormenorizadamente alguns conceitos vinculados ao tema da democracia e da participação direta, abordando as modalidades tradicionais dos mecanismos de democracia direta e as suas características principais. No Capítulo 3, por sua vez, trazemos algumas controvérsias que têm dado ensejo a um grande debate sobre os riscos trazidos pelos institutos de democracia direta.

A segunda parte da pesquisa se dedica ao exame individualizado do regime constitucional equatoriano de 2008 (Capítulo 4), venezuelano de 1999 (Capítulo 5), espanhol de 1978 (Capítulo 6) e brasileiro de 1988 (Capítulo 7). Lançamos um olhar atento sobre as regulações constitucionais atinentes aos mecanismos de democracia direta, levando em conta a estrutura de cada Constituição, as regras infraconstitucionais e o modo como esses institutos foram concebidos e aplicados, além de versar sobre as críticas que receberam. Ressalte-se que todas essas questões são examinadas à luz da tradição constitucional de cada país e de seu contexto sóciohistórico.

Por fim, no Capítulo 8 elaboramos análises comparativas pontuais entre os quatro países estudados, procurando dar fundamento a algumas propostas gerais de reforma à atual regulação Constitucional brasileira de 1988 no que diz respeito aos mecanismos de democracia direta. 


\section{INTRODUCCIÓN}

De un modo de visión ideal, la democracia tiene por base el principio de que un pueblo tiene el derecho de auto gobernarse, elijir su proprio destino. Igualdad, libertad y soberania estan en plena sintonia. Pero la democracia, vista como expresión de una estructura de dominación política, debe constituirse como una institucionalidad capaz de dar vida a las relaciones sociales de poder particularizadas. En otras palabras, se hace siempre necesario definir los caminos que deben ser seguidos al lo largo de los procesos de decisión sobre cuestiones que sean al respecto del destino de toda la comunidad. De un principio genérico y abstracto, el cual define que la titularidad del poder vendría de los integrantes de un grupo político, es necesario llegar a la condición de acción efectiva, una vez que existe un espacio a ser per corrido entre la titularidad del poder (potencia) y su ejercicio. ${ }^{64}$

Si por un lado la democracia moderna es marcada por la existencia de lo procesos electorales para la elección de representantes que asumen la responsabilidad por las decisiones políticas en el cuotidiano, conduciendo el maquinaria estatal, por otro lado existe la presencia perturbadora de los mecanismos de democracia directa posibilitando que, en situaciones pontuales y excepcionales, la ciudadanía adopte por una posición sobre determinada cuestión política que tenga ganado relevancia. Se impide verificar que la elaboración y la introducción de mecanismos de democracia directa, por ejemplo, referendos y plebiscitos, ocurren como una respuesta a los problemas (o crisis) vivenciados por la representación política. ${ }^{65}$

La ineficiencia, ineficacia e inefectividad de la actividad política en crear situaciones sociales y económicas estables y seguras para grande parte de las populaciones en los Estados contemporáneos hace con que tenga cada vez más desconfianza de los representantes políticos y del propio sistema representativo. El raciocinio cuanto a ese aspecto es simples: los agentes políticos son incapaces de siempre buscar o expresar de modo confiable el interés público y el bien común; al

\footnotetext{
${ }^{64}$ SARTORI, Giovanni. Homo videns: televisão e pós-pensamento. Tradução de Antonio Angonese. São Paulo: Edusc, 2001, p. 108.

${ }^{65}$ EULE, Julian N. Judicial review of direct democracy. The Yale Law Journal, v. 99, n. 7, p. 1.512, May 1990. Disponível em: 〈http://www.jstor.org/stable/pdf/796652.pdf〉. Acesso em: 10 jan. 2015; LISSIDINI, Alicia. Democracia directa en latinoamérica: entre la delegación y la participación. Buenos Aires: Consejo Latinoamericano de Ciencias Sociales - CLACSO, 2011, p. 42; COOTER, Robert D.; GILBERT, Michael D. A theory of direct democracy and the single subject rule. Columbia Law Review, v. 110, n. 3, p. 694, Apr. 2010; AGESTA, Luis Sánchez. Curso de derecho constitucional comparado. Madrid: Universidad de Madrid, 1980, p. 184.
} 
revés, estan siempre aptos a se guiaren por sus propios intereses particulares o de elites económicas muchas veces raras a la ciudadanía. Con efecto, conferir las ciudadanas y ciudadanos la competencia para tomaren directamente decisiones políticas surge como una tentativa de neutralizar los defectos demostrados por la representación política, así todo indica que la insatisfacción estaría en el origen de la demanda por la participación directa ${ }^{66}$.

Como una especie de correctivo o remedio amargo a los problemas evidenciados por la representación política, los mecanismos de la democracia directa estan presentes hoy en grande parte de los ordenamientos constitucionales democráticos. Delante de eso, Svensson afirma que pocos países no previenen algún tipo del instituto de la participación directa de la ciudadanía, si no en un nivel nacional, al menos en nivel local. ${ }^{67}$ Se constata, entonces, que la existencia de los institutos de la participación directa son una realidad jurídica incuestionable, mismo que pueda encontrar objeciones sobre la compatibilidad o mismo la pertinencia de esos institutos en ambiente representativo.

Una vez disponibles para uso en los diversos países que los adoptan, existe una tendencia general de colocar los institutos de democracia directa en práctica. Esa circunstancia se ve aprofundada cuando imaginamos que las crisis vivenciadas en el ámbito de los sistemas representativos buscan ser permanentes, ${ }^{68}$ correspondiendo, de ese modo, a un estagio ordinario de las democracias contemporáneas, y no a una circunstancia excepcional a conturbar el ambiente político. Ese retrato amplio se muestra presente en el análisis de Maduz: “el aumento recién observado en el uso de instrumentos democráticos directos en diferentes regiones del mundo (referendos y proyectos de iniciativa popular), bien como la incorporación de dispositivos

66 CANOTILHO, José Joaquim Gomes. "Brancosos" e interconstitucionalidade: itinerários dos discursos sobre a historicidade constitucional. $2^{\mathrm{a}}$ ed. Coimbra: Almedina, 2012, p. 313.

${ }^{67}$ SVENSSON, Palle. Forms and terminology of direct democracy. Paper presented at the Conference of IPSA and ECPR, São Paulo, 2011, p. 03. Disponível em <http://paperroom.ipsa.org/ papers/paper_26306.pdf>. Acesso em: $1^{\circ}$ fev. 2015.

${ }^{68}$ Pode parecer algo contraditório, mas essa situação se vincula à própria expansão dos sistemas de democracia representativa no mundo. Sobre esse aspecto, vejamos as análises de Altman: "The importance of direct democracy in current debate in the discipline is enhanced by the fact that 'normal' electoral politics are problematic. Today, this debate is even more intense because we face two contradictory scenarios. On the one hand, never more than before have so many people around the globe been free to elect their leaders in a democratic manner. On the other hand, more often than not, democratic performance seems to be challenged by the emergence of public disaffection, weak rule of law, the corruption (both real and assumed) of elected officials, an increasing gap between the rich and the poor, a lack of accountability and transparency, and the continuous marginalization of important groups in society, among other factors". ALTMAN, David. Direct democracy worldwide. New York: Cambridge University Press, 2011, p. 33. 
relacionados a un número de nuevas constituciones, explica el creciente interés en el tema". 69

Se nota que, de acuerdo de cada ordenamiento jurídico nacional, observaremos una diversidad de dibujos normativos de los mecanismos de la democracia directa más que eso, como es obvio, cada realidad en que será implementada la participación directa de los ciudadanos sufre también variación. Así, la discusión que parece estar puesta en el horizonte es exactamente cuanto al uso y efectos de los institutos de participación directa en el contexto democrático. De fato, estos pueden desempeñar muchos papeles en el campo político dependiendo de las formas como son previstos normativamente y delante de la conjetura en que son aplicados. ${ }^{70}$ Con efecto, uno de los debates más importantes de la actual agenda jurídico-política es la necesidad de discutir los potenciales beneficios y riesgos de esas instituciones, ${ }^{71}$ principalmente reconociendo vivencias de crisis económicas y sociales por la cual pasamos en los últimos tiempos. A principio, podemos universalizar la afirmación de Cronin de que los mecanismos de democracia directa llegaron para quedar; pero, mejorías todavía no son necesarias para remediar posibles abusos y efectos negativos en su aplicación. ${ }^{72}$

Dessarte, considerando las reales potencialidades de los mecanismos de democracia directa, es necesario pensar críticamente en los mejores dibujos

\footnotetext{
69 Tradução nossa do original: "the recently observed increase in the use of direct democratic instruments in different regions of the word (referendums and initiatives), as well as the incorporation of related provisions in a number of new constitutions, explains the growing interest in the subject matter". MADUZ, Linda. Direct democracy. Living Reviews in Democracy, ETH Zurich and University of Zurich, v. 2, p. 02, 2010.

${ }^{70}$ Nesse sentido diz Canotilho particularmente sobre os referendos: "O referendo, ou melhor, os vários tipos de refendo podem desempenhar várias funções no sistema político, consoante a sua regulação normativa, o tipo de estdo (unitário, federal), os sistemas eleitorais, os sistemas de partidos e a cultura política.” CANOTILHO, José Joaquim Gomes. “Brancosos" e interconstitucionalidade: itinerários dos discursos sobre a historicidade constitucional..., cit., p. 303. Nos últimos anos, a potencialidade dos mecanismos de democracia direta foi posta à prova na Europa, servindo de instrumento de reação popular contra medidas pró-mercado e de austeridade. Pisarello lembra algumas dessas experiências: "Así, por ejemplo, los referendos conquistados y ganados por la ciudadanía islandesa en contra de los intereses de las entidades financeiras y de la clase política responsable por la generación de la crisis. Del referéndum esloveno promovido por diferentes organizaciones sindicales para rechazar la regresiva reforma de las pensiones impulsada por el Gobierno. O de los referendos italianos que consiguieron detener la privatización del agua, el regreso de la energía nuclear o el mantenimiento de privilegios procesales para ciertos cargos del Estado, y cuyo valor constituyente no puede subestimarse". PISARELLO, Gerardo. Un largo termidor. La ofensiva del constitucionalismo antidemocrático. Madrid: Editorial Trotta, 2011, p. 210.

${ }^{71}$ GARETTO, Daniel Zovatto. Las instituciones de la democracia directa a nivel nacional en América Latina: un balance comparado: 1978-2007. Revista de Derecho Electoral, n. 4, Tribunal Supremo de Elecciones, San José, p. 04, 2. sem. 2007.

72 CRONIN, E. Thomas. Direct democracy. The politics of initiative, referendum, and recall. Harvard University Press, 1999, p. 232. Falamos em universalização da afirmação de Cronin na medida em que esse autor trata especificamente da situação dos mecanismos de democracia direta nos Estados Unidos.
} 
normativos al respecto de la legitimidad democrática de las decisiones políticas del Estado. En las palabras de Garetto, "si los mecanismos de la democracia directa son debidamente utilizados, pueden ayudar a contrariar la tendencia a la deslegitimización del sistema político". ${ }^{73}$ Con perspectiva similar Canotilho afirma que el referendo, una vez "constitucionalmente regulado, puede y debe considerar-se cómo un modo instrumental de dinamización de la democracia política" 74 , siendo que "su positivación constitucional puede emprestar la previsible calculabilidad, transparencia y seguridad" ${ }^{27}$.

Con efecto, esta pesquisa adopta el punto de vista de la necesidad de adaptación de la democracia representativa a las demandas políticas de la sociedad, esta última cada vez más diversa y complexa, siendo los mecanismos de democracia directa instrumentos importantes para la realización de ese ajuste. 76 La construcción de un constitucionalismo democrático pasa por la combinación de formas de participación directa y representativa.77 Desde ahora se resalta que no alimentamos cualquier tipo de ilusión cuanto a la intervención directa de la ciudadanía en esfera política, del mismo modo que no tenemos grandes expectativas cuanto a la representación política. En ese sentido, concordamos con Ferrajoli, que dice que la idea de una "voluntad popular buena es una ilusión",78 colocando que tampoco esta es naturalmente mala.

Con lo hablado, en el trabajo que sigue, vamos nos aprofundar a respecto de los mecanismos de la democracia directa establecidos en el ámbito del actual constitucionalismo latino-americano y europeo, particularmente aquellos previstos en la Constitución española de 1978, brasileña de 1988, venezolana de 1999 y ecuatoriana de 2008. Se trata, con efecto, de un estudio jurídico-constitucional de

\footnotetext{
73 Tradução nossa do original: "si los mecanismos de democracia directa son debidamente utilizados pueden ayudar a contrarrestar la tendencia a la delegitimación del sistema político". GARETTO, Daniel Zovatto. Las instituciones de la democracia directa a nivel nacional en América Latina..., cit., p. 49.

74 CANOTILHO, José Joaquim Gomes. "Brancosos" e interconstitucionalidade: itinerários dos discursos sobre a historicidade constitucional..., cit., p. 306.

75 CANOTILHO, José Joaquim Gomes. “Brancosos” e interconstitucionalidade: itinerários dos discursos sobre a historicidade constitucional..., cit., p. 306.

${ }^{76}$ LISSIDINI, Alicia. Democracia directa en latinoamérica..., cit., p. 20.

77 PISARELLO, Gerardo. Un largo termidor, cit., p. 211.

78 FERRAJOLI, Luigi. Poderes salvajes. La crisis de la democracia constitucional. Tradução de Andrés Ibánez. Madrid: Editorial Trotta, 2011, p. 65.
} 
naturaleza comparativa, ${ }^{79}$ o sea, se busca, en primer plan de desarrollo del trabajo científico, buscar semejanzas o diferencias, afinidades o repulsas entre los institutos de derecho político sometidos en análisis. ${ }^{80}$

En el horizonte investigativo, encontramos construcciones normativas presentes en ordenamientos constitucionales distintos, pero que guardan cierto grado de parentesco. Sobre ese aspecto, conviene observar que el desdoblamiento de toda la pesquisa en el ámbito del derecho comparado exige, como presupuesto lógico, el mínimo de similaridad o analogía entre los institutos en estudio, o sea, existe la necesidad de que los objetos sean comparables. ${ }^{81}$ Seria inapropiada la comparación de objetos de la naturaleza y significados distintos.

En esa orden de ideas, este trabajo está centrado en dos formas de expresión concreta de los mecanismos de democracia directa: (i) todas las modalidades de consultas sometidas a la manifestación popular directa e inmediata que digan a respecto a una reforma constitucional, de leí o expedición de medida administrativa o acto politico, abrangiendo también las consultas que tengan por objetivo la revocación de una leí vigente, independiente de la nomenclatura que esas consultas recibieron en las diversas órdenes constitucionales (consulta popular, referendo o plebiscito); (ii)

\footnotetext{
${ }^{79} \mathrm{Na}$ definição temática da proposta desta tese, utilizamos a terminologia "direito comparado". É pertinente notar, entretanto, que é criticável o termo escolhido, uma vez que o direito comparado não configura um campo normativo específico com conteúdo próprio, como o direito civil ou constitucional, mas denota, principalmente, a análise de campos do direito, o que leva alguns a advogarem pela adoção de outras definições mais apropriadas, por exemplo, "comparação de direitos". Embora aceitando a crítica, não significa que tenhamos que abrir mão do termo elegido, pois este está firmemente estabelecido nas discussões científico-jurídicas. Sobre esse ponto, ver CRUZ, Peter de. Comparative law in a changing world. $3^{\text {rd }}$ ed. Edition. London: Routledge-Cavendish, 2007, p. 07.

${ }^{80}$ CARPIZO, Jorge. Derecho constitucional latinoamericano y comparado. Boletín Mexicano de Derecho Comparado, Universidad Nacional Autónoma de México, v. XXXVIII, n. 114, p. 950, sept.dic. 2005; MIRANDA, Jorge. Sobre o direito constitucional comparado. Revista de Direito Constitucional e Internacional, v. 55, ano 14, p. 244, abr.-jun. 2006; ANCEL, Marc. Utilidade e métodos do direito comparado. Tradução de Sérgio José Porto. Porto Alegre: Sergio Antonio Fabris Editor, 1980, p. 44-45. Embora haja um conflito entre os comparatistas quanto a identificar a ideia de "direito comparado" como ciência ou puro método, parece não haver grandes discordâncias no que diz respeito ao aspecto da realização prática da comparação, isto é, que o direito comparado sempre envolve um procedimento metodológico. Nesse sentido, vejamos o que diz Pegoraro: "Derecho Comparado puede reinvindicar la dignidad de ciencia sólo desde que la finalidad que persigue no es otra que la de sistematizar los materiales jurídicos de un ordenamientos con la idea de ofrecer una comparación, de verificar las analogías y las diferencias, de clasificar institutos y sistemas, dando orden al conocimiento y creando modelos dotados de prescritividad". PEGORARO, Lucio. El método en el derecho constitucional: la perspectiva desde el derecho comparado. Revista de Estudios Políticos (Nueva Época), n. 112, p. 14, abr.-jun. 2001.

${ }^{81}$ ZWEIGERT, Konrad; KÖTZ, Hein. Introduction to comparative law. $3^{\text {rd }}$ ed. rev. Tradução de Tony Weir. Oxford: Claredon Press, 1998, p. 15; PEGORARO, Lucio. El método en el derecho constitucional..., cit., p. 15; DUVERGER, Maurice. Metodos de las ciencias sociales. Tradução de Alfonso Sureda. Barcelona: Ariel, 1980, p. 412-413; SILVA, José Afonso da. Um pouco de direito constitucional comparado. Três projetos de Constituição. São Paulo: Malheiros, 2009, p. 21.
} 
todas las formas de iniciativa fundadas en la petición de fracción de los electores en el ejercício de competencias constitucionales y que tengan por objetivo la practica de determinada medida, como forzar la realización de la nueva solicitud de elección o consulta para la revocación del mandato politico, la implementación de una consulta popular, la presentación de propuesta legislativa o tema constitucional frente al Poder Legislativo (iniciativa legislativa popular) y la convocación de elecciones para una Asamblea Constituyente.

Es importante resaltar que las analisis se darán particularmente sobre los institutos de aplicación nacional, excluyendo de nuestro campo exploratorio las normas y experiencias de carácter subnacional o local. No significa que vamos ignorar tales reglas y experiencias, pero apenas que no son el foco de nuestras preocupaciones.

Obviamente, la comparación de los institutos de democracia directa presentes en ordenamientos nacionales distintos corresponde tanto a un procedimiento analítico ${ }^{82}$ cuanto a una finalidad inmediata. Debemos afirmar eso de modo redundante, pero necesaria: la finalidad del estudio que sigue es realizar una comparación que tendrá como resultado un análisis comparativo. Entretanto, el estudio irá un poco a más. Con efecto, se debe hacer referencia a un objetivo final de la pesquisa, que es establecer apuntamientos propositivos de orden jurídica pasibles de servir de punto de partida a una futura alteración en la regulación constitucional brasileña de $1988 .{ }^{83}$ De ese modo, estamos en línea al punto de vista de que la pesquisa en derecho comparado tiene un papel importante en el campo de la política legislativa. Aceptando esa perspectiva, Carpizo coloca que el análisis comparada de instituciones constitucionales tiene "la finalidad primordial de examinar cuales de ellas pueden ayudar a fortalecer un sistema constitucional especifico". ${ }^{84}$

\footnotetext{
${ }^{82}$ Como destacam Zweigert e Kötz, o direito comparado corresponde a uma "intellectual activity with law as its object and comparison as its process". ZWEIGERT, Konrad; KÖTZ, Hein. Introduction to comparative law, cit., p. 02.

${ }^{83}$ Não consideramos convenientes análises abstratas sobre quais são "as melhores" e "as piores" instituições. Nesse sentido, Jansen alerta para o fato de que "evaluation of the objects compared is not a part of the comparative process. Comparative knowledge may be used to justify normative statements, but comparison itself neither proves the truth of a belief nor reveals one legal rule or doctrine to be superior to others". JANSEN, Nils. Comparative law and comparative knowledge. In: REIMAN, Mathias; ZIMMERMANN, Reinhard (Eds.). The Oxford handbook of comparative law. New York: Oxford University Press, 2006, p. 337.

${ }^{84}$ Tradução nossa do original: "la finalidad primordial de examinar cuáles de ellas pueden auxiliar a fortalecer un sistema constitucional específico". CARPIZO, Jorge. Derecho constitucional latinoamericano y comparado, cit., p. 950. Não difere também da posição de Blagojevic: "Il est
} 
Consonante percibe Ancel, que esa sería la primera función, desde la Antigüedad, cuando se pensaba en termos de comparación de instituciones ${ }^{85}$ - se miraba siempre en el legislador y en sus tareas. De fato, "las contribuciones de la investigación comparativa pueden constituir la orientación más útil y el freno más eficaz para fantasía, a veces demasiado desenfrenada, los legisladores nacionales". 86 No sin motivo, Pegoraro afirma que "antes de todo, los resultados de los estudios comparados son, mas do que útiles, indispensables en el ámbito de la elaboración legislativa. (...) Raramente, un proyecto de leí es redactado sin que previamente se tengan consultado las experiencias desarrolladas en otros ordenamientos". 87

El legislador puede, entonces, encontrar en los resultados de un trabajo de derecho comparado una herramienta para mejor direccionar la norma que pretende ver vigente en la sociedad, conforme el interés que defenda y los beneficios que busque. En el propio escenario de luta política, que son los Parlamentos, los contendores estan aptos a utilizar del derecho comparado como arma de combate y fuente para los argumentos políticos en una dada dirección u otra. En esa medida, pueden, por ejemplo, escondiendo los conocimientos que tienen sobre el derecho comparado,

certainement possible et justifié de procéder, dans les dites études, à une analyse critique ante des modalités, de la technique et de l'intégralité des solutions dans les droits respectifs que de l'application, et des conséquences de l'application, de ces solutions dans le pays envisagé. Or, dans de nombreux cas ces études vont jusqu'à donner une appréciation, ou au moins une analyse critique, de la valeur des solutions dans un droit doné. Cette appréciation peut être d'une double nature; ou bien sous l'aspect de l'intégralité (selon l'ampleur, la clarté, l'applicabilité etc) de la réglementation juridique de l'institution faisant l'objet de l'étude, c'est-à-dire du point de vue de la technique, de la politique et de la clinique juridiques, ou bien sous l'aspect de la valeur et des conséquences sociales résultant de la réglementation juridique de l'institution étudiée". BLAGOJEVIC, Borislav T. La méthode comparative juridique. In: ROTONDI, M. (Ed.). Buts et méthodes du droit comparé. Padova: CEDAM; New York: Oceana Publications, 1973. (Série Inchieste di diritto comparato), p. 35.

${ }^{85}$ Tradução nossa do original: "las aportaciones de la investigación comparativa pueden constituir la orientación más útil y el freno más eficaz para la fantasía, a veces demasiado desenfrenada, de los legisladores nacionales". ANCEL, Marc. Utilidade e métodos do direito comparado, cit., p. 18.

${ }^{86}$ DI RUFFIA, Polo Biscaretti. Introducción al derecho constitucional comparado. Las formas de estado y las formas de gobierno. Las constituciones modernas. Traducción de Héctor Fix Zamudio. México: Fondo de Cultura Económica, 1979, p. 15.

${ }^{87}$ Tradução nossa do original: "antes que nada, los resultados de los estudios comparados son, más que útiles, indispensables en el ámbito de la elaboración legislativa. (...) Raramente, un proyecto de ley se redacta sin que previamente se hayan consultado las experiencias desarrolladas en otros ordenamientos". PEGORARO, Lucio. El método en el derecho constitucional..., cit., p. 17. No mesmo sentido, ver ZWEIGERT, Konrad; KÖTZ, Hein. Introduction to comparative law, cit., p. 16; DAVID,

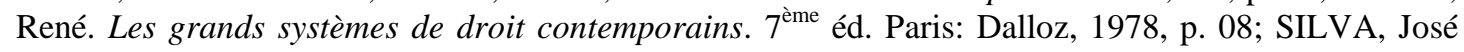
Afonso da. Um pouco de direito constitucional comparado, cit., p. 29. Ainda nessa linha, com uma visão institucional política, Tocqueville argumentava a favor do conhecimento de outras realidades nacionais, especificamente a estadunidense: "No solamente para satisfacer una curiosidad, por otra parte muy legítima, he examinado la América; quise encontrar en ella enseñanzas que pudiésemos aprovechar". TOCQUEVILLE, Alexis de. La democracia en America. Tradução de Luis R. Cuéllar. 2. ed. México: Fondo de Cultura Económica, 2002, p. 39. 
proponer redacciones y contenidos normativos en proyectos de leí o alteraciones constitucionales de modo a buscar efectos distintos de aquellos que deberían resultar del proyecto - eso porque conocen la experiencia de reglas similares en otros países. En resumen, tomar contacto con pesquisas comparativas fomenta las propias estrategias de combate político.

Esta tesis corresponde, en última instancia, a una apuesta institucional. SE buscan elementos y puntos de apoyo teórico-práctico para una reforma de la democracia brasileña. Esa perspectiva se abriga de un carácter conservador; por fin, como recuerda Saramago, reformar algo "no es más que cambiar lo suficiente para que todo se mantenga igual". ${ }^{88}$ A pesar de eso, creemos que existen cambios institucionales que pueden incentivar procesos políticos importantes. O sea, la ingeniera institucional trae efectos e influencia el modo como los atores políticos actúan en la disputa por el poder estatal, por eso es un aspecto que no puede ser ignorado. La elección de esa perspectiva exploratoria determina de modo particular como se dará el desarrollo del trabajo, o sea, el abordaje empezará obligatoriamente de las instituciones y de su funcionamiento en las respectivas realidades constitucionales, se afastando, al menos de inicio, de un debate interpretativo hermenéutico que parece ser típico del mundo de los constitucionalistas. ${ }^{89}$

De ese modo, la finalidad de este trabajo lleva en consideración aquello que, del punto de vista ideal, constituí los elementos positivos de los institutos de democracia directa, que es incentivar la participación, promover una cultura de manifestación de la ciudadanía en los temas de interés público, mejorar la transparencia y el control de la política, como también la posibilidad de dinamizar la acción de los partidos políticos. ${ }^{90}$ Es eso lo que buscaremos en la construcción de una propuesta lege ferenda. Obviamente, nos interesa también encontrar regulaciones

\footnotetext{
${ }^{88}$ SARAMAGO, José. Democracia e universidade. Belém: Editora da UFPA; Lisboa: Fundação José Saramago, 2013, p. 72.

${ }^{89}$ Bercovici faz a seguinte crítica quanto a esse ponto: “Ocorre, no Brasil pós-1988, algo paradoxal: os cientistas políticos e sociólogos buscam, cada vez mais, compreender o funcionamento das instituições e seu regime jurídico-constitucional. Já os constitucionalistas, por sua vez, refugiam-se nos debates sobre a aplicação das normas e da hermenêutica e interpretação constitucionais, tornando o judiciário praticamente o único setor estatal estudado e analisado por um direito público que se pretende democrático, mas não fala de democracia. O risco de uma teoria constitucional sem preocupações com o Estado é o do abandono pela política democrática e partidária, da esfera da constituição". BERCOVICI, Gilberto. Estado intervencionista e Constituição social no Brasil: o silêncio ensurdecedor de um diálogo entre ausentes. In: NETO, Cláudio Pereira de Souza; SARMENTO, Daniel; BINENBOJM, Gustavo (Coords.). Vinte anos da Constituição Federal de 1988. Rio de Janeiro: Lumen Juris, 2009, p. 734-735.

${ }^{90}$ LISSIDINI, Alicia. Democracia directa en latinoamérica..., cit., p. 11.
} 
normativas constitucionales que busquen reducir algunos riesgos típicos vinculados al uso de los mecanismos de democracia directa, como el aumento de la verticalidad de las decisiones (delegación) a partir de un Poder Ejecutivo fortalecido ${ }^{91}$ y la implementación de políticas que buscan eliminar o reducir derechos y garantías fundamentales de minorías sociales que tradicionalmente tienen sus derechos violados. Adoptamos aquí la visión de Vega, para quién la potencial utilización negativa y desvirtuante (disfuncional) de los institutos de participación directa debe ser remediada por una regulación jurídica adecuada. ${ }^{92}$

Conforme destacado, este trabajo busca elaborar una apuesta normativa de carácter lege ferenda con el intuito de mejorar el esqueleto constitucional brasileño. Se debe atentar para el fato de que tal perspectiva puede parecer, a primera vista, un paso a más de lo razonable, teniendo en vista aquello que se espera, en regla, de una pesquisa de cuño jurídico. La elección de una solución normativa para determinado problema no está colocada simplemente por la objetividad del resultado de la pesquisa; al revés, existe el análisis político valorativo del pesquisidor. Sabemos que elaborar y proponer leyes no equivale a pesquisarlas, como también la tarea del estudioso es científica, técnica, neutra y objetiva, al paso que el legislador, por ser agente político, toma su posición ideologico-programatico en busca de influenciar ó mismo asumir posiciones estatales. ${ }^{93} \mathrm{Si}$ las dos situaciones no pueden ser confundidas, significa que el producto de una pesquisa comparada, en tesis, debería salir de las manos del jurista como un producto prácticamente neutro, fruto de un encadenamiento intelectual que siguió los rigores de la ciencia. Frente a ese producto, el agente político, en ese caso el legislador, tendría que tomar su posición, indicando cual es el mejor camino a seguir. La discrecionalidad o arbitrariedad es atributo típico del político, y no del cientista.

Con efecto, al pesquisidor no competiría tomar posiciones políticas y, en ese sentido, Kennedy observa en el campo del derecho comparado un esfuerzo para se abstener de cualquier identificación con posiciones ideológicas o de interés social, ${ }^{94}$

\footnotetext{
${ }^{91}$ LISSIDINI, Alicia. Democracia directa en latinoamérica..., cit., p. 11.

92 VEGA, Pedro de. La reforma constitucional y la problematica del poder constituyente. Madrid: Tecnos, 2011, p. 127.

${ }^{93}$ WEBER, Max. Ciência e política: duas vocações. Tradução de Leonidas Hegenberg e Octany Silveira da Mota. São Paulo: Cultrix, 2011, p. 55.

${ }^{94}$ KENNEDY, David. The methods and the politics. In: LEGRAND, Pierre; MUNDAY, Roderick (Eds.). Comparative legal studies: traditions and transitions. Cambridge: Cambridge University Press,
} 
sintetizando esa conjetura del siguiente modo: "el derecho comparativo hoy es al respecto de conocer, y no hacer". ${ }^{95}$ Sacco busca no negar tal perspectiva, al decir que "la comparación es potencialmente imparcial y tiene el directo de serlo". " Existe, por tanto, una preocupación clara en mantener un status de respeto científico.

Elegir la mejor solución (delante de una realidad particular) envolvería un juzgamiento de valor, ${ }^{97}$ configurando un elemento subjetivo, que es al respecto de opciones de cada persona. Lo que sería la mejor solución segundo el juicio de una persona para otra, con valores e intereses distintos, podría representar la peor. Este tipo de procedimiento llevaría a la perdida de neutralidad y objetividad del trabajo científico-jurídico. Al constatar eso, no sorprende que Miranda elabore la siguiente asertiva:

\begin{abstract}
Bien entendido, no cabe al jurista qua tale - naturalmente suscitado la, entre distintas soluciones de problemas iguales, considerar unas mejores que otras - promover una política legislativa, mezclándose en terreno que no es más suyo. Pero no es menos cierto que no hay política legislativa segura sin el diagnóstico del estado del Derecho positivo, al cual contribuí, en medida no despreciable, lo que se sabe de los Derechos positivos extranjeros. Y mucho podría decirse, mutatis mutandis, sobre la política jurisprudencial. ${ }^{98}$
\end{abstract}

El discurso de la neutralidad es talvez uno de los más conocidos en el ámbito académico; todo lo que se pide, por ejemplo, a un profesor en clase es que este sea neutro al ministrar su disciplina y haga con que los estudiantes "piensen por sí". Obviamente, a los que demandan ese comportamiento de un docente, debería ser preguntado a lo que se refieren cuando hablan en "neutralidad".

En realidad, ningún pesquisidor o docente es neutro en su trabajo a punto de estar frente a su objeto de estudio como una persona vacía de ideología y valores adquiridos socialmente. ${ }^{99}$ Acá poco importa si eso se da de modo consciente o no. Es

2003, p. 346. Disponível em: <http://www.law.harvard.edu/faculty/dkennedy/publications/DKennedy TheMethodsandThePolitics.pdf $>$. Acesso em: 28 jul. 2016.

${ }^{95}$ Tradução nossa do original: "comparative law today is about knowing, not doing". KENNEDY, David. The methods and the politics, cit., p. 346.

${ }^{96}$ SACCO, Rodolfo. Introdução ao direito comparado. Tradução de Véra Jacob de Fradera. São Paulo: Revista dos Tribunais, 2001, p. 27.

97 WHYTOCK, Christopher. Legal origins, functionalism, and the future of comparative law. Bringham Young University Law Review, v. 2009, n. 6, p. 1.887, Feb., 2009.

98 MIRANDA, Jorge. Sobre o direito constitucional comparado, cit., p. 255.

${ }^{99}$ A demanda por uma docência completamente neutra (vazia) equivaleria a uma busca pela "ciência pura" da mesma maneira que se pode desejar encontrar uma arte pura ou arte pela arte. As análises de 
un requisito proprio de la pesquisa científica tener valores y visiones del mundo; de ese modo, Weber argumenta que "solamente las ideas de valor que dominan el investigador y una época pueden determinar el objeto del estudio y los límites de ese estudio". 100 Efectivamente, la determinación del objeto de pesquisa y de las cuestiones sobre la problemática dependen de forma preponderante de los elementos valorativos que sean preestablecidos en la cabeza de quien va realizar la busca investigativa. Sin ese presupuesto no hay pesquisa.

Hegel, en una parte excepcional de su Introducción a la filosofía de la historia universal, consigue captar esa visión al tratar del trabajo científico del historiador:

Por consiguiente, como primera condición, podríamos formular la de concebir fielmente el histórico; solo que en expresiones tan generales como fielmente y concebir reside a la ambigüedad. También el historiador corriente y mediano, que intenta y pretende conducir apenas a la manera del inventariarte, entregando solamente al que es dado, no es pasivo en su pensar; trae consigo sus categorías y mira por medio de ellas lo existente. El verdadero no reside en la superficie sensible; en todo lo que singularmente debe ser científico la razón no puede dormir, y hay que colocar la reflexión. Quien mira el mundo racionalmente lo divide también como racional; las dos cosas se encuentran en la determinación recíproca. ${ }^{101}$

Conviene, entonces, abandonar la idea de que es necesario un "miembro neutro" ó "vacío de convicciones" para realizar un estudio científico cualquiera. En realidad, ese discurso político que demanda neutralidad muchas veces cubre su inverso, porque puede un pesquisidor o profesor esconder sus opiniones y posiciones de modo de una exposición científica rigurosa y "neutra”. Es dentro de esa visión que Weber destaca que la forma más desleal de hacer prédica política utilizando del cargo

Benjamin quanto a isso são pertinentes: "Em outras palavras: o valor único da obra de arte 'autêntica' tem sempre um fundamento teológico, por mais remoto que seja: ele pode ser reconhecido, como ritual secularizado, mesmo nas formas mais profanas do culto do Belo. Essas formas profanas do culto do Belo, surgidas na Renascença e vigentes durante três séculos, deixaram manifesto esse fundamento quando sofreram seu primeiro abalo grave. Com efeito, quando o advento da primeira técnica de reprodução verdadeiramente revolucionária - a fotografia, contemporânea do início do socialismo levou a arte a pressentir a proximidade de um crise, que só se fez aprofundar-se nos cem anos seguintes, ela reagiu ao perido iminente com a doutrina da arte pela arte, que é no fundo uma teologia da arte. Dela resultou uma teologia negativa da arte, soba a forma de uma arte pura, que não rejeita apenas toda função social, mas também qualquer determinação objetiva." BENJAMIN, Walter. A obra de arte na era de sua reprodutibilidade técnica. In: BENJAMIN, Walter. Magia e técnica, arte e política: ensaios sobre literatura e história da cultura. Tradução de Sérgio Paulo Rouanet. São Paulo: Brasiliense, 1985, p. 171.

${ }^{100}$ WEBER, Max. A "objetividade" do conhecimento nas ciências sociais. In: COHN, Gabriel (Org.); FERNANDES, Florestan (Coord.). Weber: sociologia. Tradução de Amélia Cohn e Gabriel Cohn. São Paulo: Ática, 2008, p. 100.

${ }^{101}$ HEGEL, Georg Wilhelm Friedrich. A razão na história..., cit., p. 33-34. 
de profesor era camuflar esos objetivos políticos con el argumento de "dejar que los fatos hablen". ${ }^{102}$ En esa orden de ideas, Demo sentencia: "la posición de neutralidad o es maliciosa, de quien busca una estrategia de aceptación no contestada, o es ingenua, de quien no percibe el compromiso de la neutralidad". ${ }^{103}$

El rigor científico de una pesquisa en derecho comparado no es atingido de modo impertinente por la falta de neutralidad del pesquisidor; en ese punto, es necesario evitar el discurso de una separación absoluta entre sujeto y objeto en ciencias sociales. Con base en esa perspectiva y con influencia directa del pensamiento weberiano, Jansen, a pesar de salientar que los análisis de una pesquisa en derecho comparado no deben tener un carácter evaluativo, se concluye que:

Investigaciones comparativas son determinadas, por un lado, por la elección de los objetos comparados y, por otro, por la elección de la cuestión comparativa (tertium comparationis). Esas elecciones son influenciadas por los intereses de conocimiento y evaluaciones sobre lo que interesa o lo que se cree como normal. Ellas deberían ser claramente declaradas y podrían ser medidas tanto por los padrones no académicos (por ejemplo, legales) y académicos relacionados a la calidad del resultado de la pesquisa comparativa. ${ }^{104}$

Löwy amplia ese cuadro de interferencia subjetiva en la producción científica (social), afirmando que "los juicios de valor, las ideologías, las visiones sociales del mundo, las opciones morales etc., juegan un papel no solamente en la selección del objeto y en la formulación de la problemática, pero en el conjunto de la averiguación científica, en todo el proceso de producción del conocimiento". ${ }^{105}$ Ocurre, de esa forma, que mismo una pesquisa en derecho comparado que no llegue a conclusiones valorativas y no indique cualquier camino para una reforma legislativa con vistas a "mejorar" determinado ordenamiento nacional está impregnada de esa falta de "neutralidad". 106

102 WEBER, Max. Ciência e política: duas vocações, cit., p. 39.

${ }^{103}$ DEMO, Pedro. Introdução à metodologia da ciência. 2. ed. São Paulo: Atlas, 2013, p. 74.

${ }^{104}$ Tradução nossa do original: "comparative investigations are determined on the one hand by the choice of objects compared, and on the other by the choice of the comparative question (tertium comparationis). These choices are influenced by epistemic interests and evaluations about what matters on or what counts as normal. They should be openly stated and may be measured by both nonacademic (eg legal) values and academic standards relating to the quality of the result of comparative research". JANSEN, Nils. Comparative law and comparative knowledge, cit., p. 337.

${ }^{105}$ LÖWY, Michael. Ideologias e ciência social: elementos para uma análise marxista. São Paulo: Cortez, 2010, p. 59.

106 Não vamos entrar aqui em discussão mais detalhada sobre como, muitas vezes, a visão conservadora impregna a metodologia da comparação de direitos partindo de pressupostos políticos e 
$\mathrm{Si}$ al final de una pesquisa en derecho comparado existe una tomada de posición del pesquisidor en la dirección de cierta reforma del ordenamiento jurídico, su contribución para la política legislativa (no neutra) depende de aspectos vehiculados al contenido científico del análisis realizadas. En caso de un comparatista del derecho se arriesgue en esa "apuesta” política, el tendrá que "probar" que, a partir del contenido de la pesquisa, del método aplicado, de los dados alzados y de las interpretaciones hechas, la elaboración normativa propuesta como la "mejor" y más adecuada es la más pertinente delante de algunos objetivos políticos específicos.

Su test de rigor, la cientificidad y la "objetividad" se dan por la valoración de sus procedimientos, amplitud, capacidad de analisis, modo de abordaje, perspectiva adoptada, y, por fin, por el embate con otras posiciones políticas. El derecho comparado "en si" no existe, y sus métodos y resultados de pesquisa pueden ir en muchas direcciones. Al considerar que el derecho comparado puede ofrecer la "mejor opción" normativa, no se puede concluir que eso diga respecto a un mejor "universal", pero, si, que afecta determinados grupos sociales, beneficiando cierta visión del mundo en detrimento de otras - ahí esta su aspecto político.

Una propuesta legislativa elaborada a partir de una pesquisa comparativa debe mostrarse suficientemente fundamentada a punto de dar el debido soporte a la posición política defendida. Con efecto, es necesario tener coherencia "objetiva" en el procedimiento analítico de pesquisa a punto de llegar a la conclusión de que el efecto deseado con la propuesta legislativa elaborada (lege ferenda) tenga probabilidad (apuesta ${ }^{107}$ ) de ser efectivamente alcanzado en la realidad concreta. En el final de este estudio, buscamos construir algunos apuntamientos normativos constitucionales sobre los mecanismos de democracia directa, defendiendo que estos sean adoptados por el legislador brasileño en una futura reforma de la Ley Mayor de 1988 ó mismo durante un nuevo proceso constituyente. Esperamos que esa medida traga efectos benéficos dentro de cierta visión política.

ideológicos precisos que limitam completamente o horizonte da pesquisa. No fundo, trata-se de naturalizar o status quo, que aparece, assim, como ponto de vista "neutro" e "objetivo". Sobre esse aspecto, ver HILL, Jonathan. Comparative law: law reform and legal theory. Oxford Journal of Legal Studies, v. $9, \quad$ n. 1, p. 106-110, Spring 1989. Disponível em: <http://www.jstor.org/stable/pdf/764340.pdf?=1470168502182>. Acesso em: $1^{\circ}$ ago. 2016.

107 A ideia de "aposta" é utilizada por Matus, o qual estabelece que qualquer forma de planejamento da ação com vistas a um resultado desejado tem como pressuposto a existência de variáveis que o agente planejador não controla, de modo que se deve trabalhar sempre em termos de probabilidade. MATUS, Carlos. O plano como aposta. São Paulo em perspectiva, v. 4, n. 5, p. 28, out.-dez. 1991. Disponível em: <http://www.cgca.com.br/userfiles/file/O\%20Plano\%20Como\%20Aposta\%20por\%20Carlos\%20 Matus.pdf $>$. Acesso em: 20 nov. 2016. 
La tesis que defendemos en este trabajo es que la Constitución brasileña de 1988, cuando comparada as sus congéneres venezolana de 1999 y ecuatoriana de 2008, trae en su contenido un dibujo normativo conservador en términos de instrumentos de mecanismos de democracia directa, lo que significa decir que estos: (i) no son una vía capaz de traer bloqueos políticos (control democrático) para medidas de carácter antipopular; (ii) no constituyen potenciales salidas para amenizar crisis políticas y evitar violaciones al régimen democrático institucional; (iii) tiene grande potencial para que sean utilizados de modo a implementar políticas populistas ${ }^{108}$ tendientes a poner en riesgo derechos y garantías fundamentales; y (iv) tienen poca capacidad de traer incentivo a la construcción de una democracia de alta intensidad (participativa). En el analisis comparativo, verificaremos también que la Constitución brasileña de 1988 se aproxima de la realidad constitucional española de 1978 en términos formales y de experiencia, a pesar de tener algunas distinciones importantes.

Delante de esa construcción crítica que iremos proponer algunos caminos para seguir en una posible reforma del ordenamiento constitucional brasileño (considerando, incluso, perspectivas infra constitucionales), de modo a potencializar los efectos benéficos de esos instrumentos y neutralizar sus defectos en la actual regulación. Se reforzar que no presentamos una propuesta de reforma constitucional terminada y detallada, pero simplemente realizaremos apuntamientos en ese sentido a partir de la analisis comparativa.

Al defendernos la reforma de la Constitución de 1988, en busca de tener una mejor estructura normativa de los instrumentos de la democracia directa, no estamos hablando que esta debe ser la primera de las reformas o la más importante, pero

\footnotetext{
${ }^{108}$ Uma das expressões mais comuns de um populismo que atinge direitos e garantias fundamentais se dá no campo criminal (o que corresponde a um populismo de direita). Ao tecer considerações sobre a situação política italiana, Ferrajoli adverte que: "En el síndrome de la derecha italiana el enemigo tiene rostros diversos, geográficos, sociales, políticos o culturales: el Sur respecto del Norte, los inmigrantes clandestinos, los delincuentes callejeros, los comunistas, la oposición, la prensa libre, lo intelectuales, el sindicato (...). Itália está convirtiéndose en un país envenenado por el miedo, por el odio a los diferentes y por el desprecio de los débiles. Miedo y racismo, sospecha y desconfianza hacia los diversos, inseguridad y agresividad social han sido, en estos años, intensamente alimentados por la demagogia de la seguridad de las derechas, a la que las izquierdas han sido en gran medida subalternas. El miedo ha sido siempre un recurso del poder político: puede producirlo él mismo, como en los regímenes abiertamente autoritarios, o servirse de él, secundándolo o alimentándolo con objeto de obtener consenso y legitimación, con el las campañas populistas de apoyo a medidas penales tan duramente represivas como inútiles e ineficaces. (...) Es inútil decir que los principales blancos del populismo penal son los immigrantes, contra los que se han publicado leyes duramente represivas y discriminatorias". FERRAJOLI, Luigi. Poderes salvajes, cit., p. 68.
} 
apenas que ella se hace necesaria. No parece prudente ignorar los mecanismos de la democracia directa.

Definido el objeto, las finalidades y la tesis del estudio que sigue, conviene hacer algunos apuntamientos sobre las dimensiones del abordaje científico de la pesquisa. Para alcanzarnos los resultados críticos deseados, vamos considerar no solo como las reglas son previstas, pero también el modo como son aplicadas. En otros términos, la comparación textual de las normas constitucionales que instituyen los mecanismos de la democracia directa y sus respectivas reglamentaciones infra constitucionales no nos fornece todos los elementos pertinentes para una valoración cuanto a las "mejores soluciones" normativas adecuadas a la realidad brasileña. Es importante huir del puro formalismo jurídico, una vez que los mecanismos de la democracia directa no pueden ser analizados únicamente a partir de las reglas constitucionales que los reconocen. ${ }^{109}$ En ese sentido, debemos preguntar como funcionan concretamente los mecanismos que tienen el intuito de promover la democracia directa en países como España, Brasil, Venezuela y Ecuador.

Cuanto el analisis a ser realizado, más una dimensión es importante, cual sea, la de los contextos generales. Si los problemas enfrentados por los diversos paises no sean similares, o sea, tuvieran algunas particularidades relevantes que los diferencien, la busca a partir del método comparativo por una mejor solución normativa para esos problemas será muy difícil. El que tiene potencial de ser una muy buena solución dentro de un ordenamiento constitucional, talvez se muestre una elección inadecuada para otro: "una solución jurídica que efectivamente minimiza un problema en una sociedad puede no ser apropiada para otra si el problema siendo resuelto en aquella es distinta de aquel que necesita de una solución". 110

Realmente, cuanto a ese punto, se puede imaginar que los problemas son idénticos, o mejor, universales, por mientras en realidad no lo son, y eso tiene el potencial de comprometer el resultado de cualquier pesquisa que busque las mejores soluciones para situaciones concretas. Así, "si se piensa que los problemas son

\footnotetext{
${ }^{109}$ BARRIENTOS, Francisco Soto. El referédum en latinoamérica: un análisis desde el derecho comparado. Boletin Mexicano de Derecho Comparado, Universidad Nacional Autónoma de México, Ciudad de México, v. 46, n. 136, p. 318, enero-abr. 2013. Disponível em: <http://www.redalyc.org/articulo.oa?id=42725646009>. Acesso em: 12 abr. 2015.

${ }^{110}$ Tradução nossa do original: "a legal solution that effectively mitigates a problem in one society might not be appropriate for another society if the problem being solved in the former is different from the problem that needs to be solved in the latter". WHYTOCK, Christopher. Legal origins, functionalism, and the future of comparative law, cit, p. 1.886.
} 
universales, entonces, se debe pensar que en tipos de sociedad similares los medios jurídicos para responder esos problemas van a producir los mismos resultados". ${ }^{111} \mathrm{La}$ problemática acá es la tendencia de universalizar los problemas y las soluciones. ${ }^{112}$

No llevar en cuenta el contexto en el proceso de análisis comparativa, principalmente los elementos que componen el cuadro socioeconómico, puede redundar en una visión incompleta y destorcida de las realidades confrontadas, ${ }^{113}$ una vez que las particularidades contextuales tienen un efecto importante sobre las normas que serán aplicadas. "La misma regla jurídica puede producir distintos resultados en diferentes paises (y, talvez, resultados irrelevantes en algunos países) debido a estos factores contextuales". ${ }^{114}$ Con efecto, la finalidad objetivada con la aplicación de determinada norma termina por encontrar un resultado diverso $\mathrm{y}$, muchas veces, no deseado cuando implementada en realidades diversas. ${ }^{115}$ En síntesis, las reglas jurídicas no pueden ser completamente comprendidas si son aisladas de su contexto. $^{116}$

Dessarte, para hablar de los posibles efectos de la mejor solución normativa, debemos llevar en cuenta el contexto económico, político, social y cultural de cada realidad estatal estudiada: “... $\sin$ entender las interacciones potencialmente complexas entre las reglas jurídicas y los factores contextuales, es difícil estimar los efectos de causas de las reglas jurídicas con un nivel útil de seguridad". ${ }^{117}$ En

${ }^{111}$ Tradução nossa do original: "if one thinks that problems are universal, then one has to think also that in similar types of societies the legal ways to respond these problems will produce quite similar results". HUSA, Jaakko. About the methodology of comparative law - some comments concerning the Wonderland... Maastricht: Maastricht Faculty of Law Working Paper, 2007, p. 09.

${ }^{112}$ Nesse sentido, Zweigert assevera que "nous constatons que dans différents ordres juridiques les mêmes tâches son remplies de la même facón, et cela malgré des différences de structure dogmatique...." ${ }^{112}$ ZWEIGERT, Konrad. Des solutions identiques par des voies différentes - quelques observations en matière de droit comparé. Revue Internationale de Droit Comparé, v. 18, n. 1, p. 16, janv.-mars 1966.

${ }_{113}$ ACUÑA, Roger Merino. Comparative law from below. The construction of a critical project in comparative legal studies. Saarbrücken: Lampert, 2012, p. 17.

114 Tradução nossa do original: "The same legal rule may produce different results in different countries (and perhaps no significant results in some countries) due to such contextual factors". WHYTOCK, Christopher. Legal origins, functionalism, and the future of comparative law, cit., p. 1.898.

115 BRAND, Oliver. Conceptual comparisons: towards a coherent methodology of comparative legal studies. Brooklyn Journal of International Law, Brooklyn Law School, v. 32, n. 2, p. 415, 2007.

${ }^{116}$ PONTHOREAU, Marie-Claire. Le droit comparé en question(s): entre pragmatisme et outil épistemologique. Revue Internacionale de Droit Comparé, v. 57, n. 1, p. 14, 2005.

${ }^{117}$ Tradução nossa do original: “... without understanding the potentially complex interactions between legal rules and contextual factors, it is difficult to estimate the causal effects of legal rules with a useful degree of certainty". WHYTOCK, Christopher. Legal origins, functionalism, and the future of comparative law, cit., p. 1.899. Com a mesma perspectiva, vamos o que Jackson e Tushnet dizem: 
resumen, para realizar el analisis del derecho constitucional comparado, es necesario considerar la "evolución juridico-politica y la realidad del país", ${ }^{118}$ para evitar errores de analisis. ${ }^{119}$ Como refuerza Hirschl, "constituciones no se originan y tampoco operan en el vacuo. Su importancia no puede ser descrita o explicada con algún significado si independiente de fuerzas sociales, políticas e económicas, todas domesticas e internacionales, que las mueldan". ${ }^{120}$

Resulta evidente también que ninguna análisis en derecho comparado puede tomar todos los factores contextuales existentes tampoco "puede explicar todos los factores contextuales relevantes - eso sería un padrón irreal". ${ }^{121}$ Seria tarea igualmente imposible sumergir de modo pleno en un cultura extranjera buscando comprender completamente sus reglas jurídicas. ${ }^{122} \mathrm{El}$ pesquisidor, siempre que posible, debe cercarse de procedimientos que busquen alcanzar el máximo de los elementos contextuales que influencian la aplicación de la regla jurídica sometida a estudio. Es necesario buscar refletir sobre el movimiento real de la aplicación de una norma en determinada sociedad considerando su contexto. En un estudio de derecho comparado, no se encuentran problemas y posibles soluciones universales, pero, si, perspectivas jurídicas para situaciones particulares. Los argumentos traídos anteriormente dan sustentación para que ese proyecto investigativo busque caminos

"Here comparativism brings to the fore the need to see particular legal institutions and doctrines in the political, legal, economic, and social contexts in which they are found." JACKSON, Vicki C.; TUSHNET, Mark. Defining the field of comparative constitutional law. Praeger Publishers: Westport, Connectcut, 2002, p. 12.

118 Tradução nossa do original: “evolución jurídico-política y la realidad del país”. CARPIZO, Jorge. Derecho constitucional latinoamericano y comparado, cit., p. 950.

119 Parece ser essa a perspectiva do alerta de Ancel: "Existe, é certo, uma verdade manifesta, mas que talvez se tenha perdido de vista; e nós não devemos esquecer os erros ou as aproximações prematuras que foram feitas em estudos que se desejavam como de direito comparado, vale dizer, horizontais, sem estudo vertical preliminar suficiente". ANCEL, Marc. Utilidade e métodos do direito comparado, cit., p. 109. Com uma compreensão mais específica, Cruz afirma: "A final error that comparatist has to guard against is not to overlook 'extra-legal' factors, which may be informal customs and practices, which operate outside strict law, or various non-legal phenomena, which ultimately influence the state of the law. One of the benefits of the effective utilisation of the comparative law methodology is to deepen and widen one's knowledge of the social and economic milieu within a legal system and legal rules operate". CRUZ, Peter de. Comparative law in a changing world, cit., p. 230.

120 Tradução nossa do original: "constitutions neighter originate nor operate in a vacuum. Their important cannot be meaningfully described or explained independent of the social, political, and economic forces, both domestic and international, that shape them". HIRSCHL, Ran. Comparative matters: the renaissance of comparative constitutional law. New York: Oxford University Press, 2014, p. 152.

${ }^{121}$ Tradução nossa do original: "no analysis can account for all relevant contextual factors - that would be an unrealistic standard". WHYTOCK, Christopher. Legal origins, functionalism, and the future of comparative law, cit., p. 1.903.

122 BRAND, Oliver. Conceptual comparisons..., cit., p. 414. 
capaces de ultrapasar el campo del análisis estrictamente jurídico, sin, perder el foco jurídico-constitucional, en la medida en que solo la lógica jurídica no es capaz de explicar los fenómenos del derecho ${ }^{123}$ - solo si se quiere que exista una comprensión puramente formalista. Por eso, es necesario llevar a serio el alerta de MirkineGuetzévitch, "El desconocimiento de las reglas jurídicas ciertamente es bien peligroso, pero no menos peligrosos son los abusos y los excesos del derecho". ${ }^{24}$ Como también puntúa Di Ruffia "las exigencias específicas de la investigación comparativa en el ámbito del derecho constitucional imponen, además de eso, la utilización de las contribuciones de varias ciencias no jurídicas que se refieren, igualmente, a los ordenamientos estatales". ${ }^{125}$ En las palabras de Jackson y Tushnet, "la función del Derecho constitucional y del Derecho constitucional comparado no puede ocurrir en aislamiento intelectual de los trabajos de otras disciplinas de la ciencia política, de la sociología, de la antropología cultural, de las ciencias cognitivas o de las ciencias económicas". ${ }^{126}$

Así, es pertinente notar que la ciencia política será fundamental para el desarrollo de la pesquisa propuesta, una vez que en ese campo investigativo existe una relevante gama de análisis sobre los mecanismos de la democracia directa y ponderaciones sobre sus potenciales efectos.

Elaboradas esas consideraciones introductorias, conviene rápidamente apuntar la estructura general del estudio que sigue. La primera parte del trabajo es compuesta

\footnotetext{
${ }^{123}$ Nesse sentido, Mirkine-Guetzévitch afirma que “une loi n'est jamais une raison écrite. Elle est un compromis dans la lutte des groupes, des partis, des individus. Historiquement, la loi est toujours une transaction. C'est porquoi la logique juridique seule n'est pas capable d'expliquer le droit'. MIRKINEGUETZÉVITCH, Boris. Les méthodes d'étude du droit constitutionnel comparé. Revue Internationale de Droit Comparé, v. 1, n. 4, p. 401, oct.-déc. 1949.

${ }^{124}$ Tradução nossa do original: "La méconnaissance des règles juridiques est certes bien dangereuse; non moins dangereux cependant sont les abus et les excès du droit". MIRKINE-GUETZÉVITCH, Boris. Les méthodes d'étude du droit constitutionnel comparé, cit., p. 398.

${ }^{125}$ Tradução nossa do original: "las exigencias específicas de la investigación comparativa en el ámbito del derecho constitucional imponen, además, la utilización de las aportaciones de varias ciencias no jurídicas que se referien, igualmente, a los ordenamientos estatales". DI RUFFIA, Polo Biscaretti. Introducción al derecho constitucional comparado, cit., p. 23. No mesmo sentido, Pegoraro assevera: "En resumen, el Derecho Comparado y, dentro de este ámbito, el Derecho Público Comparado posee autonomia respecto de otras ciencias. No obstante lo cual, no puede dejar de utilizar al mismo tiempo o por separado la Historia Jurídica, la Historia de las Doctrinas Políticas, la Ciencia Política, la Filosofia, la Sociologia del Derecho y otras ramas del saber". PEGORARO, Lucio. El método en el derecho constitucional..., cit., p. 23. Ver também MIRKINE-GUETZÉVITCH, Boris. Les méthodes d'étude du droit constitutionnel comparé, cit., p. 397.

${ }^{126}$ Tradução nossa do original: "the work of constitutional law and comparative constitutional law cannot carry forward in intellectual isolation from the work of other disciplines of political science, sociology, cultural antropology, the cognitive sciences, or economics". JACKSON, Vicki C.; TUSHNET, Mark. Defining the field of comparative constitutional law. Westport, CT: Praeger, 2002, p. 12.
} 
de tres capítulos que buscan demarcar las discusiones prácticas y teóricas a respecto de los mecanismos de democracia directa. Se trata de una aproximación inicial con el tema, algo esencial para el abordaje comparativo. Así, en el Capítulo 1 tratamos el modo como los mecanismos de la democracia directa encuentran su lugar dentro del sistema representativo. En el 2o Capítulo exponemos pormenorizadamente algunos conceptos vehiculados al tema de la democracia y de la participación directa, abordando las modalidades tradicionales de los mecanismos de la democracia directa y sus características principales. En el Capítulo 3, por su vez, traemos algunas controversias que dieron oportunidad a un gran debate sobre los riesgos traídos por los institutos de democracia directa.

La segunda parte de la pesquisa se dedica al examen individualizado del régimen constitucional ecuatoriano de 2008 (Capítulo 4), venezolano de 1999 (Capítulo 5), español de 1978 (Capítulo 6) y brasileño de 1988 (Capítulo 7). Lanzamos un mirar atento sobre las regulaciones constitucionales sobre los mecanismos de la democracia directa, llevando en cuenta la estructura de cada Constitución, las reglas infra constitucionales y el modo como esos institutos fueron concebidos y aplicados, además de versar sobre las críticas que recibieron. Se destaca que todas esas cuestiones son examinadas a luz de la tradición constitucional de cada país y de su contexto socio-histórico.

Por fin, en el Capítulo 8 elaboramos analisis comparativas pontuales entre los cuatro paises estudiados, buscando dar fundamento para algunas propuestas generales de reforma a la actual regulación Constitucional brasileña de 1988 a respecto a los mecanismos de democracia directa. 


\section{CONCLUSÃO}

Chegamos ao final de nosso itinerário de pesquisa. Em face de uma tese sempre há de se perguntar sobre a confirmação das perspectivas hipotéticas iniciais. Como ponto de partida, afirmamos que a Constituição brasileira de 1988, quando comparada às suas congêneres venezuelana de 1999 e equatoriana de 2008, traz em seu conteúdo um desenho normativo conservador em termos de instrumentos de mecanismos de democracia direta, o que significou dizer que estes: (i) não eram uma via capaz de gerar bloqueios políticos (controle democrático) para medidas de caráter antipopular; (ii) não constituíam potenciais saídas para amenizar crises políticas e evitar violações ao regime democrático institucional; (iii) tinham grande potencial de serem utilizados de modo a implementar políticas populistas tendentes a pôr em risco direitos e garantias fundamentais; e (iv) tinham pouca capacidade de gerar incentivo à construção de uma democracia de alta intensidade (participativa). Propusemos ainda que a análise comparativa revelaria que a Constituição brasileira de 1988 se aproxima da realidade constitucional espanhola de 1978 em termos formais e de experiência, embora haja algumas distinções importantes.

Traçado esse horizonte, a partir da abordagem teórico-jurídica dos mecanismos de democracia direta, exploramos individualmente cada realidade constitucional. A nossa perspectiva, contudo, foi além do puro formalismo jurídico, de modo que as análises recaíram também sobre os processos históricos de cada país, os elementos contextuais e as experiências concretas em relação aos institutos de democracia direta. Com esse material minimamente observado e trabalhado, partimos para as elaborações comparativas.

O Capítulo 8, embora não traga todos os aspectos e elementos explorados nos capítulos precedentes, em que tratamos do regime constitucional da democracia direta de cada país, corresponde, em última instância, ao desdobramento final da pesquisa por nele estar contido o ponto de ebulição da tarefa científica proposta, qual seja: o procedimento de aproximação e distanciamento entre as ordenações constitucionais e o indicativo de distinções e semelhanças em matéria de normas reguladoras dos instrumentos de democracia direta. Por óbvio, nesse capítulo encontramos os aspectos conclusivos mais importantes que dão substrato às propostas normativas dirigidas à uma futura reforma do ordenamento constitucional brasileiro. 
Cabe aqui, então, destacar alguns pontos. Nos quatro ambientes constitucionais estudados, identificamos a presença de mecanismos de democracia direta compartilhando o espaço com as instituições de democracia representativa. Formalmente, contudo, parece claro que as previsões dos institutos de democracia direta presentes na Constituição de 1988 são quantitativamente inferiores quando lançamos o nosso olhar sobre o Texto Constitucional venezuelano de 1999, equatoriano de 2008 e espanhol de 1978. Basta lembrar, nesse sentido, que no Brasil desconhecemos o procedimento popular de revogação de mandato, instituto albergado nas atuais Cartas Políticas da Venezuela e do Equador, bem como não encontramos qualquer possibilidade de uma revisão constitucional total ou parcial em que o povo participe diretamente por meio de referendo aprovando a respectiva reforma.

Já no campo da experiência, o contexto político brasileiro se mostrou austero na prática da democracia direta. Raros foram os referendos e plebiscitos implementados, havendo alguns impulsos no caso das iniciativas legislativas populares, que, no entanto, apontaram para um cenário de utilização que podemos chamar de populista conservador, atrelados, em regra, à discussão de enrijecimento de penas criminais ou limitações moralistas no campo eleitoral. No Equador e na Venezuela, por sua vez, a tendência de utilização é um pouco maior, visto que há uma preponderância de impulso de cima para baixo, basicamente por interesse e ação dos ocupantes dos cargos presidenciais. Bem verdade, quanto ao Equador, a tradição de participação popular direta é maior se consideramos como ponto de partida para a análise a Constituição de 1979, que finalizou a transição democrática nesse país. No que diz respeito à Espanha, a perene movimentação dos institutos de participação direta assemelha-se muito à realidade brasileira, em que o Poder Legislativo tem predomínio no campo da iniciativa. O cuidado que tomamos foi não avaliar precipitadamente essa pouca implementação dos instrumentos de democracia direta como algo negativo em si.

Não ignoramos que alguém poderia concluir que a regulação dos mecanismos de participação direta na Constituição de 1988 é a mais pertinente politicamente, sobretudo em face de um contexto de provável utilização populista conservadora ou plebiscitária desses institutos. Assim, tanto a ampliação de tais formas participativas quanto o seu aperfeiçoamento normativo seriam medidas indesejáveis; o mais seguro seria manter tudo como está. Trata-se de um posicionamento condizente com uma defesa das instituições representativas e, ao mesmo tempo, de caráter antipopular. $\mathrm{O}$ 
problema dessa perspectiva é não dar a atenção devida ao fato de que as conjunturas políticas particulares muitas vezes demandam a aplicação de mecanismos de democracia direta.

Por isso, a não previsão desses institutos ou a regulação insatisfatória de seus conteúdos em determinada ordenação constitucional pode acarretar impasses políticos relevantes. Em situações extremas, esse contexto normativo tem a probabilidade de levar à implementação desses mesmos institutos de forma ad hoc, sem qualquer respeito às determinações jurídicas vigentes. As formas de destituição de Presidentes da República ocorridas nos últimos 20 anos na América Latina dão sustentação a essas análises: impeachments, declarações de abandono de cargo e alegações de insanidade mental foram aplicados diversas vezes em total desconformidade com os Textos Constitucionais, em violação direta à cláusula democrática. Nesses casos, havia uma aproximação evidente entre as destituições presidenciais e o instituto de revogação de mandato, típico mecanismo de democracia direta.

Foi perante esses pressupostos que, ao final da pesquisa, elaboramos indicativos gerais para que sirvam como suporte de uma futura proposta de alteração da atual regulação jurídico-constitucional brasileira. O centro de nossas preocupações foi intensificar os aspectos democráticos da atuação popular, mitigando os potenciais usos indesejáveis dos institutos de democracia direta. Dentre os apontamentos normativos apresentados como proposta, ressaltamos particularmente a necessidade de empoderamento da cidadania no que diz respeito à competência para dar impulso à utilização dos mecanismos de democracia direta. Assim, partimos de uma crítica em relação ao caráter restritivo existente atualmente na Constituição brasileira de 1988, que dá preponderância ao Legislativo quanto ao poder de iniciativa para a celebração de referendos e plebiscitos.

Com efeito, às cidadãs e aos cidadãos brasileiros deveria ser conferida a competência para propor a implementação de consultas populares (referendos e plebiscitos), estas podendo versar inclusive sobre a aprovação de reformas constitucionais, a convocação de Assembleias Constituintes revisoras, a adoção de tratados internacionais e a revogação de mandato eletivo - sempre respeitando, em todas essas hipóteses, os direitos e as garantias fundamentais, bem como o princípio democrático. Na construção de nossas propostas, procuramos delinear também as porcentagens de assinaturas mínimas que deveriam ser requeridas para que uma 
iniciativa popular fosse de cumprimento obrigatório por parte dos poderes constituídos.

De maneira geral, esse foi o caminho percorrido em nosso estudo. Ao final, como destacado desde o início, chegamos a uma aposta de caráter institucional, cujo objetivo é aperfeiçoar e potencializar os aspectos democráticos do sistema políticoconstitucional brasileiro. Em se tratando de uma aposta, evidencia-se a ideia de probabilidade de resultados, ou seja, acreditamos que a direção geral das alterações constitucionais que propusemos em face de toda a pesquisa comparativa tem maior potencial de atingir os objetivos traçados.

Além disso, é importante dizer que em nenhum momento advogamos uma fé cega nos mecanismos democracia direta ou na opinião popular; pelo contrário, construímos o nosso pensamento a partir de certas intenções políticas, considerando os elementos objetivos das situações concretas vivenciadas em nossa realidade. Os institutos de democracia direta não têm o condão de resolver os problemas nacionais, mas podem ter um impacto relevante no resultado dos conflitos políticos entre indivíduos, classes e grupos sociais. 


\section{CONCLUSIONES}

Llegamos al final de nuestro itinerario de investigación. A la luz de una tesis siempre hay que preguntarse sobre la confirmación de las perspectivas hipotéticas iniciales. Como punto de partida, afirmamos que la constitución brasileña de 1988, cuando comparada a sus congéneres venezolana de 1999 y ecuatoriana de 2008, trae en su contenido un dibujo normativo conservador en términos de instrumentos de mecanismos de democracia directa, lo que significó decir que esos: (i) no eran una vía capaz de generar bloqueos políticos (control democrático) para medidas de carácter antipopular; (ii) no constituían potenciales salidas para amenizar crisis políticas y evitar violaciones al régimen democrático institucional;(iii) tenían gran potencial de ser utilizado de modo a implementar políticas populistas tendentes a poner en riesgo derechos y garantías fundamentales; y (iv) había poca capacidad de generar incentivo a la construcción de una democracia de alta intensidad (participativa). Planteamos aún que el análisis comparativo revelaría que la constitución brasileña de 1988 se acerca de la realidad constitucional española de 1978 en términos formales y de experiencia, sin embargo, haya algunas distinciones importantes.

Trazado ese horizonte, a partir de un abordaje teórico-jurídico de los mecanismos de democracia directa, exploramos individualmente cada realidad constitucional. Nuestra perspectiva, sin embargo, fue además de puro formalismo jurídico, de modo que los análisis que recayeron también sobre los procesos históricos de cada país, los elementos contextuales y las experiencias concretas en relación a los institutos de democracia directa. Con ese material mínimamente observado y trabajado, partimos para las elaboraciones comparativas.

El Capítulo 8, aunque no traiga todos los aspectos y elementos explorados en los capítulos precedentes, en que tratamos del régimen constitucional de la democracia directa de cada país, corresponde, en última instancia, al desdoblamiento final de la investigación por en él estar contenido el punto de ebullición de la tarea científica propuesta, cual sea: el procedimiento de acercamiento y alejamiento entre las ordenaciones constitucionales y el indicativo de distinciones y similitudes en materia de las normas regladores de los instrumentos de democracia directa. Por obvio, en ese capítulo encontramos los aspectos conclusivos más importantes que dan 
substrato a las propuestas normativas dirigidas a una futura reforma de ordenamiento constitucional brasileño.

Cabe subrayar, entonces, destacar algunos puntos. En los cuatro ambientes constitucional estudiados, identificamos la presencia de los mecanismos de la democracia directa compartiendo el espacio con las instituciones de la democracia representativa. Formalmente, sin embargo, parece claro que las previsiones de los institutos de democracia directa presentes en la constitución de 1988 son cuantitativamente inferiores cuando echamos un vistazo en el Texto Constitucional venezolano de 1999, ecuatoriano de 2008 y español de 1978. Basta recordar, en ese sentido, que en Brasil desconocemos el procedimiento popular de revocación de mandato, instituto albergado en las actuales Cartas Políticas de Venezuela y Ecuador, así como no encontramos cualquier posibilidad de una revisión constitucional total o parcial en que el pueblo participe directamente por medio de referendo aprobando la respectiva reforma.

Ya en el campo de la experiencia, el contexto político brasileño se mostró austero en la práctica de la democracia directa. Raros fueron los referendos y plebiscitos implementados, habiendo algunos impulsos en el caso de las iniciativas legislativas populares, que, sin embargo, apuntaron para un escenario de utilización que podemos llamar de populista conservador, encadenados, en regla, a la discusión de robustecimiento de penas criminales moralistas en el campo electoral. En Ecuador y en Venezuela, por su vez, la tendencia de utilización es un poco mayor, pues hay una preponderancia de impulso de arriba abajo, básicamente por interés y acción de los ocupantes de los cargos presenciales. Bien verdad, cuanto a Ecuador, la tradición de participación popular directa es mayor se consideramos como punto de partida para el análisis de la Constitución de 1979, que finalizó la transición democrática en ese país. En lo que dice respecto a España, el perene movimiento de los institutos de participación directa se asemeja mucho a la realidad brasileña, en que el Poder Legislativo tiene predominio en el campo de la iniciativa. El cuidado que tomamos fue no evaluar precipitadamente esa poca implementación de los instrumentos de democracia directa como algo negativo en si.

No ignoramos que alguien podría concluir que la regulación de los mecanismos de participación directa en la Constitución de 1988 es la más pertinente políticamente, sobre todo a raíz de un contexto de probable utilización populista conservadora o plebiscitaria de esos institutos. Así, tanto la ampliación de tales 
formas participativas cuanto su perfeccionamiento normativo serian medidas indeseables; lo más seguro sería mantener todo como está. Se trata de un posicionamiento condecente con una defensa de las instituciones representativas y, al mismo tiempo, de carácter antipopular. El problema de esa perspectiva es no dar la atención debida al hecho de que las coyunturas políticas particulares muchas veces demandan la aplicación de mecanismos de la democracia directa.

Por eso, la no previsión de esos institutos o la regulación insatisfactoria de sus contenidos en determinada ordenación constitucional puede conllevar impases políticos relevantes. En situaciones extremas, ese contexto normativo tiene la probabilidad de llevar a la implementación de esos mismos institutos de forma ad hoc, sin cualquier respecto a las determinaciones jurídicas vigentes. Las formas de destitución de Presidentes de la República ocurridas en los últimos 20 años en Latinoamérica san sustentación a esos análisis: impeachments, declaraciones de abandono de cargo y alegaciones de insania mental fueron aplicados diversas veces en total desconformidad con los Textos Constitucionales, en violación directa a la cláusula democrática. En esos casos, había un acercamiento evidente entre las destituciones presidenciales y el instituto de revocación de mandato, típico mecanismo de democracia directa.

Fue delante de esos presupuestos que, al final de la investigación, elaboramos indicativos generales para que sirvan como soporte de una futura propuesta de alteración de la actual regulación jurídico-constitucional brasileña. El centro de nuestras preocupaciones fue intensificar los aspectos democráticos de la actuación popular, mitigando por potenciales usos indeseables de los institutos de democracia directa. Entre los apuntamientos normativos presentados como propuesta, resaltamos particularmente la necesidad de empoderamiento de la ciudadanía en lo que dice respecto a la competencia para dar impulso a la utilización de los mecanismos de democracia directa. Así, partimos de una crítica con relación al carácter restrictivo existente actualmente en la constitución brasileña de 1988, que da preponderancia al Legislativo cuanto al poder de la iniciativa para la celebración de referendos y plebiscitos.

Con efecto, a las ciudadanas y ciudadanos brasileños debería ser conferida a la competencia para proponer la implementación de consultas populares (referendos y plebiscitos), estas pudiendo versar incluso sobre la aprobación de reformas constitucionales, la convocación de Asambleas Constituyentes revisoras, la adopción 
de tratados internacionales y la revocación de mandato electivo- siempre respetando, en todas esas hipótesis, los derechos y garantías fundamentales, así como el principio democrático. En la construcción de nuestras propuestas, buscamos delinear también los porcentajes de firmas mínimas que deberían ser requeridas para que una iniciativa popular fuera de cumplimiento obligatorio por parte de los poderes constituidos.

De manera general, ese fue el camino recorrido en nuestro estudio. Al final, como destacado desde el inicio, llegamos a una apuesta de carácter institucional, cuyo objetivo es perfeccionar y potencializar los aspectos democráticos del sistema político-constitucional brasileño. Tratándose de una apuesta, se evidencia la idea de probabilidad de resultados, o sea, creemos que la dirección general de las alteraciones constitucionales que propusimos a la luz de toda la investigación comparativa tiene mayor potencial de atingir los objetivos trazados.

Además, es importante decir que en ningún momento defendemos una fe ciega en los mecanismos de democracia directa o en la opinión popular; al contrario, construimos nuestro pensamiento a partir de ciertas intenciones políticas, considerando los elementos objetivos de las situaciones concretas vivenciadas en nuestra realidad. Los institutos de democracia directa no tienen la varita mágica de resolver los problemas nacionales, pero pueden tener un impacto relevante en el resultado de los conflictos políticos entre individuos, clases y grupos sociales. 


\section{REFERÊNCIAS}

ACHCAR, Gilbert. A guerra espanhola 1936. In: LÖWY, Michael (Org.). Revoluções. Tradução de Yuri Martins Fontes. São Paulo: Boitempo, 2009.

ACKERMAN, Bruce. Anatomy of a Constitutional Coup. London Review of Books, v. 23, n. 3, p. 3-68, Feb. 2001. Disponível em: <http://www.lrb.co.uk/v23/n03/bruceackerman/anatomy-of-a-constitutional-coup>. Acesso em: 20 out. 2016.

ACKERMAN, Bruce. The new separation of powers. Harvard Law Review, v. 113, n. 3, p. 633-729, Jan. 2000. Disponível em: <https://www.jstor.org/stable/pdf/1342286. pdf? =1471656792307>. Acesso em: 22 ago. 2016.

ACOSTA, Alberto. Ecuador: ecos de la rebelión de los forajidos. Nueva Sociedad, n. 198, p. 42-54, jul.-agosto 2005. Disponível em: <http://nuso.org/articulo/ecuadorecos-de-la-rebelion-de-los-forajidos/>. Acesso em: 24 jul. 2016.

ACOSTA, Alberto. Ecuador: el bucaranismo en el poder. Nueva Sociedad, n. 146, nov.-dic., p. 6-16, 1996. Disponível em: <http://nuso.org/media/articles/downloads/ 2543 1.pdf>. Acesso em: 24 jul. 2016.

ACOSTA, Alberto. Ecuador: el coronel mató pronto a la esperanza. Ecuador Debate, Quito, n. 61, p. 2-23, abr. 2004.

ACOSTA, Alberto. La Asamblea Nacional Constituyente. In: HARNECKER, Marta. Ecuador: una nueva izquierda en busca de la vida en plenitud. Buenos Aires: El Viejo Topo, 2011.

ACUÑA, Roger Merino. Comparative law from below. The construction of a critical project in comparative legal studies. Saarbrücken: Lampert, 2012.

AGÊNCIA BRASIL. Plebiscito revela que maioria dos eleitores é contra a Alca. Brasília, 17 set. $2002 . \quad$ Disponível em: $<$ http://memoria.ebc.com.br/agenciabrasil/node/ 587756>. Acesso em: 24 set. 2016.

AGESTA, Luis Sánchez. Curso de derecho constitucional comparado. Madrid: Universidad de Madrid, 1980.

AGUILAR, Juan Fernando Lopez. De la constitución "irreformable" a la reforma constitucional “exprès”. Teoría y Realidad Constitucional, n. 29, p. 199-218, 2012. 
Disponível em: <http://revistas.uned.es/index.php/TRC/article/view/6987/6685>. Acesso em: 13 out. 2016.

ALTMAN, David. Democracia directa en el continente americano: ¿autolegitimación gubernamental o censura ciudadana? Política y gobierno, v. XII, n. 2, p. 203-232, 2005.

ALTMAN, David. Direct democracy worldwide. New York: Cambridge University Press, 2011.

ALZAGA, Oscar. Comentário sistemático a la Constitución española de 1978. Madrid: Ediciones del Foro, 1978.

ANCEL, Marc. Utilidade e métodos do direito comparado. Tradução de Sérgio José Porto. Porto Alegre: Sergio Antonio Fabris Editor, 1980.

ANDERSON, Perry. Crisis in Brasil. London Review of Books, v. 38, n. 8, p. 15-22, 2016. Disponível em: <http://www.lrb.co.uk/v38/n08/perry-anderson/crisis-inbrazil>. Acesso em: 15 nov. 2016.

ANDERSON, Perry. Linhagens do Estado absolutista. Tradução de João Roberto Martins Filho. São Paulo: Brasiliense, 2004.

ANTUNES, Ricardo. As rebeliões de junho de 2013. Observatório Social de América Latina, CLACSO, año XIV, n. 34, p. 37-49, nov. 2013.

ARAGON, Manuel. La iniciativa legislativa. Revista Española de Derecho Constitucional, n. 16, año 6, p. 287-312, enero-abr. 1986. Disponível em: $<$ http://www.cepc.gob.es/publicaciones/revistas/revistaselectronicas?IDR=6\&IDN=31 $\underline{8 \& I D A=24788>}$. Acesso em: 21 set. 2016.

ARAUJO, Joan Oliver. El referéndum en el sistema constitucional español. Revista de Derecho Político, n. 29, p. 115-182, 1989. Disponível em: <http://revistas.uned.es/ index.php/derechopolitico/article/view/8421>. Acesso em: 05 jun. 2016.

ARAUJO, Joan Oliver. Encuesta sobre el referéndum. UNED, Teoría y Realidad Constitucional, n. 30, p. 11-56, 2012. Disponível em: <http://revistas.uned.es/ index.php/TRC/issue/view/514>. Acesso em: 18 jul. 2016. 
ARBLASTER, Anthony. A democracia. Tradução de M. F. Gonçalves de Azevedo. Lisboa: Editorial Estampa, 1988.

ARCINIEGA, Daniel Granda. El hiperpresidencialismo en el Ecuador. Quito: Universidad Central del Ecuador Facultad de Comunicación Social (FACSO), 2012.

ARISTÓTELES. A política. Tradução de Roberto Leal Ferreira. São Paulo: Martins Fontes, 2006.

AVRIL, Pierre; GICQUEL, Jean. Droit parlementaire. Paris: Montchrestien, 2004.

BALLOUSSIER, Anna Virginia. Maconha, cassinos e sacolas serão temas de voto nos EUA em novembro. Folha de S.Paulo, São Paulo, 14 ago. 2016. Folha Mundo. Disponível em: <http://m.folha.uol.com.br/mundo/2016/08/1802769-maconhacassinos-e-sacolas-serao-temas-de-voto-nos-eua-em-

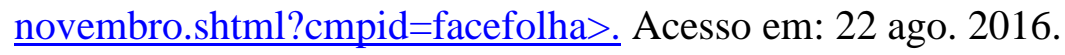

BALKIN, Jack M. Bush v. Gore and boundary between law and politics. The Yale Law Journal, v. 110, n. 8, p. 1.407-1.458, June 2001. Disponível em: < http://www.yale.edu/ lawweb/jbalkin/articles/essayonbushvgore.pdf>. Acesso em: 07 set. 2016.

BARANGER, Denis. Le droit constitutionnel. 5. ed. Paris: PUF, 2010.

BARBER, Benjamin R. Strong democracy. Participation politics for a new age. Berkeley: University of California Press, 2003.

BARCZAK, Monica. Representation by consultation? The rise of direct democracy in Latin America. Latin American Politics and Society, Wiley and Center for Latin American Studies at the University of Miami, v. 43, n. 3, p. 37-59, Autumn 2001.

BARRIENTOS, Francisco Soto. El referédum en latinoamérica: un análisis desde el derecho comparado. Boletin Mexicano de Derecho Comparado, Universidad Nacional Autónoma de México, Ciudad de México, v. 46, n. 136, p. 317-346, enero-abr. 2013. Disponível em: <http://www.redalyc.org/articulo.oa?id=42725646009>. Acesso em: 12 abr. 2015. 
BARROS, Pedro Silva. Chávez e petróleo: uma análise da nova política econômica venezuelana. Cadernos PROLAM/USP, v. 2, ano 5, p. 209-237, 2006. Disponível em: $\langle$ http://www.plataformademocratica.org/Publicacoes/11707.pdf $>$. Acesso em: 05 abr. 2016.

BASES COMICIALES DEL CONSTITUYENTE. Disponível em: $<$ http://pdba.georgetown.edu/Elecdata/Venezuela/bases.html $>$. Acesso em: 12 abr. 2016.

BATISTA JR., Paulo Nogueira. A Alca e o Brasil. Estudos Avançados, v. 17, n. 48, p. 267-293, 2003. Disponível em: 〈http://www.revistas.usp.br/eav/article/view/9936>. Acesso em: 23 set. 2016.

BAUMAN, Zygmunt. Tempos líquidos. Tradução de Carlos Alberto Medeiros. Rio de Janeiro: Zahar, 2007.

BBC BRASIL. O estranho dia em que o FMI criticou o neoliberalismo, 30 jun. 2016. Disponível em: <http://www.bbc.com/portuguese/geral-36668582>. Acesso em: 10 out. 2016.

BEÇAK, Rubens. Democracia: hegemonia e aperfeiçoamento. São Paulo: Saraiva, 2014.

BELL JR., Derrick A. The referendum: democracy's barrier to racial equality. Washington Law Review, v. 54, n. 1, p. 01-29, 1978. Disponível em: $<$ http://heinonline.org/HOL/LandingPage?handle=hein.journals/washlr54\&div=9\&id =\&page $=>$. Acesso em: 28 out. 2016.

BENEVIDES, Maria Victoria de Mesquita. A cidadania ativa. Referendo, plebiscito e iniciativa popular. São Paulo: Ática, 2003.

BENEVIDES, Maria Victoria. O plebiscito de 1993 à luz do precedente de 1963. Lua Nova: Revista de Cultura e Política, São Paulo, n. 28-29, abr. 1993.

BENJAMIN, Walter. A obra de arte na era de sua reprodutibilidade técnica. In: BENJAMIN, Walter. Magia e técnica, arte e política: ensaios sobre literatura e história da cultura. Tradução de Sérgio Paulo Rouanet. São Paulo: Brasiliense, 1985. 
BERCOVICI, Gilberto. Estado intervencionista e Constituição social no Brasil: o silêncio ensurdecedor de um diálogo entre ausentes. In: NETO, Cláudio Pereira de Souza; SARMENTO, Daniel; BINENBOJM, Gustavo (Coords.). Vinte anos da Constituição Federal de 1988. Rio de Janeiro: Lumen Juris, 2009.

BERCOVICI, Gilberto. Plebiscito e referendo sobre matéria administrativa. In: MARQUES NETO, Floriano; MENEZES, Fernanda Dias; NOHARA, Irene Patricía; MARRARA, Thiago (Orgs.). Direito e administração pública: estudos em homenagem a Maria Sylvia Zanella Di Pietro. São Paulo: Atlas, 2013.

BETTO, Frei. Plebiscito da Alca é defesa da soberania do Brasil. São Paulo, 02 set. 2002. Disponível em: <http://cartamaior.com.br/?/Coluna/Plebiscito-da-Alca-edefesa-da-soberania-do-Brasil/22102>. Acesso em: 24 set. 2016.

BLAGOJEVIC, Borislav T. La méthode comparative juridique. In: ROTONDI, M. (Ed.). Buts et méthodes du droit comparé. Padova: CEDAM; New York: Oceana Publications, 1973. (Série Inchieste di diritto comparato).

BOBBIO, Norberto. Direito e estado no pensamento de Emanuel Kant. Tradução de Alfredo Fait. 3. ed. São Paulo: Mandarim, 2000.

BOBBIO, Norberto. Liberalismo e democracia. Tradução de Marco Aurélio Nogueira. São Paulo: Brasiliense, 2007.

BOBBIO, Norberto. O filósofo e a política. Antologia. Tradução de César Benjamin. Rio de Janeiro: Contraponto, 2003.

BOBBIO, Norberto. Qual democracia? Tradução de Marcelo Perine. 2. ed. São Paulo: Loyola, 2013.

BOBBIO, Norberto. Teoria geral da política. A filosofia política e as lições dos clássicos. Tradução de Daniela Beccaccia Versiani. Rio de Janeiro: Elsevier, 2000.

BOITO JUNIOR, Armando. Estado, política e classes sociais: ensaios teóricos e históricos. São Paulo: Editora da Unesp, 2007. 
BOLlE, Monica de. O novo regime fiscal. Estadão, São Paulo, 10 out. 2016. Disponível em: 〈http://economia.estadao.com.br/blogs/monica-de-bolle/o-novoregime-fiscal/>. Acesso em: 11 out. 2016.

BONAVIDES, Paulo. Curso de direito constitucional. 23. ed. São Paulo: Malheiros, 2008.

BONAVIDES, Paulo; ANDRADE, Paes de. História constitucional do Brasil. Brasília: Paz e Terra, 1989.

BORJA, Rodrigo. Derecho político y constitucional. México: Fondo de Cultura Económica, 1992.

BOURDIEU, Pierre. O mistério do mistério. Das vontades particulares à "vontade geral”. In: CANÊDO, Letícia Bicalho (Org.). O sufrágio universal e a invenção democrática. São Paulo: Estação Liberdade, 2005.

BOWLER, Shaun; GLAZER, Amihai. Hybrid democracy and its consequences. In: BOWLER, Shaun; GLAZER, Amihai (Eds). Direct democracy's impact on american political institutions. New York: Palgrave Macmillan, 2008.

BRAGA, Ruy. Sob a sombra do precariado. In: Cidades rebeldes: Passe Livre e as manifestações que tomaram as ruas do Brasil. São Paulo: Boitempo/Carta Maior, 2013.

BRAND, Oliver. Conceptual comparisons: towards a coherent methodology of comparative legal studies. Brooklyn Journal of International Law, Brooklyn Law School, v. 32, n. 2, p. 405-466, 2007.

BRESSER-PEREIRA, Luiz Carlos. A construção política do Brasil. Sociedade, economia e Estado desde a Independência. 2. ed. São Paulo: Editora 34, 2015.

BREUER, Anita. The use of government-initiated referendum in Latin America: towards a theory of referendum causes. Revista de Ciência Política, Pontificia Universidad de Chile, Santiago, v. 29, n. 1, p. 23-55, 2009. Disponível em: <http://www.redalyc.org/pdf/324/32414666002.pdf>. Acesso em: 10 dez. 2014.

BREWER-CARÍAS, Allan R. El secuestro de la Sala Electoral por la Sala 
Constitucional del Tribunal Supremo de Justicia. In: BREWER-CARÍAS, A.; PEÑA SOLÍS, J.; CHAVERO GAZDIK, R.; DUQUE CORREDOR, R.; ANTELA, R. La guerra de las Salas del TSJ frente al referéndum revocatorio. Caracas: Aequitas, 2004.

BREWER-CARÍAS, Allan R. El secuestro del poder electoral y la confiscación del derecho a la participación política mediante el referendo revocatorio presidencial: Venezuela, 2000-2004. Boletín Mexicano de Derecho Comparado, n. 112, año XXXVIII, p. 11-73, enero-abr. 2005.

BREWER-CARÍAS, Allan R. Golpe de Estado y proceso constituyente en Venezuela. Ciudad de México: Universidad Nacional Autónoma de México, 2001.

BREWER-CARÍAS, Allan R. La Constitución de 1999. 2. ed. Caracas: Editorial Jurídica Venezolana/Editorial Arte, 2000.

BREWER-CARÍAS, Allan R. La reforma constitucional en Venezuela de 2007 y su rechazo por el poder constituyente originario. Revista Peruana de Derecho Público, Lima, ano 8, n. 15, p. 13-53, jul.-dic. 2007. Disponível em: <http://www.garciabelaunde.com/Biblioteca/REVISTA_P15.pdf>. Acesso em: 27 set. 2016.

BREWER-CARÍAS, Allan R. ¿Reforma constitucional o mutación constitucional? La experiencia venezolana. Ponencia para el IV Congreso Colombiano de Derecho Procesal Constitucional y IV Congreso Internacional Proceso y Constitución "Dialéctica y diálogo jurisprudencial: presente y futuro". Centro Colombiano de Derecho Procesal Constitucional, Asociación de Derecho Procesal Constitucional, Bogotá, 18-20 de marzo de 2014, p. 28. Disponível em: <http://allanbrewer.com/Content/449725d9-f1cb-474b-8ab2-

41efb849fea8/Content/II,\%204,\%20639.\%20REFORMA\%20CONSTITUCIONAL\% 20Y\%20\%20FRAUDE\%20A\%20LA\%20CONSTITUCIÓN\%20Monterrey\%202009. doc).pdf>. Acesso em: 06 jun. 2016.

BUADES, Josep M. A guerra civil espanhola: o palco que serviu de ensaio para a Segunda Guerra Mundial. São Paulo: Contexto, 2013.

BUCCI, Eugênio. A forma bruta dos protestos: das manifestações de junho de 2013 à queda de Dilma Rousseff em 2016. São Paulo: Companhia das Letras, 2016. 
BUCHANAN, James M. Direct democracy, classical liberalism and constitutional strategy. Kyklos, v. 54, fasc. 2-3, p. 235- 242, 2001. Disponível em: $\langle$ http://onlinelibrary.wiley.com/doi/10.1111/1467-6435.00151/epdf $>$. Acesso em: 17 nov. 2014.

BUDGE, Ian. The new challenge of direct democracy. Cambridge: Polity Press, 1996.

BURKE, Edmund. Discurso aos eleitores de Bristol. Tradução de Cid Knipell Moreira. In: WEFFORT, Francisco C. (Org.). Os clássicos da política 2. São Paulo: Ática, 1995.

CAGGIANO, Monica Herman Salem. Democracia x constitucionalismo: um navio à deriva. Cadernos de Pós-Graduação em Direito: estudos e documentos de trabalho. Faculdade de Direito da Universidade de São Paulo, São Paulo, n. 1, p. 05-25, 2011.

CAGGIANO, Monica Herman Salem. Direito parlamentar e direito eleitoral. São Paulo: Manole, 2004.

CAGGIANO, Monica Herman Salem. Eleições 2002: o financiamento das campanhas eleitorais e seu controle. Enquadramento jurídico. Revista de Direito Mackenzie, São Paulo, ano 1, n. 1, jan./jun.2000, p. 89.

CAGGIANO, Monica Herman Salem. O cenário eleitoral e sua anatomia. Sistemas eleitorais e reforma política. Revista de Direito Brasileira, v. 2. n. 2, p. 399-423, 2012. Disponível em: <http://www.rdb.org.br/ojs/index.php/rdb/article/download/86/85>. Acesso em: 03 out. 2016.

CAGGIANO, Monica Herman Salem. O cidadão-eleitor, jogador com veto no processo eleitoral democrático: aspectos polêmicos e peculiaridades do cenário brasileiro. Eleições gerais/2010. In: INSTITUTO VICTOR NUNES LEAL (Org.). A contemporaneidade do pensamento de Victor Nunes Leal. São Paulo: Saraiva, 2013.

CAGGIANO, Monica Herman Salem. Oposição na política: proposta para uma rearquitetura da democracia. São Paulo: Angelotti, 1995. 
CANOTILHO, José Joaquim Gomes. "Brancosos" e interconstitucionalidade: itinerários dos discursos sobre a historicidade constitucional. $2^{\mathrm{a}}$ ed. Coimbra: Almedina, 2012.

CARDOSO, Fernando Henrique; FALETTO, Enzo. Dependência e desenvolvimento na América Latina: ensaio de interpretação sociológica. 7. ed. Rio de Janeiro: LTC, 1970.

CARDOSO, Rodrigo Mendes. A iniciativa popular legislativa da Assembleia Nacional Constituinte ao regime da Constituição de 1988: um balanço. 2010. Dissertação (Mestrado em Direito) - Pontifícia Universidade Católica do Rio de Janeiro, Rio de Janeiro, 2010, p. 111-112. Disponível em: 〈http://www.maxwell.vrac.puc-rio.br/17613/17613_6.PDF>. Acesso em: 03 jan. 2015

CARPIZO, Jorge. Derecho constitucional latinoamericano y comparado. Boletín Mexicano de Derecho Comparado, Universidad Nacional Autónoma de México, v. XXXVIII, n. 114, p. 949-989, sept.-dic. 2005.

CARTILHA PLEBISCITO CONSTITUINTE, 2. ed. Disponível em: <http://www.plebiscitoconstituinte.org.br/sites/default/files/material/AF_Cartilha\%20 Plebiscito\%202\% \%20Edição_WEB.pdf>. Acesso em: 22 set. 2016.

CARVALHO, Katia de. Síntese do rito processual seguido no impeachment do presidente Fernando Collor de Mello. Nota Técnica. Câmara dos Deputados. Disponível em: $\quad<\underline{\text { http://www2.camara.leg.br/documentos-e- }}$ pesquisa/publicacoes/estnottec/areas-da-conle/tema6/2015_26571_sintese-ritoimpeachment-collor_katia-de-carvalho>. Acesso em: 19 out. 2016.

CARVALHO, José Murilo de. Cidadania no Brasil: o longo caminho. 9. ed. Rio de Janeiro: Civilização Brasileira, 2007.

CASTRO, José Luis Cascajo. Encuesta sobre el referéndum. UNED, Teoría y Realidad Constitucional, n. 30, p. 11-56, 2012. Disponível em: <http://revistas.uned.es/ index.php/TRC/issue/view/514>. Acesso em: 18 jun. 2016. 
CEPEDA, Juan Paz y Miño. Ecuador: democracia con tensiones, sociedad con desatenciones. In: ANSALDI, Waldo (Dir.). La democracia en América Latina, un barco a la deriva. México: Fondo de Cultura Económica, 2006.

CEPEDA, Juan Paz y Miño. Ecuador: una democracia inestable. Historia Actual Online, n. 11, p. 89-99, otoño 2006. Disponível em: <http://historiaactual.org/Publicaciones/index.php/haol/article/viewArticle/170>. Acesso em: 10 ago. 2016.

CHAGNOLlAUD, Dominique. Introduction à la politique. Paris: Éditions du Seuil, 1993.

CHAUÍ, Marilena. Manifestações ideológicas do autoritarismo brasileiro. São Paulo: Autêntica/Perseu Abramo, 2013. v. 2.

CHEMERINSKY, Erwin. Challenging direct democracy. Michigan State Law Review, v. 293-306, p. 296-297, 2007. Disponível em: $<$ http://scholarship.law.duke.edu/cgi/

viewcontent.cgi? article $=2480 \&$ context $=$ faculty_scholarship $>$. Acesso em: 17 jan. 2015.

CHEVALIER, François. América Latina: de la independencia a nuestros días. México: Fondo de Cultura Económica, 1999.

CLARK, Sherman J. A populiste critique of direct democracy. Harvard Law Review, v. 112, 1999. Disponível em: 〈http://heinonline.org>. Acesso em: 10 jan. 2015.

COELHO, João Gilberto Lucas. Processo constituinte, audiências públicas e o nascimento de uma nova ordem. In: BACKES, Ana Luiza; AZEVEDO, Débora Bithiah de; ARAÚJO, José Cordeiro de. (Orgs.). Audiências públicas na Assembleia Nacional Constituinte: a sociedade na tribuna. Brasília: Câmara dos Deputados, Edições Câmara, 2009.

COLL, Ferran Requejo. Las democracias: democracia antigua, democracia liberal y Estado de bienestar. Barcelona: Ariel, 1994. 
COLLADO, Juan de Dios Izquierdo. El referéndum de 1947: antecedente del referéndum de la Ley de Reforma Política. Revista de Estudios Albacetenses, n. 14, p. 179-204, 1984. Disponível em: 〈https://dialnet.unirioja.es/ejemplar/120767〉. Acesso em: 10 jul. 2016.

COMAS, José. Los uruguayos rechazan el plan de privatizaciones de las empresas públicas. El País, Montevideo, 14 dic. 1992. Economía. Disponível em: <http://elpais.com/diario/1992/12/14/economia/724287607_850215.html〉. Acesso em: 25 ago. 2016.

COMBELLAS, Ricardo. Derecho constitucional: una introducción al estudio de la Constitución de la República Bolivariana de Venezuela. Caracas: McGraw-Hill Interamericana de Venezuela, 2000.

COMPARATO, Fábio Konder. O direito e o avesso. Estudos Avançados, São Paulo, IEA, v. 23, n. 67, p. 17, set.-dez. 2009.

COMUNICADO IPEA - Instituto de Pesquisa Econômica Aplicada n. 125. Divisões estaduais: aspectos relevantes de pesquisa e a experiência do plebiscito no Pará, 2011. Disponível em: <http://repositorio.ipea.gov.br/bitstream/11058/4459/1/ Comunicados_n125_Divisões.pdf $>$. Acesso em: 02 jan. 2016.

CONAGHAN, Catherine M. Correa's plebiscitary presidency. Journal of Democracy, v. $19, \quad$ n. 2, p. 46-60, Apr. 2008. Disponível em: <https://muse.jhu.edu/article/235508>. Acesso em: 29 ago. 2016.

CONSEJO NACIONAL ELECTORAL (CNE). Disponível em: <http://www.cne.gob.ve>. Acesso em: 12 abr. 2016.

CONTRERAS, Manuel. La reforma de la Constitución. In: RAMIREZ, Manuel (Dir.). Estudios sobre la Constitución Española de 1978. Zaragoza: Libros Pórtico, 1979.

COOTER, Robert D.; GILBERT, Michael D. A theory of direct democracy and the single subject rule. Columbia Law Review, v. 110, n. 3, p. 687-730, Apr. 2010.

COPPEDGE, Michael. Explaining democratic deterioration in Venezuela through nested inference. In: HAGOPIAN, Frances; MAINWARING, Scott P. (Eds.). The third wave of democratization in Latin America: advances and setbacks. New York: Cambridge University Press, 2008. 
COPPEDGE, Michael. Venezuela: soberanía popular versus democracia liberal. In: DOMÍNGUEZ, Jorge L.; SHIFTER, Michael (Eds.). Construcción de gobernabilidad democrática en América Latina. Bogotá: Fondo de Cultura Económica, 2005.

CORAO, Carlos Ayala. El referendo revocatorio. Una herramienta ciudadana de la democracia. Caracas: Los Libros de El Nacional, 2004.

CORDOVA, Polibio. Los resultados de la consulta electoral. Una comparación con eventos similares. In: MENA, Fernando Carrión (Dir.). Los resultados de la consulta popular en el Ecuador. Quito: FLACSO, 1995. Disponível em: <http://www.flacsoandes.edu.ec/libros/digital/47002.pdf >. Acesso em: 20 nov. 2015.

CORRALES, Javier; PENFOLD-BECERRA, Michael. Venezuela: crowding out the opposition. Journal of Democracy, v. 18, n. 2, p. 99-113, Apr. 2007. Disponível em: <https://muse.jhu.edu/article/214433>. Acesso em: 05 ago. 2016.

CORREIO CIDADANIA. Plebiscito confirma: a vida acima da dívida. Disponível em: <http://www.correiocidadania.com.br/antigo/ed211/politica.htm>. Acesso em: 22 set. 2016.

CRESPO, Santiago Ortiz. Participación ciudadana: la Constitución de 1998 y el nuevo proyecto constitucional. Iconos - Revista de Ciencias Sociales, Quito, n. 32, p. 13-17, sept. 2008.

CRONIN, E. Thomas. Direct democracy. The politics of initiative, referendum, and recall. Harvard University Press, 1999.

CRUZ, Peter de. Comparative law in a changing world. $3^{\text {rd }}$ ed. Edition. London: Routledge-Cavendish, 2007.

CUNHA, Sérgio Sérvulo da. Fundamentos de direito constitucional: constituição, tipologia constitucional, fisiologia constitucional. São Paulo: Saraiva, 2004.

DAHL, Robert. ¿Es democrática la Constitución de los Estados Unidos? Tradução de Pablo Gianera. México: Fondo de Cultura Económica, 2003.

DAHMS, Hellmuth Günther. A guerra civil espanhola. 1936-1939. Tradução de Daniel Brilhante de Brito. Rio de Janeiro: Editorial Bruguera, 1968. 
DALLARI, Dalmo de Abreu. Constituição e constituinte. 4. ed. São Paulo: Saraiva, 2010.

DALMAU, Rubén Martínez. El proyecto de Constitución de Ecuador, ejemplo del nuevo constitucionalismo latinoamericano. IUS - Revista del Instituto de Ciencias Jurídicas de Puebla, Puebla, n. 23, p. 264-274, 2009. Disponível em: <http://www.redalyc.org/pdf/2932/293222963011.pdf>. Acesso em: 05 nov. 2015.

DAVID, René. Les grands systèmes de droit contemporains. $7^{\text {̀̀me }}$ éd. Paris: Dalloz, 1978.

DEMO, Pedro. Introdução à metodologia da ciência. 2. ed. São Paulo: Atlas, 2013.

DI RUFFIA, Polo Biscaretti. Introducción al derecho constitucional comparado. Las formas de estado y las formas de gobierno. Las constituciones modernas. Traducción de Héctor Fix Zamudio. México: Fondo de Cultura Económica, 1979.

DIAS, Roberto. Atual Congresso brasileiro deveria ser dissolvido, diz sociólogo espanhol (Entrevista). Folha de S.Paulo, São Paulo, 02 jul. 2007. Folha Poder. Disponível em: <http://www1.folha.uol.com.br/poder/2013/07/1304810-atualcongresso-brasileiro-deveria-ser-dissolvido-diz-sociologo-espanhol.shtml>. Acesso em: 22 dez. 2016.

DIAZ, Elias. Estado de direito e sociedade democrática: o que é o estado de direito. Tradução de António Guimarães. Lisboa: Iniciativas Editoriais, 1972.

DPHIL, Enrique Ayala Mora. Rasgos de la reciente experiencia constitucional del Ecuador. In: STORINI, Claudia; GARCÍA, José Francisco Alenza (Coords). Materiales sobre neoconstitucionalismo y nuevo constitucionalismo latinoamericano. Navarra: Thomson Reuters, 2012.

DUVERGER, Maurice. Metodos de las ciencias sociales. Tradução de Alfonso Sureda. Barcelona: Ariel, 1980.

ECUADOR. Constitución Política (1967). Disponível em: <http://www.constitutionnet.org/files/1967.pdf $>$. Acesso em: 23 nov. 2015. 
ECUADOR. Constitución Política (1978). Disponível em: < $\underline{\text { http://www.cortenacional. }}$ gob.ec/cnj/images/pdf/constituciones/43\%201978\%20Texto\%20Original.pdf >. Acesso em: 20 out. 2015.

ECUADOR. Constitución Política (1998). Disponível em: <http://pdba.georgetown.edu/

Constitutions/Ecuador/ecuador98.html\#mozTocId362880>. Acesso em: $1^{\circ}$ dez. 2015.

ECUADOR. Informe del Presidente del Tribunal Supremo Electoral, 1997. Disponível em: <https://repositories.lib.utexas.edu/bitstream/handle/2152/17555/libro_2. pdf?sequence>. Acesso em: 20 nov. 2015.

EULE, Julian N. Judicial review of direct democracy. The Yale Law Journal, v. 99, n. 7, p. 1.503-1.590, May 1990. Disponível em: <http://www.jstor.org/stable/pdf/ 796652.pdf>. Acesso em: 10 jan. 2015.

FABRE-GOYARD, Simone. O que é democracia. A genealogia filosófica de uma grande aventura humana. Tradução de Claudia Berliner. São Paulo: Martins Fontes, 2003.

FERNÁNDEZ, Albert Noguera. Participación, función electoral y función de control y transparencia social. In: SANTAMARÍA, Ramiro Ávila; JIMÉNEZ, Agustín Grijalva; DALMAU, Rubén Martínez (Coords.). Desafíos constitucionales. La Constitución ecuatoriana del 2008 en perspectiva. Quito: Tribunal Constitucional del Ecuador, 2008.

FERRAJOLI, Luigi. Poderes salvajes. La crisis de la democracia constitucional. Tradução de Andrés Ibánez. Madrid: Editorial Trotta, 2011.

FERREIRA FILHO, Manoel Gonçalves. Do processo legislativo. São Paulo: Saraiva, 2002.

FINLEY, Moses I. Democracia antiga e moderna. Tradução de Waldéa Barcellos. Rio de Janeiro: Graal, 1988. 
FLEINER-GESTER, Thomas. Teoria geral do Estado. Tradução de Marlene Holzhausen. São Paulo: Martins Fontes, 2006.

FLEURY, Sonia. Iniciativa popular. In: AVRITZER, Leonardo; ANASTASIA, Fátima (Orgs.). Reforma política no Brasil. Belo Horizonte: Editora da UFMG, 2006.

FOLHA DE S.PAULO. FMI diz que não renega neoliberalismo e políticas de austeridade. São Paulo, 02 jun. 2016. Folha Economia. Disponível em: < http://www1.folha.uol.com.br/mercado/2016/06/1777507-fmi-diz-que-nao-reneganeoliberalismo-e-politicas-de-austeridade.shtml>. Acesso em: 10 out. 2016.

FONSERET, Roque Moreno; CALERO, Francisco Sevillano. La legitimación del franquismo: los plebiscitos de 1947 y 1966 en la provincia de Alicante. Anales de la Universidad de Alicante. Historia contemporánea, n. 8-9, p. 121-138, 1991-1992. Disponível em: 〈https://dialnet.unirioja.es/servlet/articulo?codigo $=258801>$. Acesso em: 15 jul. 2016.

FRANÇA, William. Aprovada nova lei que redefine crime hediondo. Folha de S.Paulo, São Paulo, 09 set. 1994. Folha Cotidiano. Disponível em: <http://www1.folha.uol. com.br/fsp/1994/9/09/cotidiano/25.html>. Acesso em: 05 de out. 2016.

FUENTES-ROHWER, Luís. The emptiness of majority rule. Michigan Journal of Race and Law, v. 1, p. 195-260. Disponível em: $<$ http://heinonline.org/HOL/Page?handle= hein.journals/mjrl1\&div $=11 \&$ start_page $=195 \&$ collection=journals\&set_as_cursor $=6$ \&men $\_$tab $=$srchresults $>$. Acesso em: 24 ago. 2016.

FULIARO, Ana Paula. Democracia na América Latina: enfoque especial: alternância no poder. 2016. Tese (Doutorado em Direito) - Faculdade de Direito da Universidade de São Paulo, São Paulo, 2016.

FUNG, Archon; WRIGHT, Erik Olin. Deepening democracy: innovations in empowered participatory governance. Politics \& Society, Sage Publications, v. 29, n. 1, p. 5-41, Mar. 2001. 
FURTADO, Celso. Ensaios sobre a Venezuela: subdesenvolvimento com abundância de divisas. Rio de Janeiro: Contraponto, 2008.

GALLEGOS, Franklin Ramírez. El despliegue de la democracia directa en el Ecuador pos constitucional. In: LISSIDINI, Alicia; WELP, Yanina; ZOVATTO, Daniel (Orgs.). Democracias in movimiento: mecanismos de democracia directa y participative en America Latina. Stockholm: International Institute for Democracy and Electoral Assistance (International IDEA), 2014.

GARCÍA, Eloy. Encuesta sobre el referéndum. UNED, Teoría y Realidad Constitucional, n. 30, p. 11-56, 2012. Disponível em: <http://revistas.uned.es/ index.php/TRC/issue/view/514>. Acesso em: 18 jul. 2016.

GARCÍA, Eloy; CASTRO, José Luis Cascajo; ARAUJO, Joan Oliver; MURO, Ignacio Torres. Encuesta sobre el referéndum. UNED. Teoría y Realidad Constitucional, n. 30, 2012, p. 31. Disponível em: <http://revistas.uned.es/index.php/TRC/issue/view/514>. Acesso em: 18 jul. 2016.

GARCÍA, Michel Rowland. La crisis de representatividad del régimen político ecuatoriano: una aproximácion institucional. In: JACKISCH, Carlota (Comp.). Representación política y democracia. Buenos Aires: Konrad Adenauer Stiftung Ciedla, 1998.

GARETTO, Daniel Zovatto. Las instituciones de la democracia directa a nivel nacional en América Latina: un balance comparado: 1978-2007. Revista de Derecho Electoral, n. 4, Tribunal Supremo de Elecciones, San José, p. 1-51, 2. sem. 2007.

GARGARELLA, Roberto. Cambiar la letra, cambiar el mundo. Equador Debate, Quito, n. 75, p. 93-66, dic. 2008.

GARGARELLA, Roberto. ¿Democracia deliberativa y judicialización de los derechos sociales? Perfiles Latinoamericanos, v. 13, n. 28, p. 09-51, 2006. Disponível em: <http://perfilesla.flacso.edu.mx/index.php/perfilesla/article/view/213>. Acesso em: 27 out. 2016.

GARGARELLA, Roberto. El constitucionalismo latinoamericano y la "sala de máquinas" de la Constitución (1980-2010). Gaceta Constitucional, n. 48, p. 289-305, 
2011. Disponível em: <http://www.gacetaconstitucional.com.pe/sumario-cons/docsum/GC\%2048\%20Roberto\%20GARGARELLA.pdf>. Acesso em: 17 out. 2016.

GARGARELLA, Roberto. Latin American constitutionalism, 1810-2010: the engine room of the constitution. Oxford: Oxford University Press, 2013.

GARGARELLA, Roberto. Pensando sobre la reforma constitucional en América Latina. In: GARAVITO, César Rodríguez (Coord.). El derecho en América Latina: un mapa para el pensamiento jurídico del siglo XXI. Buenos Aires: Siglo Veintiuno Editores, 2011.

GARGARELLA, Roberto. Theories of democracy, the judiciary and social rights. In: GARGARELlA, Roberto; DOMINGO, Pilar; ROUX, Theunis (Eds.). Courts and social transformation in new democracies. An institutional voice for the poor? Hampshire: Ashgate, 2006.

GAUDIN, Jean-Pierre. La démocratie participative. 2. ed. Paris: Armand Colin: 2013.

GIL, Antonio Hernandez. Facetas de dos procesos constituyentes. Revista de Estudios Políticos (Nueva Época), n. 31-32, p. 11-24, enero-abr. 1983. Disponível em: $<$ http://www.cepc.gob.es/publicaciones/revistas/revistaselectronicas?IDR=3\&IDN=19 1>. Acesso em: 21 jul. 2016.

GILABERT, Francisco Martí. La primera república 1873-1874. Madrid: Ediciones Rialp, 2007.

GOHN, Maria da Glória. Manifestações de junho de 2013 no Brasil e praças dos indignados no mundo. Petrópolis: Vozes, 2014.

GOMES, Sandra. O impacto das regras de organização do processo legislativo no comportamento dos parlamentares: um estudo de caso da Assembleia Constituinte (1987-1988). Dados, Rio de Janeiro, v. 49, 2006.

GONZÁLEZ, José Luis. El referéndum en el sistema español de participación política. Valencia: Universidad Politécnica de Valencia, 2005.

GOW, James Iain. Les effets pervers d'une bonne idée: la démocratie directe en Californie. Politique et Sociétés, v. 17, n. 1-2, p. 239-271, 1998. Disponível em: <http://id.erudit.org/iderudit/040107ar>. Acesso em: 10 dez. 2014. 
GRAU, Eros Roberto. A constituinte e a Constituição que queremos. São Paulo: Revista dos Tribunais, 1985.

GUNTHER, Richard. El proceso constituyente español. Revista de Estudos Políticos (Nueva Época), n. 49, p. 39, enero-feb. 1986. Disponível em: <http://www.cepc.gob.es/ publicaciones/revistas/revistaselectronicas?IDR=3\&IDN=207\&IDA=16296 Acesso em: 19 jun. 2016.

HABERMAS, Jürgen. Sobre a constituição da Europa. Tradução de Denilson Luis Werle, Luiz Repa e Rúrion Melo. São Paulo: Editora da Unesp, 2012.

HAMILTON, Alexander; MADISON, James; JAY, John. O federalista. Tradução de Heitor de Almeida Herrera. Brasília: Editora da UnB, 1984.

HARTLYN, Jonathan; VALENZUELA, Arturo. A democracia na América Latina após 1930. In: BETHELL, Leslie (Org.). História da América Latina. Tradução de Antonio de Pádua Danesi. São Paulo: Editora da Universidade de São Paulo, 2009. v. VII - A América Latina após 1930: Estado e política.

HEGEL, Georg Wilhelm Friedrich. A razão na história. Introdução à filosofia da história universal. Tradução de Artur Morão. Lisboa: Edições 70, 1995.

HERNÁNDEZ, Lissette Pérez. Democracia sin estándares. El poder en Cuba y Venezuela. In: PASTOR, Roberto Viciano (Ed.). Estudios sobre el nuevo constitucionalismo latinoamericano. Valencia: Tirant lo Blanch, 2012.

HIDALGO, Paulina del Consuelo Mosquera. La participación ciudadana a través de los mecanismos de democracia directa en los procesos de reforma constitucional en la legislación ecuatoriana. 2014. Tesis (previa a la obtención del título de abogada) Facultad de Jurisprudencia, ciencias políticas y sociales de la Universidad Central del Ecuador, Quito, 2014. Disponível em: <http://www.dspace.uce.edu.ec/handle/ 25000/3265>. Acesso em: 22 nov. 2015.

HILL, Jonathan. Comparative law: law reform and legal theory. Oxford Journal of Legal Studies, v. 9, n. 1, p. 101-115, Spring 1989. Disponível em: <http://www.jstor. org/stable/pdf/764340.pdf? =1470168502182>. Acesso em: $1^{\circ}$ ago. 2016. 
HIRSCH, Joachim. Teoria materialista do Estado. Processos de transformação do sistema capitalista de Estados. Tradução de Luciano Cavini Martorano. São Paulo: Revan, 2010.

HIRSCHL, Ran. A judicialização da megapolítica e o surgimento dos tribunais políticos. Tradução de Adauto Villela. In: MOREIRA, Luiz (Org.). Judicialização da política. São Paulo: 22 Editorial, 2012.

HIRSCHL, Ran. The judicialization of mega-politics and the rise of political courts. Annual Review of Political Science, v. 11, p. 01-44, 2008, Disponível em: <https://a1papers.ssrn.com/sol3/papers.cfm?abstract_id=1138008\&download=yes >. Acesso em: 10 out. 2016.

HIRSCHL, Ran. Towards juristocracy: the origins and consequences of the new constitutionalism. Cambridge: Harvard University Press, 2004.

HOBSBAWN, Eric J. A era das revoluções 1789-1848. Tradução de Maria Tereza Lopes Teixeira e Marcos Penchel. 17. ed. São Paulo: Paz e Terra, 2006.

HOBSBAWN, Eric. Era dos extremos: o breve século XX - 1914-1991. 2. ed. Tradução de Marcos Santarrita. São Paulo: Companhia das Letras, 1995.

HOCHSTETLER, Kathryn. Repensando el presidencialismo: desafios y caídas presidenciales en el cono sur. América Latina Hoy, v. 49, p. 51-72, 2008. Disponível em: <http://gredos.usal.es/jspui/handle/10366/72667>. Acesso em: 18 out. 2016.

HUSA, Jaakko. About the methodology of comparative law - some comments concerning the Wonderland... Maastricht: Maastricht Faculty of Law Working Paper, 2007.

IBARRA, Hernán. Visión histórico política de la Constitución del 2008. Quito: Centro Andino de Acción Popular (CAAP), 2010.

JACKSON, Vicki C.; TUSHNET, Mark. Defining the field of comparative constitutional law. Westport, CT: Praeger, 2002.

JÁCOME, Francine. Venezuela: old successes, new constraints on learning. In: MCCOY, Jennifer L. (Ed.). Political learning and redemocratization in Latin 
America. Do politicians learn from political crises? Miami: North-South Center Press/University of Miami, 1999.

JANSEN, Nils. Comparative law and comparative knowledge. In: REIMAN, Mathias; ZIMMERMANN, Reinhard (Eds.). The Oxford handbook of comparative law. New York: Oxford University Press, 2006.

JARA, Felipe Hevia de la. La iniciativa legislativa popular en America Latina. Convergencia - Revista de Ciencias Sociales, Universidad Autónoma del Estado de México, n. 52, p. 155-186, enero-abr. 2010. Disponível em: <http://convergencia.uaemex.mx/article/view/1184/1679>. Acesso em: 17 out. 2016.

JELLINEK, Georg. Teoría general del Estado. Tradução de Fernando de los Ríos. México: Fondo de Cultura Económica, 2004.

JUSTIÇA GLOBAL. A Vale é nossa: plebiscito popular decide sobre anulação do leilão da Companhia Vale do Rio Doce. Rio de Janeiro, 27 ago. 2007. Disponível em: $<$ http://www.global.org.br/blog/a-vale-e-nossa-plebiscito-popular-decide-sobreanulacao-do-leilao-da-companhia-vale-do-rio-doce/>. Acesso em: 24 set. 2016.

KECK, Margaret K. PT - a lógica da diferença. O Partido dos Trabalhadores na construção da democracia. Tradução de Maria Lucia Montes. São Paulo: Ática, 1991.

KELSEN, Hans. A democracia. Tradução de Ivone C. Benedetti, Jefferson L. Camargo, Marcelo B. Cipolla e Vera Barkow. São Paulo: Martins Fontes, 2000.

KELSEN, Hans. Teoria geral do direito e do Estado. Tradução de Luís Carlos Borges. 4. ed. São Paulo: Martins Fontes, 2005.

KENNEDY, David. The methods and the politics. In: LEGRAND, Pierre; MUNDAY, Roderick (Eds.). Comparative legal studies: traditions and transitions. Cambridge: Cambridge University Press, 2003, p. 346. Disponível em: <http://www.law.harvard. edu/faculty/dkennedy/publications/DKennedy_TheMethodsandThePolitics.pdf $>$. Acesso em: 28 jul. 2016.

KHAN, Michael. Freud básico. Pensamentos psicanalíticos para o século XXI. Rio de Janeiro: Civilização Brasileira, 2003. 
KINZO, Maria d'Alva G. Oposição e autoritarismo: gênese e trajetória do MDB (1966-1979). Tradução de Heloisa Perrone Attuy. São Paulo: Vértice, 1988.

KIRCHGÄSSNER, Gebhard. Direct democracy: obstacle to reform? Constitutional Political Economy, v. 19, n. 2, p. 81-93, June 2008. Disponível em: $<$ http://link.springer.com/article/10.1007\%2Fs 10602-008-9039-3\#page-2〉. Acesso em: 25 jan. 2015.

KORNBLITH, Miriam. Agenda de reformas y crisis sociopolitica en Venezuela: una dificil combinación. II Congreso Internacional del CLAD sobre la reforma del Estado y de la Administración Pública, Isla de Margarita, Venezuela, p. 01-24, 14-18 oct. 1997. Disponível em: 〈http://siare.clad.org/fulltext/0032254.pdf〉. Acesso em: 07 set. 2016.

KORNBLITH, Miriam. Las elecciones presidenciales en Venezuela: de una democracia representativa a un régimen autoritario electoral. Desafíos, Bogotá, v. 14, p. 115-152, enero-jun. 2006.

KORNBLITH, Miriam. Revocatoria del mandato presidencial en Venezuela: definición y puesta en práctica. In: LISSIDINI, Alicia; WELP, Yanina; ZOVATTO, Daniel (Orgs.). Democracias en movimiento: mecanismos de democracia directa y participativa en América Latina. Ciudad de México: Universidad Nacional Autónoma de México, 2014.

LAINFORMACION.COM. La Constitución española, la más virgen de Europa: ni se mira ni se toca. Madrid, 19 dic. 2016. Disponível em: $<$ http://www.lainformacion.com/ espana/la-constitucion-espanola-la-mas-virgen-de-europa-ni-se-mira-ni-setoca_QiR3JG0tenMNaTNlrRqb24/>. Acesso em: 10 out. 2016.

LALANDER, Rickard. The impeachment of Carlos Andrés Pérez and the collapse of Venezuelan partyarchy. In: LLANOS, Mariana; MARSTEINTREDET, Leiv (Eds.). Presidential breakdowns in Latin America: causes and outcomes of executive instability in developing democracies. New York: Palgrave Macmillan, 2010. 
LAMOUNIER, Bolívar. Partidos e utopias: o Brasil no limiar dos anos 90. São Paulo: Loyola, 1989.

LANDER, Edgardo. El referéndum sobre la reforma constitucional el proceso político en Venezuela entra en una encrucijada crítica. Revista Venezuelana de Economia y Ciencia Sociales, Caracas, v. 14, n. 2, p. 133-166, mayo-agosto 2008.

LANDER, Luis E. La insurrección de los gerentes: PDVSA y el gobierno de Chávez. Revista Venezolana de Economia y Ciencias Sociales, Universidad Central de Venezuela, Caracas, v. 10, n. 2, p. 13-32, mayo-agosto, 2004.

LEAL, Victor Nunes. Problemas de direito público e outros problemas. Brasília: Ministério da Justiça, 1997. v. 2.

LEDUC, Lawrence. The politics of direct democracy. Referendum in global perspective. Toronto: Broadview press, 2003.

LEIB, Ethan J. Can direct democracy be made deliberative? Buffalo Law Review, v. 54, p. $\quad$ 903-925, $2006 . \quad$ Disponível em: $<$ http://ir.lawnet.fordham.edu/cgi/viewcontent.cgi? article $=1079 \&$ context=facultyscholarship $>$. Acesso em: 12 dez. 2014.

LEMBO, Cláudio. Observações sobre o impeachment, CEPES, 29 ago. 2016. Disponível em: <http://cepes.org.br/site/index.php/2016/08/29/observacoes-sobre-oimpeachment/>. Acesso em: 20 out. 2016.

LEMBO, Cláudio. Participação política e assistência simples. Rio de Janeiro: Forense Universitária, 1991.

LEWIS, Daniel C. Direct democracy and minority rights. A critical assessment of the tyranny of the majority in the american states. New York: Routledge, 2013.

LIJPHART, Arend. Las democracias contemporáneas. Un estudio comparativo. Tradução de Elena de Grau. Barcelona: Ariel, 1991.

LIJPHART, Arend. Modelos de democracia. Formas de gobierno y resultados en treinta y seis países. Tradução de Carme Castellnou. Barcelona: Ariel, 2008. 
LINDNER, Julia. Lewandowski diz que impeachment de Dilma foi um "tropeço na democracia”. Estadão, São Paulo, 28 set. 2016. Disponível em: $<$ http://politica.estadao.com.br/noticias/geral,lewandowski-diz-que-impeachment-dedilma-foi-um-tropeco-na-democracia,10000078768>. Acesso em: 20 out. 2016.

LINERA, Miguel Ángel Presno. La democracia directa y la falacia de sus riesgos. In: GUTIÉRREZ, Ignacio Gutiérrez (Coord.). La democracia indignada: tensiones entre voluntad popular y representación política. Granada: Comares, 2014.

LINZ, Juan J.; STEPAN, Alfred. A transição e consolidação da democracia: a experiência do sul da Europa e da América do Sul. Tradução de Patrícia de Queiroz Carvalho Zimbres. São Paulo: Paz e Terra, 1999.

LISSIDINI, Alicia. Democracia directa en latinoamérica: entre la delegación y la participación. Buenos Aires: Consejo Latinoamericano de Ciencias Sociales CLACSO, 2011.

LISSIDINI, Alicia. Democracia directa en Venezuela: ¿participación controlada? In: WELP, Yanina; SERDÜLT, Uwe (Coords.). Armas de doble filo. La participación ciudadana en la encrucijada. Buenos Aires: Prometeo Libros, 2008.

LOEWENSTEIN, Karl. Brazil under Vargas. New York: Macmillan Company, 1942.

LOEWENSTEIN, Karl. Teoría de la constitución. Tradução de Alfredo Gallego Anabitarte. Barcelona: Editorial Ariel, 1986.

LÓPEZ A., Adrián; CELIS, Paula Cubillos. Análisis del referéndum Constitucional 2008 en Ecuador. Íconos - Revista de Ciencias Sociales, Quito, n. 33, p. 13-20, enero 2009.

LÓPEZ, Carlos Ramírez. El fruto del árbol envenenado: la constituyente como excusa para matar el Estado democrático. Bloomington: Palibrio, 2015.

LOSURDO, Domenico. Democracia ou bonapartismo. Triunfo e decadência do sufrágio universal. Tradução de Luiz Sérgio Henriques. Rio de Janeiro: Editora UFRJ/Unesp, 2004. 
LÖWY, Michael. Ideologias e ciência social: elementos para uma análise marxista. São Paulo: Cortez, 2010.

LUKÁCS, Georg. El asalto a la razón. La trayectoria del irracionalismo desde Schelling hasta Hitler. México: Fondo de Cultura Económica, 1959.

LUQUE, Luis Aguiar de. Democracia directa y derecho constitucional. Madrid: Edersa, 1977.

LUQUE, Luis Aguiar de; PICÓN, Fernando Reviriego. Implicaciones constitucionales del giro político en algunos países iberoamericanos (2005-2007). Cuadernos de Derecho Público, n. 27, p. 227-293, enero-abr. 2006. Disponível em: $<$ http://revistasonline.inap.es/index.php?journal=CDP\&page=article\&op=viewFile \&p ath\%5B\%5D=779\&path\%5B\%5D=834>. Acesso em: 29 ago. 2016.

LVOVICH, Daniel. Actitudes sociales y dictaduras: las historiografías española y argentina en perspectiva comparada. In: AGUILA, Gabriela; ALONSO, Luciano (Coords.). Procesos represivos y actitudes sociales: entre la España franquista y las dictaduras del Cono Sur. Buenos Aires: Prometeo Libros, 2013.

MACÍAS, Antonio Ibáñez. El derecho constitucional a participar y la participación ciudadana local. Madrid: Difusión, 2007.

MACÍAS, Antonio Ibáñez. El referéndum local en España: régimen jurídico. Cádiz: Universidad de Cádiz, 2005.

MACPHERSON, C. B. A democracia liberal. Origens e evolução. Tradução de Nathanael C. Caixeiro. Rio de Janeiro: Zahar, 1978.

MADUZ, Linda. Direct democracy. Living Reviews in Democracy, ETH Zurich and University of Zurich, v. 2, 2010.

MAIA, Rousiley Celi Moreira. A dinâmica da deliberação: indicadores do debate midiado sobre o referendo do desarmamento. Contemporanea, v. 4, n. 2, p. 13-44, dez. $2006 . \quad$ Disponível em: <http://www.portalseer.ufba.br/index.php/contemporaneaposcom/ article/viewFile/3496/2552>. Acesso em: 05 jan. 2015. 
MAINWARING, Scott P. Sistemas partidários em novas democracias - o caso do Brasil. Tradução de Vera Pereira. Porto Alegre: Mercado Aberto; São Paulo: FGV, 2001.

MAINWARING, Scott P. The representation in the Andes. Journal of Democracy, v. 17, n. 3, p. 13-27, July 2006. Disponível em: $<$ http://scholar.harvard.edu/files/levitsky/

files/mainwaring 2006.pdf>. Acesso em: 10 out. 2016.

MAIR, Peter. Ruling the void. The hollowing of Western Democracy. Verso: London, 2013.

MALBERG, R. Carré. Teoría general del Estado. Tradução de José Lión Depetre. México: Fondo de Cultura Económica, 2001.

MANFRINI, Sandra. FHC fechou três acordos com o FMI; confira o histórico. Folha de S.Paulo, São Paulo, 07 ago. 2002. Folha Economia. Disponível em: $<$ http://www1.folha.uol.com.br/folha/dinheiro/ult91u53074.shtml>. Acesso em: 23 set. 2016.

MANIN, Bernard. Los principios del gobierno representativo. Tradução de Fernando Vallespín. Alianza: Madrid, 2006.

MANO, Maíra Kubíl. Justiça reconhece fraude na privatização da Vale do Rio Doce. Revista Fórum, São Paulo, 12 jun. 2013. Disponível em: <http://www.revistaforum. com.br/2013/06/12/justica-reconhece-fraude-na-privatizacao-da-vale-do-rio-doce/> . Acesso em: 24 set. 2016.

MARCO, Jorge. Limpieza política en España. Insurrección, guerra civil y postguerra (1936-1953). In: AGUILA, Gabriela; ALONSO, Luciano (Coords.). Procesos represivos y actitudes sociales: entre la España franquista y las dictaduras del Cono Sur. Buenos Aires: Prometeo Libros, 2013.

MARIÁTEGUI, José Carlos. Por um socialismo indo-americano: ensaios escolhidos. Seleção e introdução de Michael Löwe. Tradução de Luiz Sérgio Henriques. 2. ed. Rio de Janeiro: Editora da UFRJ, 2011. 
MARINGONI, Gilberto. A revolução venezuelana. São Paulo: Editora da Unesp, 2008.

MARTÍN, Joan Ridao i. La crisis de la representación en España y los déficits de participación política: el limitado alcance de la institución referendaria. Quaestio Iuris, Rio de Janeiro, v. 08, n. 01, p. 212-249, 2015. Disponível em: 〈http://www.epublicacoes.uerj.br/index.php/quaestioiuris/article/view/15357/11683>. Acesso em: 10 jun. 2016.

MARTín, Maria. Abstenção é a mais alta desde 1998. El País, São Paulo, 07 out. 2014.

Disponível

em:

< http://brasil.elpais.com/brasil/2014/10/07/politica/1412713399

211493.html>. Acesso em: 22 out. 2016.

MARX, Karl. A guerra civil na França. In: MARX, Karl; ENGELS, Friedrich. Obras escolhidas. São Paulo: Alfa Omega, s/d. v. 2.

MARX, Karl. O 18 de Brumário de Luís Bonaparte. Tradução de Nélio Schneider. São Paulo: Boitempo, 2011.

MASSAL, Julie. El cambio constitucional. ¿Factor de democratización? Análisis Político, Bogotá, v. 25, n. 75, p. 29-45, mayo-agosto 2012.

MATHEUS, Xavier Reyes. Las fuentes de la legitimidad en el chavismo: ¿quién es la revolución? InterAmerican Institute for Democracy, Miami, n. 5, p. 133-155, 2013.

MATUS, Carlos. O plano como aposta. São Paulo em perspectiva, v. 4, n. 5, p. 28, out.-dez. $1991 . \quad$ Disponível em: <http://www.cgca.com.br/userfiles/file/O\%20Plano\%20

Como\%20Aposta\%20por\%20Carlos\%20Matus.pdf>. Acesso em: 20 nov. 2016.

MAYA, Margarita López. Del viernes negro al referendo revocatorio. 2. ed. Caracas: Alfadil, 2006.

MAYA, Margarita López. Venezuela entre incertidumbres y sorpresas. Nueva Sociedad, n. 235, p. 05, sept.-oct. 2011. Disponível em: $<$ http://nuso.org/articulo/venezuela-entre-incertidumbres-y-sorpresas/>. Acesso em: 10 set. 2016. 
MAYA, Margarita López. Venezuela 2001-2004: actores y estrategias en la lucha hegemónica. Consejo Latinoamericano de Ciencias Sociales (CLACSO), p. 23-48, 2006. Disponível em: <http://biblioteca.clacso.edu.ar/clacso/gt/20101020012743/ 2PICuno.pdf>. Acesso em: 20 mar. 2016.

MAYA, Margarita Lopez. Venezuela: Hugo Chávez y el bolivarianismo. Revista Venezoelana de Economia y Ciencia Sociales, v. 14, n. 3, p. 55-82, sept.-dic., 2008.

MAYA, Margarita López. Venezuela después del Caracazo: formas de la protesta en un contexto desinstitucionalizado. Working Paper, n. 287, p. 05, July 2001, p. 05. Disponível em: <https://kellogg.nd.edu/publications/workingpapers/WPS/287.pdf>. Acesso em: 10 mar. 2016.

MAYA, Margarita López; LANDER, Luis E. El socialismo rentista de Venezuela ante la caída de los precios petroleros internacionais. Cuadernos del Cendes, año 26, n. 71, p. 67-87, mayo-agosto 2009. Disponível em: <http://www.redalyc.org/articulo.oa?id $=40311835004>$. Acesso em: 14 set. 2016.

MAYA, Margarita Lopez; LANDER, Luis E. Referendo sobre la propuesta de reforma constitucional: ¿punto de inflexión en el proceso bolivariano? Revista Venezolana de Economía y Ciencias Sociales, Caracas, v. 14, n. 2, p. 195215 , agosto 2008.

Disponível em: $<$ http://www.scielo.org.ve/scielo.php?script=sci_arttext\&pid=S131564112008000200011>. Acesso em: 12 maio 2016.

MAYA, Margarita López; LANDER, Luis E. Venezuela 2009: en medio de dificultades avanza el modelo socialista del presidente Chávez. Revista de Ciencia Política, Pontificia Universidad Católica de Chile, Santiago, v. 30, n. 2, p. 537-553, 2010. Disponível em: <http://www.revistacienciapolitica.cl/rcp/wpcontent/uploads/2013/09/18_vol_30_2.pdf>. Acesso em: 09 jun. 2016.

MCCOY, Jennifer. O referendo na Venezuela: um ato em um drama inacabado. Novos Estudos - CEBRAP, São Paulo, n. 72, p. 02, jul. 2005. Disponível em: <http://www.scielo.br/scielo.php?script=sci_arttext\&pid=S010133002005000200001>. Acesso em: 30 abr. 2016.

MEIRELlES, Renato. A classe C e a crise. Revista Carta Capital, São Paulo, $1^{\circ}$ abr. 2016. Disponível em: 〈http://www.cartacapital.com.br/politica/a-classe-c-e-a-crise〉. 
Acesso em: 08 abr. 2016.

MELCHIORI, Cíntia Ebner. Participação e representação política: a iniciativa popular de lei e o caso do movimento de combate à corrupção eleitoral. 2011. Dissertação (Mestrado em Gestão de Políticas Públicas) - Escola de Administração de Empresas de São Paulo da Fundação Getulio Vargas, São Paulo, 2011. Disponível em: 〈https://bibliotecadigital.fgv.br/dspace/handle/10438/8664>. Acesso em: 12 jan. 2015.

MELO, Mônica de. Plebiscito, referendo e iniciativa popular. Mecanismos constitucionais de participação popular. Porto Alegre: Sergio Antonio Fabris Editor, 2000.

MELO, Oswaldo Aranha Bandeira de. Princípios gerais de direito administrativo. São Paulo: Malheiros, 2007. v. I.

MENDES, Flávio da Silva. Estado e direitos sociais na Venezuela (1958-1998): da expansão petroleira ao "desmanche". Perseu, ano 6, n. 8, p. 290-313, 2012. Disponível em: <http://novo.fpabramo.org.br/sites/default/files/7.perseu8.mendes_0.pdf>. Acesso em: 24 mar. 2016.

MENDES, Renato. Entrevista: Ricardo Gebrim. Disponível em: <http://www.correiocidadania.com.br/antigo/ed311/geral2.htm>. Acesso em: 24 set. 2016.

MICHILES, Carlos et al. Cidadão constituinte: a saga das emendas populares. Rio de Janeiro: Paz e Terra, 1989.

MIGUEL, Luis Felipe. Democracia e representação: territórios em disputa. São Paulo: Editora da Unesp, 2013.

MIRANDA, Jorge. Sobre o direito constitucional comparado. Revista de Direito Constitucional e Internacional, v. 55, ano 14, abr.-jun., 2006.

MIRKINE-GUETZÉVITCH, Boris. Les méthodes d'étude du droit constitutionnel comparé. Revue Internationale de Droit Comparé, v. 1, n. 4, p. 397-417, oct.-déc. 1949. 
MOECKLI, Daniel. Of minarets and foreign criminals: Swiss direct democracy and human rights. Human Rights Law Review, v. 11, n. 4, Dec. 2011, p. 03. Disponível em:

<http://www.zora.uzh.ch/51466/1/Moeckli_Human_Rights_Law_Review_4_2011.pd f>. Acesso em: 20 dez. 2014.

MOISÉS, José Álvaro. Cidadania e participação: ensaio sobre o plebiscito, o referendo e a iniciativa popular na nova Constituição. São Paulo: Marco Zero, 1990.

MOLINA, José E.; PÉREZ, Carmen B. Radical change at the ballot box: causes and consequences of electoral behavior in Venezuela's 2000 elections. Latin American Politics and Society, University of Miami, v. 46, n. 1, p. 103-134, Spring 2004.

MOMMER, Bernard. Venezuela: un nuevo marco legal e institucional petrolero. Revista Venezolana de Economía y Ciencias Sociales, v. 8, n. 2, p. 201-207, mayoagosto 2003. Disponível em: <http://biblioteca.clacso.edu.ar/ar/libros/venezuela/ rvecs/mommer.pdf >. Acesso em: 10 ago. 2016.

MONTESQUIEU, Charles-Louis de Secondat. O espírito das leis. Tradução de Cristina Murachco. São Paulo: Martins Fontes, 2005.

MORALES, Angel Garrorena. Teoría y práctica española del referéndum. Anales de la Universidad de Murcia (Derecho), v. XXXI, n. 3-4, p. 79-108,1977.

MOREL, Laurence. Le référendum: état des recherches. Revue Française de Science Politique, v. 42, n. 5, p. 835-864, 1992. Disponível em: <http://persee.fr/web/revues/ home/prescript/article/rfsp_0035-2950_1992_num_42_5_404346>. Acesso em: 12 jan. 2015.

MOTTA, Rodrigo Patto Sá. Introdução à história dos partidos políticos brasileiros. 2. ed. Belo Horizonte: Editora da UFMG, 2008.

MUELLER, Dennis. C. Constitutional democracy. New York: Oxford University Press, 1996.

MÜLLER, Friedrich. Quem é o povo: a questão fundamental da democracia. 5. ed. São Paulo: Revista dos Tribunais, 2010. 
MUNCK, Gerardo L; LEFF, Carol Skalnik. Modes of transition and democratization: South America and Eastern Europe in comparative perspective. Comparative Politics, v. 29, n. 3, p. 343-362, Apr. 1997. Disponível em: <http://www.jstor.org/ stable/422125?seq=1\#page_scan_tab_contents>. Acesso em: 23 out. 2016.

MURO, Ignacio Torres. Encuesta sobre el referéndum. UNED, Teoría y Realidad Constitucional, n. 30, p. 11-56, 2012. Disponível em: <http://revistas.uned.es/ index.php/TRC/issue/view/514>. Acesso em: 18 jul. 2016.

NÁRDIZ, Alfredo Ramírez. Análisis comparado de la práctica del referendo nacional en España y Colombia desde la aprobación de las constituciones de 1978 y 1991. Revista Amauta, Universidad del Atlántico, Barranquilla (Colômbia), n. 25, p. 23-38, enero-jun. 2015. Disponível em: <http://investigaciones.uniatlantico.edu.co/revistas/ index.php/Amauta/article/view/1274>. Acesso em: 11 jul. 2016.

NÁRDIZ, Alfredo Ramírez. Democracia participativa: la democracia participativa como profundización en la democracia. Valencia: Tirant lo Blanch, 2010.

NÁRDIZ, Alfredo Ramírez. Democracia participativa. La experiencia española contemporánea. Tesis Doctorales, Universidad de Alicante. 2009. Disponível: $\langle$ http://www.cervantesvirtual.com/buscador/?q=Alfredo+Ramirez+Nárdiz〉. Acesso em: 15 set. 2016.

NÁRDIZ, Alfredo Ramírez. El debate en torno a los mecanismos de democracia participativa durante el proceso constituyente español. Cuadernos Constitucionales de la Cátedra Fadrique Furió Ceriol, n. 67/68, p. 167-178, 2009. Disponível em: <https://dialnet.unirioja.es/servlet/articulo?codigo=3903171>. Acesso em: 05 jul. 2016.

NÁRDIZ, Afredo Ramírez. Estudio comparado de la regulación infraconstitucional nacional de la democracia participativa en Colombia y España. Justicia Juris, v. 10, n. 1, p. 74-86, enero-jun. 2014. Disponível em: <http://ojs.uac.edu.co/index.php/justiciajuris/article/view/301>. Acesso em: 16 out. 2016.

NICOLAU, Jairo. Eleições no Brasil: do Império aos dias atuais. Rio de Janeiro: Zahar, 2012. 
NICOLAU, Jairo Marconi. As distorções na representação dos estados na Câmara dos Deputados brasileira. Dados, Rio de Janeiro, v. 40, n. 3, p. 04, 1997. Disponível em: $<$ http://www.scielo.br/scielo.php?script=sci_arttext\&pid=S001152581997000300006>. Acesso em: 02 jan. 2016.

NINO, Carlos Santiago. The constitution of deliberative democracy. New Haven: Yale University Press, 1996.

O ESTADO DE S. PAULO. Na Constituição, a raiz da crise. São Paulo, 20 set. 2015. Caderno Opinião. Disponível em: <http://opiniao.estadao.com.br/noticias/geral,naconstituicao--a-raiz-da-crise, 1765466>. Acesso em: 10 jan. 2015.

OCHOA, David. Debate sobre el proyecto de enmiendas constitucionales. In: DELGADO, Ana María; ZAIDÁN, Salim (Eds.). Debate sobre el proyecto de enmiendas constitucionales. Quito: [s.n.], 2014.

O’DONNELL, Guillermo. Democracia delegativa. Journal of Democracy en Espanõl, p. 07-23. Disponível em: <http://www.plataformademocratica.org/Publicacoes/ 11566.pdf>. Acesso em: 20 ago. 2016.

OLIVEIRA, Valéria de. Plebiscito sobre dívida não tem resultado prático, reconhece CNBB. Folha de S.Paulo, São Paulo, 02 set. 2000. Folha Política. Disponível em: <http://www1.folha.uol.com.br/folha/brasil/ult96u5619.shtml>. Acesso em: 22 set. 2016.

OLMO, Guillermo D. La Constitución solo la cambia Europa. ABC.es, Madrid, 29 agosto 2011. Disponível em: <http://www.abc.es/20110825/espana/abci-constitucionsolo-cambia-europa-201108250914.html>. Acesso em: 10 out. 2016.

ORTEGA, Rafaela Teresa Quintero. Iniciativa legislativa popular en España: aspectos normativos e incidencia práctica. Ars Iuris Salmanticensis, v. 2, p. 137-162, jun. 2014. Disponível em: <http://revistas.usal.es/index.php/ais/article/view/11974>. Acesso em: 20 set. 2016.

ORTIZ, Andréz. Populismo y transnacionalidad. Una hipótesis sobre el liderazgo de Chávez y Correa. Ecuador Debate, Quito, n. 73, p. 63-76, abr. 2008. 
OSTROGORSKI, Moisei. La democracia y los partidos políticos. Tradução de Antonio Lastra e Andrés Alonso Martos. Madrid: Editorial Trotta, 2008.

OTTO, Ignacio de. Derecho constitucional: sistemas e fuentes. Barcelona: Ariel, 1988.

OYARTE, Rafael. Derecho constitucional ecuatoriano y comparado. Quito: Corporación de Estudios y Publicaciones (CEP), 2014.

OYARTE, Rafael. La Asamblea Constituyente. Foro: revista de derecho, Quito, Universidad Andina Simón Bolívar (UASB), n. 7, p. 33-49, 2007. Disponível em: <http://repositorio.uasb.edu.ec/

handle/10644/1977>. Acesso em: 24 jul. 2016.

PACERA, Cosimina G. Pellegrino. Una introducción al estudio del referendo como mecanismo de participación ciudadana en la Constitución de 1999. In: ARISMENDÍ, Alfredo; ORTIZ, Jesús Caballero (Coords.). El derecho público a comienzos del siglo XXI. Estudios en homenaje al profesor Allan R. Brewer Carías. Madrid: Civitas Ediciones, 2003. t. I.

PACHANO, Simón. Democracia a la medida: la caída de Bucaram no debe sorprender. Iconos Revista de Ciencias Sociales, FLACSO-Equador, n. 1, feb.-abr., p. 07-13, $1997 . \quad$ Disponível em: < http://revistas.flacsoandes.edu.ec/iconos/article/view/468>. Acesso em: 26 jul. 2016.

PACHANO, Simón. Democracia directa en Ecuador. In: LISSIDINI, Alicia; WELP, Yanina; ZOVATTO, Daniel (Coords.). Democracia directa en latinoamérica. Buenos Aires: Prometeo Libros, 2008.

PACHANO, Simón. La trama de Penélope. Procesos políticos e instituciones en el Ecuador. Quito: FLACSO, 2007.

PANAMÁ. Constitución Política de la República de Panamá (1972). Disponível em: $\langle$ http://www.asamblea.gob.pa/cep/contitucion_del_1972_reforma.pdf $>$. Acesso em: 20 ago. 2016. 
PANIAGUA, Enrique Linde; LERA, Miguel Herrero. El referéndum de las leyes fundamentales al anteproyecto de constitución. Revista de Estudos Políticos (Nueva Epoca), n. 2, p. 87-106, marzo-abr. 1978. Disponível em: <http://www.cepc.gob.es/ publicaciones/revistas/revistaselectronicas?IDR=3\&IDN=162\&IDA=15671>. A Acesso em: 09 jun. 2016.

PAPADOPOULOS, Yannis. Citizenship through direct democracy? The "broken promises" of empowerment. In: CROUCH, Colin; EDER, Klaus; TAMBINI, Damian (Eds.). Citizenship, markets and the state. New York: Oxford University Press, 2001.

PARDO, Ignacio de Otto y. La Constitución de 1978 en la historia constitucional española. In: SARASOLA, Ignacio Fernández (Coord.). Ignacio de Otto. Obras completas. Madrid-Oviedo: CEPC-Universidad de Oviedo, 2010.

PASTOR, Juan A. Santamaría. Comentários a la Constitución. In: FALA, Garrido Fernando (Ed.). Comentários a la Constitución. 2. ed. Madrid: Editorial Civitas, 1985.

PASTOR, Roberto Viciano; DALMAU, Rubén Martínez. Cambio político y proceso constituyente en Venezuela (1998-2000). Valencia: Tirant lo Blanch, 2001.

PATEMAN, Carole. Participation and democratic theory. New York: Cambridge University Press, 1999.

PATERNA, María Jesús Larios. La participación ciudadana en la elaboración de la ley. Madrid: Congreso de los Diputados, 2003.

PAULINO NETO, Fernando. Vale é vendida por R\$ 3,3 bi e ágio de 20\%. Folha de S.Paulo, São Paulo, 07 maio 1997. Folha Brasil. Disponível em: <http://www1.folha.uol.com.br/fsp/brasil/fc070513.htm>. Acesso em: 24 set. 2016.

PAZ, Rosangela Dias Oliveira da. Fundo Nacional de Moradia Popular: marco histórico de participação da União dos Movimentos de Moradia de São Paulo. 1996. Dissertação (Mestrado em Serviço Social) - Faculdade de Serviço Social da Pontifícia Universidade Católica de São Paulo, São Paulo, 1996, p. 122-123. Disponível em: <www.unmp.org/index.php?option=com_docman\&task=doc_download\&gid=181\&lt emid=95>. Acesso em: 27 set. 2016. 
PEGORARO, Lucio. El método en el derecho constitucional: la perspectiva desde el derecho comparado. Revista de Estudios Políticos (Nueva Época), n. 112, p. 09-26, abr.-jun. 2001.

POGUNTKE, Thomas. WEBB, Paul. The presidentialization of politics in democratic societies. In: POGUNTKE, Thomas; WEBB, Paul (Eds). The presidentialization of politics: a comparative study of modern democracies. New York: Oxford University Press, 2009.

PELAYO, Garcia. Derecho constitucional comparado. Madrid: Revista de Occidente, 1961.

PERDOMO, Rogelio Pérez. Judicialization and regime transformation: the Venezuelan Supreme Court. In: SIEDER, Rachel; SCHJOLDEN, Line; ANGELL, Alan (Eds.). The judicialization of politics in Latin America. New York: Palgrave Macmillan, 2005.

PÉREZ-LIÑAN, Aníbal. Instituciones, coaliciones callejeras e inestabilidad política: perspectivas teóricas sobre las crisis presidenciales. América Latina Hoy, n. 49, p. 105-126, 2008. Disponível em: <http://revistas.usal.es/index.php/11302887/article/view/1352>. Acesso em: 18 out. 2016.

PÉREZ-LIÑAN, Anibal. Juicio político al presidente y nueva inestabilidad política en América Latina. Tradução de Silva Villegas. Buenos Aires: Fondo de Cultura Económica, 2009.

PÉREZ-LIÑAN, Aníbal. ¿Juicio político o golpe legislativo? Sobre las crisis constitucionales en los años noventa. América Latina Hoy, n. 26, p. 67-74, dic. 2000.

PESANTES, Hernán Salgado. El proceso constituyente de Ecuador. Algunas reflexiones. In: GARZA, José María Serna de la (Coord.). Procesos constituyentes contemporáneos en América Latina: tendencias e perspectivas. Ciudad de México: Instituto de Investigaciones Jurídicas de la UNAM, 2009.

PESANTES, Hernán Salgado. ¿Guardianes o sepultureros de la Constitución 2008 ? Primer balance de la "Corte Constitucional en transición”. Anuario Iberoamericano de Justicia Constitucional, Madrid, n. 17, p. 311-324, 2013. 
PESANTES, Hernán Salgado. Lecciones de derecho constitucional. 4. ed. Quito: Ediciones Legales, 2012.

PIERUCCI, Antônio Flávio. Ciladas da diferença. São Paulo: Editora 34, 2000.

PISARELLO, Gerardo. Constitución e governabilidad: razones de una democracia de baja intensidad. In: CAPELLA, Juan-Ramón (Ed.). Las sombras del sistema constitucional español. Madrid: Editorial Trotta, 2003.

PISARELLO, Gerardo. Procesos constituyentes: caminos para la ruptura democrática. Madri: Editorial Trotta, 2014.

PISARELLO, Gerardo. Un largo termidor. La ofensiva del constitucionalismo antidemocrático. Madrid: Editorial Trotta, 2011.

PISARELLO, Gerardo. Una reforma constitucional para la periferia europea. Revista de Economía Crítica, n. 12, p. 160-170, segundo semestre 2011. Disponível em: $<$ http://www.revistaeconomiacritica.org/sites/default/files/revistas/n12/REC12_Notas _2_Gerardo_pisarelo.pdf>. Acesso em: 13 out. 2016.

PONTES DE MIRANDA, Francisco Cavalcanti. Comentários à Constituição de 1967, com a Emenda n. 01 de 1969. São Paulo: Revista dos Tribunais, 1970.

PONTHOREAU, Marie-Claire. Le droit comparé en question(s): entre pragmatisme et outil épistemologique. Revue Internacionale de Droit Comparé, v. 57, n. 1, p. 07$27,2005$.

PORTAL DO PLANALTO. Mensagem enviada aos presidentes da Câmara dos Deputados, Henrique Eduardo Alves, e do Senado, Renan Calheiros, em 02 de julho de 2013. Brasília, 02 jul. 2013. Disponível em: <http://www2.planalto.gov.br/acompanhe-o-planalto/notas-oficiais/notasoficiais/mensagem-enviada-aos-presidentes-da-camara-dos-deputados-henriqueeduardo-alves-e-do-senado-renan-calheiros-em-02-de-julho-de-2013>. Acesso em: 22 set. 2016.

PORTO, Walter Costa. O voto no Brasil: da Colônia à $6^{\text {a }}$ República. Rio de Janeiro: Topbooks, 2002. 
POZO, Fabián. Debate sobre el proyecto de enmiendas constitucionales. OCHOA, David. Debate sobre el proyecto de enmiendas constitucionales. In: DELGADO, Ana María; ZAIDÁN, Salim (Eds.). Debate sobre el proyecto de enmiendas constitucionales. Quito: [s.n.], 2014.

PRADERA, Javier. La transición española y la democracia. Madrid: Fondo de Cultura Económica, 2014.

PRADO JÚNIOR, Caio. Evolução política do Brasil e outros estudos. 8. ed. São Paulo: Brasiliense, 1972.

PRAT, Cesareo R. Aguilera de. El uso del referéndum en la España democrática (1976-1986). Revista de Estudios Políticos (Nueva Epoca), n. 75, p. 131-163, eneromarzo 1992.

PRELOT, Marcel. Institutions politiques et droit constitutionnel. Paris: Dalloz, 1963.

PROL, Flavio Marques. PEC 241: levando justificativas a sério. Jota, 10 out. 2016. Disponível em: <http://jota.uol.com.br/pec-241-levando-justificativas-serio>. Acesso em: 10 out. 2016.

RAMOS, Dircêo Torrecillas. Autoritarismo e democracia. O exemplo constitucional espanhol. São Paulo: Editora Acadêmica, 1988.

REDE BRASIL ATUAL. Plebiscito Popular pela Constituinte da reforma política inicia a apuração de votos. São Paulo, 09 ago. 2014. Disponível em: <http://www.redebrasilatual.com.br/cidadania/2014/09/plebiscito-popular-pelaconstituinte-comeca-apuracao-de-votos-4011.html>. Acesso em: 21 set. 2016.

REIS, Daniel Aarão. A vida política: entre ditadura e democracia - da modernização conservadora ao reformismo moderado, 1960-2010. In: REIS, Daniel Aarão (Coord.). Modernização, ditadura e democracia - 1964-2010. São Paulo: Objetiva, 2014.

RÉMOND, René. O antigo regime e a revolução 1750-1815. Tradução de Frederico Pessoa de Barros. São Paulo: Cultrix, 1986.

RENFER, Irene. Democracia directa en Argentina, Uruguay y Venezuela: tres ejemplos de democracia directa en América Latina. Buenos Aires: Prometeo Libros, 2010. 
REY, Juan Carlos. La democracia venezolana y la crisis del sistema populista de conciliación. Revista de Estudios Políticos (Nueva Época), n. 74, oct.-dic., p. 533578, 1991. Disponível em: <http://www.cepc.gob.es/publicaciones/revistas/ revistaselectronicas?IDR=3\&IDN=231>. Acesso em: 08 set. 2016.

REY, Juan Carlos. El futuro de la democracia en Venezuela. Caracas: Instituto Internacional de Estudios Avanzados (IDEA), 1989.

ROYO, Javier Pérez. La reforma constitucional inviable. 2 ed. Madrid: Catarata, 2015.

ROYO, Javier Pérez. Una asignatura pendiente: la reforma de la Constitución. Revista Española de Derecho Constitucional, n. 69, año 23, p. 215-235, sept.-dic. 2003. Disponível em: <http://www.cepc.gob.es/publicaciones/revistas/revistaselectronicas?

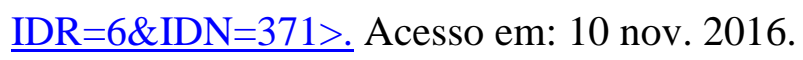

RIBEIRO, Renato Janine. A democracia. São Paulo: Publifolha, 2008.

RODRÍGUEZ, Paloma Requejo. El referéndum consultivo en España: reflexiones, críticas y algunas propuestas de futuro. Estudios de Deusto, Bilbao, v. 62, n. 1, p. 261284, enero-jun. 2014.

ROMEO, Francisco Palacios. Nuevo constitucionalismo participativo en Latinoamérica: una propuesta frente a la crisis del Behemoth Occidental. Navarra: Thomson Reuters, 2012.

ROUSSEAU, Jean-Jacques. $O$ contrato social. Princípios do direito político. Tradução de Antonio de Pádua Danesi. São Paulo: Martins Fontes, 2006.

SABATER, Jose Asensi. Constitucionalismo y derecho constitucional: materiales para una introducción. Valencia: Tirant lo Blanch, 1996.

SABINE, George H. Historia de la teoría política. Tradução de Vicente Herrero. México: Fondo de Cultura Económica, 2006.

SACCO, Rodolfo. Introdução ao direito comparado. Tradução de Véra Jacob de Fradera. São Paulo: Revista dos Tribunais, 2001. 
SÁEZ, Manuel Alcántara. Sistemas políticos de América Latina. Madrid: Tecnos, 2003. v. 1 - América del Sur.

SALAMANCA, Luis. La democracia venezolana desde 1989. De la explosión a la descentralización. Nueva Sociedad, n. 150, jul.-agosto, p. 106-111, 1997. Disponível em: 〈http://nuso.org/media/articles/downloads/2615_1.pdf〉. Acesso em: 7 set. 2016.

SALAMANCA, Luis. Venezuela. La crisis del rentismo. Nueva Sociedad, n. 131, p. 10-19, mayo-jun., 1994. Disponível em: <http://nuso.org/articulo/venezuela-la-crisisdel-rentismo/>. Acesso em: 10 set. 2016.

SANÍN, Francisco Gutiérrez; ACUÑA, Fabián. Referendos constitucionales: legitimidades redundantes en procesos de cambio constitucional en los países andinos. Análisis Político, Bogotá, v. 25, n. 75, p. 07-28, mayo-agosto 2012.

SANTAMARÍA, Ana Sofía Castellanos. Ecuador: la transformación de las reglas del juego y sus consecuencias (1998-2013). In: WELP, Yanina. SERDÜLT, Uwe. (Coords.). La dosis hace el veneno: análisis de la revocatoria del mandato en América Latina, Estados Unidos y Suiza. Quito: Consejo Nacional Electoral (CNE)/Instituto de la Democracia, 2014.

SANTAMARÍA, Ramiro Ávila. Debate sobre el proyecto de enmiendas constitucionales. In: DELGADO, Ana María; ZAIDÁN, Salim (Eds.). Debate sobre el proyecto de enmiendas constitucionales. Quito: [s.n.], 2014.

SANTAMARÍA, Ramiro Ávila. El neoconstitucionalismo transformador: el estado y el derecho en la Constitución de 2008. Quito: Abya-Yala, 2011.

SANTAMARÍA, Ramiro Ávila. La 'cesación' de la Corte Suprema de Justicia del Ecuador (2004) y el Sistema Interamericano: comentario a la admisión del reclamo por la Comisión Interamericana de Derechos Humanos. Foro - Revista de Derecho, UASB-Ecuador, Quito, n. 7, p. 265-290, 2007. Disponível em: <http://repositorio.uasb.edu.ec/ bitstream/10644/1632/1/RF-07-Jurisprudencia.pdf>. Acesso em: 25 jul. 2016.

SANTANA, Jair Eduardo. Democracia e cidadania. O referendo como instrumento de participação política. Belo Horizonte: Del Rey, 1995. 
SANTOS, Boaventura de Sousa. Renovar a teoria crítica e reinventar a emancipação social. Tradução de Mouzar Benedito. São Paulo: Boitempo, 2007.

SARAMAGO, José. Democracia e universidade. Belém: Editora da UFPA; Lisboa: Fundação José Saramago, 2013.

SARTORI, Giovanni. A teoria da democracia revisitada. 1 - O debate contemporâneo. Tradução de Ivany Picasso Batista. São Paulo: Ática, 1994.

SARTORI, Giovanni. A teoria da representação no Estado representativo moderno. Tradução de Ernesta Gaetani e Rosa Gaetani. Belo Horizonte: Revista Brasileira de Estudos Políticos, 1962.

SARTORI, Giovanni. Homo videns: televisão e pós-pensamento. Tradução de Antonio Angonese. São Paulo: Edusc, 2001.

SARTORI, Giovanni. Teoria democrática. Tradução de Francisco M. da Rocha Filho e Oswaldo Blois. São Paulo: Fundo de Cultura, 1965.

SCHILLER, Theo. Origins of direct democracy - conflict, independence, democratic transformation. Iustum Aequum Salutare, v. IX, n. 4, p. 11-25, 2013.

SCHMITT, Carl. La dictadura: desde los comienzos del pensamiento moderno de la soberanía hasta la lucha de clases proletaria. Versión de José Díaz García. Madrid: Alianza, 2007.

SCHMITT, Carl. Legalidade e legitimidade. Tradução de Tito Lívio Cruz Romão. Belo Horizonte: Del Rey, 2007.

SCHMITT, Carl. Teologia política. Tradução de Elisete Antoniuk. Belo Horizonte: Del Rey, 2006.

SCHMITT, Carl. Teoría de la constitución. Tradução de Francisco Ayala. Madrid: Alianza, 2009.

SCHWARCZ, Lilia M.; STARLING, Heloisa M. Brasil: uma biografia. São Paulo: Companhia das Letras, 2015. 
SECCO, Lincoln. As Jornadas de Junho. In: Cidades rebeldes: Passe Livre e as manifestações que tomaram as ruas do Brasil. São Paulo: Boitempo/Carta Maior, 2013.

SERRAFERO, Mario D. El “impeachment” en América Latina: Argentina, Brasil y Venezuela. Revista de Estudios Políticos (Nueva Época), n. 92, p. 137-162, abr.-jun. 1996. Disponível em: <http://www.cepc.gob.es/publicaciones/revistas/ revistaselectronicas?IDR=3\&IDN=249>. Acesso em: 20 jul. 2016.

SERRAFERO, Mario D. Flexibilización del presidencialismo en América Latina: ¿n fenómeno nuevo? Revista de Estudios Políticos (Nueva Época), Madrid, n. 163, p. 6799, enero-mar. 2014.

SETÄLÄ, Maija. Referendums in Western Europe - a wave of direct democracy? Scandinavian Political Studies, v. 22, n. 4, 1999. Disponível em: <https://tidsskriff.dk/index.php/scandinavian_political_studies/article/view/13392/ 25529>. Acesso em: 10 jan. 2015.

SGARBI, Adrian. O referendo. Rio de Janeiro: Renovar, 1999.

SHANE, Peter M. When inter-branch norms break down: of arms-for-hostages, “orderly shutdowns", presidential impeachments, and judicial 'coups'. Cornell Journal of Law and Public Policy, v. 12, n. 3, article 3, p. 503-542, 2003. Disponível em: 〈http://scholarship.law.cornell.edu/cjlpp/vol12/iss3/3 > . Acesso em: 20 out. 2016.

SIEYÈS, Emmanuel Joseph. A constituinte burguesa. Qu'est-ce que le tiers État? Tradução de Norma Azeredo. 3. ed. Rio de Janeiro: Lumen Juris, 1997.

SILVA, José Afonso da. Comentário contextual à Constituição. 7. ed. São Paulo: Malheiros, 2007.

SILVA, José Afonso da. Curso de direito constitucional positivo. São Paulo: Malheiros, 2014.

SILVA, José Afonso da. Poder constituinte e poder popular: estudos sobre a Constituição. São Paulo: Malheiros, 2002. 
SILVA, José Afonso da. Processo constitucional de formação das leis. São Paulo: Malheiros, 2008.

SILVA, José Afonso da. Um pouco de direito constitucional comparado. Três projetos de Constituição. São Paulo: Malheiros, 2009.

SILVA, Paulo Thadeu Gomes da; VARGAS, Marco Antonio Martin. Aspectos históricos da Lei Complementar 135/2010. In: CAGGIANO, Monica Herman (Coord.). Ficha Limpa. Impacto nos tribunais: tensões e confrontos. São Paulo: Revista dos Tribunais, 2014.

SINGER, André. Brasil, junho de 2013, classes e ideologias cruzadas. Novos estudos, CEBRAP, São Paulo, n. 97, p. 23-40, nov. 2013. Disponível em: <http://novosestudos.uol.com.br/v1/contents/view/1534>. Acesso em: 21 set. 2016.

SINGER, André. O critério da verdade. Folha de S.Paulo, São Paulo, 03 jan. 2015. Disponível em:

<http://www1.folha.uol.com.br/colunas/andresinger/2015/01/1569976-o-criterio-daverdade.shtml>. Acesso em: 27 mar. 2016.

SINGER, André. Os sentidos do lulismo: reforma gradual e pacto conservador. São Paulo: Companhia das Letras, 2012.

SMILDE, David. Participation, politics, and culture. Emerging fragments of Venezuela's bolivarian democracy. In: SMILDE, David; HELLINGER, Daniel (Eds.). Venezuela's bolivarian democracy: participation, politics, and culture under Chávez. London/Durham: Duke University Press, 2011.

SOARES, Alessandro. Processo de cassação do mandato parlamentar por quebra de decoro. São Paulo: Saraiva, 2014.

SOLA, Nicolas Perez. La regulación constitucional del referéndum. Jaén: Universidad de Jaén, 1994.

SOTOMAYOR, Alfonso B.; MONTES, Nery Barrientos; BUREL, Bernard et al. La ENA, una experiencia chilena de capacitación para la participación, 1971-1973. Santiago de Chile: [s.n.], 2012. 
SOUZA, Jessé. A radiografia do golpe: entenda como e por que você foi enganado. Rio de Janeiro: LeYa, 2016.

SOUZA, Hebert José de. Como se faz análise de conjuntura. 14. ed. São Paulo: Vozes, 1994.

SOUZA, Maria do Carmo Campello de. Estado e partidos políticos no Brasil 19301964. 3. ed. São Paulo: Alfa Omega, 1990.

SOUZA FILHO, Rodrigo. Gestão pública e democracia: a burocracia em questão. Rio de Janeiro: Lumen Juris, 2011.

STEBAN, Jorge de; GUERRA, Luis Lópes. Referéndum consultivo y decisión política. El país, p. 11-12, 30 jan. 1986. Disponível em: <http://elpais.com/diario/1986/01/30/opinion/507423607 850215.html>. Acesso em: 27 jul. 2016.

STEFANONI, Pablo. Estado de la democracia en Venezuela, Bolivia y Ecuador. OSAL, Buenos Aires, año XII, n. 30, p. 79-110, nov. 2011.

STOKES, Susan Carol. Re-democratización y representación en América del Sur: un balance. In: BALLETBÒ, Anna. (Ed.). La consolidación democrática en América Latina. Barcelona: Editorial Hacer, 1994.

STOKES, Susan Carol. What do policy switches tell us about democracy? In: PRZEWORSKI, Adam; STOKES, Susan Carol.; MANIN, Bernard (Eds.). Democracy, accountability and representation. New York: Cambridge University Press, 1999.

STRAYER, Joseph R. As origens medievais do estado moderno. Tradução de Carlos da Veiga Ferreira. Lisboa: Gradiva, 1986.

SUÁREZ, Lenin José Andara. Democracia participativa en la Constitución bolivariana. Cadernos de Pós-Graduação em Direito: Estudos e Documentos de Trabalho, Comissão de Pós-Graduação da Faculdade de Direito da USP, São Paulo, n. 33, p. 07, 2015. 
SVENSSON, Palle. Forms and terminology of direct democracy. Paper presented at the Conference of IPSA and ECPR, São Paulo, 2011. Disponível em <http://paperroom.ipsa.org/ papers/paper_26306.pdf>. Acesso em: $1^{\circ}$ fev. 2015.

TEJERINA, Rafael del Aguila. La transición a la democracia en España: reforma, ruptura y consenso. Revista de Estudios Políticos (Nueva Época), n. 25, p. 101-127, enero-feb. 1982.

THOMAS, Hugh. A guerra civil espanhola. Tradução de James Amado e Hélio Pólvora. Rio de Janeiro: Civilização Brasileira, 1964. v. 1.

THUSWOHL, Maurício. Mais de 3,7 milhões pedem a anulção do leilão da Vale. Carta Maior, São Paulo, 16 out. 2007. Disponível em: <http://cartamaior.com.br/?/Editoria/

Politica/Mais-de-3-7-milhoes-pedem-a-anulacao-do-leilao-da-Vale/4/13937>. Acesso em: 24 set. 2016.

TILLY, Charles. Democracia. Tradução de Raquel Weiss. Petrópolis: Vozes, 2013.

TOCQUEVILlE, Alexis de. La democracia en América. Tradução de Luis R. Cuéllar. 2. ed. México: Fondo de Cultura Económica, 2002.

TOLBERT, Caroline J. Direct democracy and institutional realignment in the American States. Political Science Quarterly, v. 118, n. 3, p. 467-489, 2003. Disponível em: <http://www.jstor.org/stable/pdf/30035784.pdf?_=1471939053488\&seq=1\#page_sca n_tab_contents>. Acesso em: 22 ago. 2016.

TOMASI, Arduino. Debate sobre el proyecto de enmiendas constitucionales. In: DELGADO, Ana María; ZAIDÁN, Salim (Eds.). Debate sobre el proyecto de enmiendas constitucionales. Quito: [s.n.], 2014.

TORRE, Carlos de la. Protesta y democracia en Ecuador: la caída de Lucio Gutiérrez. In: MAYA, Margarita López. CARRERA, Nicolás Iñigo. CALVEIRO, Pilar (Eds.). Luchas contrahegemónicas y cambios políticos recientes de América Latina. Buenos Aires: $2008 . \quad$ Disponível em: 
$\langle$ http://biblioteca.clacso.edu.ar/ar/libros/grupos/lopezma/12torre.pdf $\rangle$. Acesso em: 22 jul. 2016.

TREMINIO-SÁNCHEZ, Ilka. La reforma constitucional de Rafael Correa. El caso de la reelección presidencial en Ecuador. América Latina Hoy, Salamanca, v. 67, p. 6590, jul. 2014.

TRIBUNAL SUPREMO DE JUSTIÇA. Disponível em: < http://historico.tsj.gob.ve/decisiones/scon/junio/1173-150604-02-3215.HTM>.

Acesso em: 20 ago. 2016.

ULERI, Pier Vincenzo. Introduction. In: GALLAGHER, Michael; ULERI, Pier Vincenzo (Eds.). The referendum experience in Europe. New York: Macmillan Press, 1996.

UNGER, Roberta Mangabeira. Democracia realizada: a alternativa progressista. Tradução de Carlos Graieb, Marcio Grandchamp e Paulo César Castanheira. São Paulo: Boitempo, 1999.

UPRIMNY, Rodrigo. Las transformaciones constitucionales recientes en América Latina: tendencias e desafíos. In: GARAVITO, César Rodríguez (Coord.). El derecho en América Latina: un mapa para el pensamiento jurídico del siglo XXI. Buenos Aires: Siglo Veintiuno Editores, 2011.

URBANO, Maria Benedita Malaquias Pires. O referendo. Perfil histórico-evolutivo do instituto. Configuração jurídica do referendo em Portugal. Coimbra: Coimbra, 1998.

VALDÉS, Roberto L. Blanco. Introducción a la Constitución de 1978. Madrid: Alianza Editorial, 1998.

VALENZUELA, Arturo. Presidencias latinoamericanas interrumpidas. América Latina Hoy, v. 49, p. 15-30, 2008. Disponível em: <http://gredos.usal.es/jspui/handle/ 10366/72674>. Acesso em: 17 out. 2016.

VALIENTE, Francisco Tomás. La constitución de 1978 y la historia del constitucionalismo español. Anuario de historia del derecho español, n. 50, p. 721- 
752, 1980. Disponível em: <http://www.boe.es/publicaciones/anuarios_derecho/abrir pdf.php?id=ANU-H-1980-10072100752>. Acesso em: 02 ago. 2016.

VEGA, Pedro de. La reforma constitucional y la problematica del poder constituyente. Madrid: Tecnos, 2011.

VERDÚ, Pablo Lucas. La singularidad del proceso constituyente español. Revista de Estudios Políticos, n. 1, p. 09-27, enero-feb. 1978. Disponível em: <http://www.cepc.gob.es/gl/publicacións/revistas/revistas-

electronicas? IDR=3\&IDN=161\&IDA=15654>. Acesso em: 20 jul. 2016.

VIANNA, Luiz Werneck Vianna. Caminhos e descaminhos da revolução passiva à brasileira. Dados, Rio de Janeiro, v. 39, n. 3, 1996. Disponível em: <http://www.scielo.br/scielo.php?script=sci_arttext\&pid=S0011-

52581996000300004>. Acesso em: 23 set. 2016.

VIEJO, Raimundo; MARTÍ-COSTA, Marc; PARÉS, Marc; RESENDE, Paulo E. R.; VILAREGUT, Ricard. La participación ciudadana en la esfera pública: enfoques teórico-normativos y modelos de democracia. In: PARÉS, Marc. (Coord.). Participación y calidad democrática. Evaluando las nuevas formas de democracia participativa. Barcelona: Ariel, 2009.

VILA NOVA, Carolina. 90\% dos votantes pedem auditoria da dívida. Folha de S.Paulo, São Paulo, 14 set. 2000. Folha Brasil. Disponível em: <http://www1.folha.uol.com.br/fsp/brasil/fc1409200023.htm>. Acesso em: 21 set. 2016.

VILLALON, Pedro Cruz. El referéndum consultivo como modelo de racionalización constitucional. Revista de Estudios Políticos (Nueva Época), n. 13, p. 145-168, enerofeb. 1980 .

VILLARROYA, Joaquin Tomas. Proceso constituyente y nueva constitución. Un analisis critico. Revista de Estudios Políticos (Nueva Época), n. 10, p. 59-85, jul.agosto 1979. Disponível em: <http://www.cepc.gob.es/publicaciones/revistas/ revistaselectronicas?IDR=3\&IDN=170>. Acesso em: 21 jul. 2016. 
VILLAVERDE, João. Precarização do trabalho vem aumentando, diz Unger. Revista Exame, São Paulo, 02 maio 2015. Disponível em: $<$ http://exame.abril.com.br/economia/ precarizacao-do-trabalho-vem-aumentando-diz-unger/>. Acesso em: 23 out. 2016.

VILLEGAS, Mauricio Garcia. Constitucionalismo aspiracional: derecho, democracia y cambio social en América Latina. Análisis político, Bogotá, v. 25, n. 75, p. 89-110, mayo-agosto 2012.

VILLENA, Francisco Astarloa. La iniciativa legislativa popular en España. UNED, Teoría y Realidad Constitucional, n. 10-11, p. 273-321, 2. sem. 2002-1. sem. 2003.

VITERI, Juan Pablo Morales. De la Carta Negra al movimiento de los Forajidos: plebiscitos y referendos en Ecuador. In: WELP, Yanina; SERDÜLT, Uwe (Coords.). Armas de doble filo. La participación ciudadana en la encrucijada. Buenos Aires: Prometeo Libros, 2008.

WAGSCHAL, Uwe. Direct democracy and public policymaking. Journal of Public Policy, Cambridge University Press, v. 17, n. 2, p. 223-245, May-Aug. 1997, Disponível em: <http://www.jstor.org/stable/4007611>. Acesso em: 17 jan. 2015.

WEBER, Max. A "objetividade" do conhecimento nas ciências sociais. In: COHN, Gabriel (Org.); FERNANDES, Florestan (Coord.). Weber: sociologia. Tradução de Amélia Cohn e Gabriel Cohn. São Paulo: Ática, 2008.

WEBER, Max. Ciência e política: duas vocações. Tradução de Leonidas Hegenberg e Octany Silveira da Mota. São Paulo: Cultrix, 2011.

WEBER, Max. Economia e sociedade. Fundamentos da sociologia compreensiva. Tradução de Regis Barbosa e Karen Elsabe Barbosa. Brasília: Editora da UnB, 2004. v. 2.

WEBER, Max. Parlamentarismo e governo numa Alemanha reconstruída. Tradução de Maurício Tragtenberg. São Paulo: Abril Cultural, 1974. v. XXXVII. (Coleção Os Pensadores).

WEINGAST, Barry R. Constructing self-enforcing democracy in Spain. In: OPPENHEIMER, Joe; MORRIS, Irwin (Eds). From anarchy to democracy. Stanford: 
Stanford

Press,

2004.

Disponível

em:

$<$ http://papers.ssrn.com/sol3/papers.cfm?abstract_id=1153464>. Acesso em: $20 \mathrm{jul}$. 2016.

WELP, Yanina. El referéndum contra el status quo. Análisis de Ecuador, Venezuela, Perú y Bolivia. Diálogos Latinoamericanos, n. 16, Aarhus Universitet, p. 136-155, 2009. Disponível em: 〈http://www.redalyc.org/articulo.oa? $\mathrm{id}=16212429008>$. Acesso em: 22 nov. 2015.

WELP, Yanina. España frente el referéndum europeo: o de la democracia y sus debilidades. CONfines relacion. Internaci. Ciencia Política, Monterrey, v. 5, n. 10, p. 39-53, dic. 2009. Disponível em: 〈http://confines.mty.itesm.mx/articulos10/Welp.pdf〉. Acesso em: 16 jun. 2016.

WHYTOCK, Christopher. Legal origins, functionalism, and the future of comparative law. Bringham Young University Law Review, v. 2009, n. 6, p. 1.887, Feb., 2009.

WILliAMSON, Edwin. História da América Latina. Tradução de Patrícia Xavier. Lisboa: Edições 70, 2012.

WOOD, Ellen Meiksins. Democracia contra capitalismo: a renovação do materialismo histórico. Tradução de Paulo Cezar Castanheira. São Paulo: Boitempo, 2011.

ZAYAT, Demián. Mecanismos de participación ciudadana. In: GARGARELLA, Roberto (Coord.). La Constitución en 2020. 48 propuestas para una sociedad igualitaria. Buenos Aires: Siglo Veintiuno, 2011.

ZIBECHI, Raúl. Debajo y detrás de las grandes movilizaciones. Observatorio Social de América Latina, CLACSO, año XIV, n. 34, p. 15-35, nov. 2013. Disponível em: <http://biblioteca.clacso.edu.ar/clacso/osal/20131107012902/osal34.pdf >. Acesso em: 25 set. 2016.

ZWEIGERT, Konrad. Des solutions identiques par des voies différentes - quelques observations en matière de droit comparé. Revue Internationale de Droit Comparé, v. 18, n. 1, p. 5-18, janv.-mars 1966. 
ZWEIGERT, Konrad; KÖTZ, Hein. Introduction to comparative law. $3^{\text {rd }}$ ed. rev. Tradução de Tony Weir. Oxford: Claredon Press, 1998. 